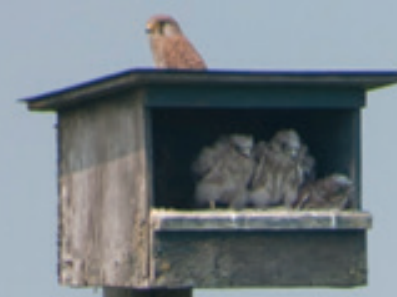

\title{
Overzicht onderzoek schadesoorten in Nederland en Leidraad beoordeling onderzoek wildschade
}





\section{Overzicht onderzoek schadesoorten in Nederland en Leidraad beoordeling onderzoek wildschade}

Ralph Buij, Dennis Lammertsma, Dick Melman

Dit onderzoek is uitgevoerd door Wageningen Environmental Research in opdracht van en gefinancierd door het Faunafonds, BIJ12, Utrecht.

Wageningen Environmental Research

Wageningen, juni 2018

Rapport 2888

ISSN 1566-7197 
Buij, R., D. Lammertsma en Th.C.P. Melman, 2018. Overzicht onderzoek schadesoorten in Nederland en Leidraad beoordeling onderzoek wildschade. Wageningen, Wageningen Environmental Research, Rapport 2888. 76 blz.; 7 fig.; 0 tab.; 191 ref.

\section{Overzicht soorten}

Van de top 10 van schadelijkste soorten in Nederland is een overzicht opgesteld van de wetenschappelijke bevindingen rond verjagen en schadereductie. Tevens is een overzicht gemaakt van aanknopingspunten voor verder onderzoek om tot een verdere beheersing van de schade te komen, waarbij tevens de duurzaamheid van de staat van instandhouding mee wordt genomen.

\section{Leidraad beoordeling onderzoek}

Een leidraad is opgesteld om wetenschappelijk onderzoek rond verjaging/schadebestrijding te kunnen beoordelen. Deze leidraad kan tevens worden gebruikt om tot een standpunt te komen over de wenselijkheid van nieuw uit te voeren onderzoek. Deze leidraad kan ook bij wijze van checklist worden gebruikt door diegenen die een verzoek tot onderzoek aan BIJ12 voorleggen.

\section{Overview of species}

Of the 'top-ten' of the most harmful species in the Netherlands, an overview has been compiled of the scientific findings concerning dislodging and damage reduction. An overview has also been made of starting points for further research in order to come to a further control of the damage, which also includes the sustainability of the species.

\section{Guideline assessment research}

A guideline has been drawn up in order to assess scientific research on the prevention of damage / damage control. This guide can also be used to come to a position on the desirability of new research to be carried out. This guide can also be used as a checklist by those who submit a request for research to $\mathrm{BIJ} 12$.

Trefwoorden: wildschade, wildverjaging, handreiking beoordeling onderzoek

Dit rapport is gratis te downloaden van https://doi.org/10.18174/453180 of op www.wur.nl/environmental-research (ga naar 'Wageningen Environmental Research' in de grijze balk onderaan). Wageningen Environmental Research verstrekt geen gedrukte exemplaren van rapporten.

2018 Wageningen Environmental Research (instituut binnen de rechtspersoon Stichting Wageningen Research), Postbus 47, 6700 AA Wageningen, T 03174807 00, www.wur.nl/environmental-research. Wageningen Environmental Research is onderdeel van Wageningen University \& Research.

- Overname, verveelvoudiging of openbaarmaking van deze uitgave is toegestaan mits met duidelijke bronvermelding.

- Overname, verveelvoudiging of openbaarmaking is niet toegestaan voor commerciële doeleinden en/of geldelijk gewin.

- Overname, verveelvoudiging of openbaarmaking is niet toegestaan voor die gedeelten van deze uitgave waarvan duidelijk is dat de auteursrechten liggen bij derden en/of zijn voorbehouden.

Wageningen Environmental Research aanvaardt geen aansprakelijkheid voor eventuele schade voortvloeiend uit het gebruik van de resultaten van dit onderzoek of de toepassing van de adviezen.

Wageningen Environmental Research Rapport 2888 | ISSN 1566-7197

Foto omslag: Een valkenkast in agrarisch landschap (met oudervogel + jongen). Het plaatsen van nestkasten in boomgaarden wordt regelmatig aangehaald als een goed middel om schade door zangvogels te verminderen. Het gaat dan niet zozeer om het predatie-effect, maar om de verschrikkende werking. Foto: Hugh Jansman. 


\section{Inhoud}

$\begin{array}{ll}\text { Woord vooraf } & 5\end{array}$

$\begin{array}{ll}\text { Samenvatting } & 7\end{array}$

$\begin{array}{ll}1 & \text { Inleiding }\end{array}$

$2 \quad$ Doelstelling $r$

$3 \quad$ Methode, uitvoering $r$

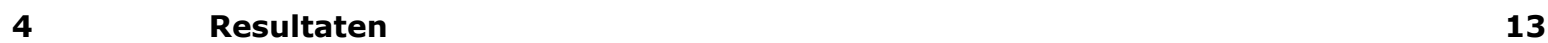

4.1 Overzicht verjagingsonderzoek van de 10 belangrijkste schadesoorten 13

4.2 Leidraad voor beoordeling onderzoek naar schade-reducerende maatregelen 55

Aanhangsel 1 Casus 'effectiviteit legselbehandeling bij ganzen' 62

$\begin{array}{ll}\text { Aanhangsel } 2 & 63\end{array}$

5 Discussie $\quad 64$

$6 \quad$ Conclusies en aanbevelingen $\quad 65$

$\begin{array}{ll}\text { Literatuur } & 66\end{array}$ 



\section{Woord vooraf}

Sinds de introductie van de huidige regeling tegemoetkoming faunaschade aan landbouwgewassen of bedrijfsmatig gehouden landbouwhuisdieren zijn onderzoeken uitgevoerd naar de toepassing van wildverjagende middelen voor het voorkomen en bestrijden van de faunaschade. In die ruim 15 jaar zijn, eerst door de ZBO Faunafonds en tegenwoordig door BIJ12 in opdracht van de provincies, circa 150 onderzoeken uitgevoerd. En kort gezegd is daar, afgezien van absoluut fysiek werende middelen zoals rasters, tot nog toe niet één verjagingsmiddel uit naar voren gekomen dat, zonder gewenning van de dieren, kon zorgen voor een effectieve en structurele vermindering van de schade. De toepassing van de uitkomsten van al deze onderzoeken in de praktijk maakt daarentegen wel steeds duidelijker dat alleen met een in tijd, tijdsduur en plaats afwisselende inzet een optimaal resultaat kan worden bereikt. Met voor sommige soorten eventueel in combinatie met ondersteunend afschot. Ook is duidelijk dat voor de preventie of vermindering van de faunaschade geen generiek recept valt uit te schrijven maar vaak om maatwerk op bedrijfsniveau vraagt, en - vanwege het risico op gewenning - ook veel discipline en continuïteit in de uitvoering.

Het is dan ook niet verwonderlijk dat bij de landbouw, als belang met de grootste schade, betrokken Faunabeheereenheden en provincies behoefte is aan een dekkend en actueel inzicht in de effectiviteit van wildwerende middelen.

Het doet mij dan ook genoegen dat WENR er in is geslaagd om voor de belangrijkste schadeveroorzakende soorten uit al de beschikbare wetenschappelijke literatuur deze kennisreview op te stellen. Hier ligt een voor Nederland compleet actueel beeld van de wetenschappelijke inzichten op tafel. Het is nu de uitdaging deze inzichten te benutten voor de Faunabeheerplanning en te vertalen naar de praktijk. Een woord van dank gaat uit naar het Ministerie van Landbouw, Natuur en Voedselkwaliteit dat aan de basis van deze kennisreview heeft bijgedragen in het kader van het Beleidsondersteunend Onderzoek.

Maar er is meer!

Voor u ligt ook een methodiek voor de beoordeling van de opzet en rapportages van effectiviteitstudies en voorstellen voor nieuw onderzoek. Deze methodiek zie ik als een gouden standaard en maatlat om naar veldresultaten van onderzoek te kijken en te benutten voor het opzetten van nieuwe studies. De beoordelingsmethodiek voegt kwaliteit toe aan het onderzoeksmodel van BIJ12 en helpt deze in de beoordeling. Omdat wetenschap nooit de absolute waarheid in pacht heeft of zal hebben, zal er altijd sprake zijn van verschil in inzicht en ruimte zijn voor interpretatie. De maatstaven die in de beoordelingsmethodiek voor nieuw onderzoek worden gehanteerd, moeten dan ook altijd bespreekbaar zijn binnen de wetenschap en tussen wetenschap en de verantwoordelijke en betrokken maatschappelijke partners in de uitvoering van de faunaschadebestrijding. BIJ12 ziet de methodiek als een geobjectiveerde kwaliteitsmaatlat voor onderzoeken, een belangrijk middel om over het oppakken van nieuw onderzoek te beslissen. Een soort programma van eisen. Om nieuwe inzichten in het onderzoek en de beoordeling ervan een plek te geven is het verstandig het gebruik van de methodiek over enkele jaren te evalueren en zo als lerend protocol te hanteren!

Ton Heeren

Coördinator Kennis en Onderzoek BIJ12 


\section{Samenvatting}

\section{Aanleiding}

In 2016 is voor het Faunafonds een analyse gedaan naar de wetenschappelijke kwaliteit van onderzoeken voor wildverjaging (Buij et al., 2016). Daarin zijn diverse criteria onderscheiden en zijn de getraceerde onderzoeken op hun wetenschappelijke kwaliteit beoordeeld. Tevens is een overzicht gemaakt van de werkzaamheid en effectiviteit van de verschillende verjagingsmethoden.

Het Faunafonds heeft naast dit overzicht ook behoefte aan een meer uitgeschreven overzicht van het ecologische verhaal rond verjaging: waarom werken bepaalde middelen wel en andere niet? Hoe zit de ecologie van die soorten in elkaar? Waarop grijpen die middelen aan? In dit rapport is van de top 10 van schadelijkste soorten in Nederland overzicht opgesteld van de wetenschappelijke bevindingen rond verjagen en schadereductie. Tevens is een overzicht gemaakt van aanknopingspunten voor verder onderzoek om tot een verdere beheersing van de schade te komen, waarbij tevens de duurzaamheid van de staat van instandhouding is meegenomen.

Daarnaast heeft het Faunafonds ook behoefte aan een handreiking, een soort protocol, aan de hand waarvan men zich een oordeel kan vormen over de kwaliteit van onderzoek en de zinvolheid ervan. In de praktijk krijgt het Faunafonds continu vragen voor nieuw uit te voeren onderzoek. Het fonds heeft behoefte om aan de buitenwereld duidelijk te kunnen maken hoe die afweging in haar werk gaat en daarover transparant te zijn. Een leidraad is opgesteld om wetenschappelijk onderzoek rond verjaging/schadebestrijding te kunnen beoordelen. Deze leidraad kan tevens worden gebruikt om tot een standpunt te komen over de wenselijkheid van nieuw uit te voeren onderzoek. Deze leidraad kan ook bij wijze van checklist worden gebruikt door diegenen die een verzoek tot onderzoek aan BIJ12 voorleggen. Daarbij is duidelijk dat uiteindelijke standpuntbepaling over de zinvolheid en het benodigde niveau van wetenschappelijke kwaliteit van onderzoek een zaak van het fonds is, die niet door anderen kan worden overgenomen. De handreiking is dus uitdrukkelijk een hulpmiddel, waarvan het fonds zelf 'het stuur' zal moeten vasthouden. Met de handreiking kan ervaring worden opgedaan en deze zal zich in de praktijk moeten bewijzen. 


\section{$1 \quad$ Inleiding}

Voortbouwend op het overzicht over wetenschappelijk onderzoek naar wildverjaging dat voor het Faunafonds is opgesteld (Buij et al., 2016), heeft het Faunafonds behoefte aan een uitgeschreven overzicht van het ecologische verhaal rond verjaging van schadelijk wild: waarom werken bepaalde middelen wel en andere niet? Hoe zit de ecologie van die soorten ten aanzien van al of niet effectieve verjaging in elkaar? Waarop grijpen die middelen ecologisch gezien aan? Voor de top 10 van de schadelijkste soorten is in dit rapport een en ander uitgeschreven. Het gaat om de volgende soorten/soortengroepen:

- Mezen: koolmees en pimpelmees

- Ganzen: grauwe gans, kolgans, brandgans en rotgans

- Smient (in de winter)

- Das

- Edelhert

- Wild zwijn

- Knobbelzwaan

De belangrijkste te bespreken maatregelen zijn:

- Weren (door bijv. netten, stroomdraad of hekken)

- Verjagen

- Habitatbeheer (op schade gevoelige percelen habitatgeschiktheid verlagen, elders juist vergroten)

- Populatiebeheer (met niet-lethale middelen, zoals anticonceptie)

Dit overzicht wordt hieronder gepresenteerd (5.1).

Daarop aansluitend heeft het Faunafonds behoefte aan een handreiking. Het gaat om een soort protocol, waarin de resultaten van bovenstaande zodanig worden aangeboden, dat men zich aan de hand daarvan een oordeel kan vormen over de kwaliteit van onderzoek en de zinvolheid ervan. In de praktijk krijgt het Faunafonds namelijk continu vragen voor nieuw uit te voeren onderzoek. Het fonds heeft behoefte om aan de buitenwereld duidelijk te kunnen maken hoe die afweging in haar werk gaat. Het fonds wil daarin zo transparant mogelijk zijn. Dit protocol zou zowel bruikbaar moeten zijn voor het beoordelen van reeds uitgevoerd onderzoek als voor de standpuntbepaling of aan een onderzoekverzoek tegemoet moet worden gekomen. Dit zou een checklist kunnen zijn. Deze handreiking is hieronder uitgewerkt en kan als checklist ter hand worden genomen (5.2). 


\section{Doelstelling}

Het doel van dit rapport is tweeledig. In de eerste plaats biedt het een overzicht van de bestaande kennis ten aanzien van omgaan met en het beperken van landbouwschade veroorzaakt door de top 10 van schadelijkste diersoorten of soortgroepen in Nederland. Er is gekozen voor een benadering die inzichtelijk maakt waarom soorten op bepaalde maatregelen sterker reageren dan op andere. Met andere woorden: we laten het niet alleen bij een opsomming van de effectiviteit van verschillende middelen, maar proberen ook een interpretatie te geven waarom - vanuit een ecologische benadering en vanuit het gedrag van de soort - bepaalde maatregelen beter werken dan andere. Dit overzicht kan vervolgens dienen als hulpmiddel bij het gericht ontwikkelen en testen van nieuwe schade-reducerende methoden.

In de tweede plaats is een leidraad uitgeschreven om tot een beeld te komen of onderzoeken gericht op schadereductie adequaat zijn. Hieraan bestaat behoefte, omdat er in de wildschadepraktijk van een continue stroom aan onderzoeksvragen en -verzoeken sprake is, waarvoor het Faunafonds en andere betrokkenen een standpunt moeten ontwikkelen welk onderzoek zinvol is en welk niet. 


\section{Methode, uitvoering}

\section{Opstellen overzicht bestaande kennis}

Een aantal verschillende maatregelen wordt hier besproken:

- Weren van schadesoorten (door bijv. netten, stroomdraad of hekken)

- Verjagen van schadesoorten

- Habitatbeheer (bij gevoelige percelen habitatgeschiktheid verlagen, elders juist geschikter maken)

- Populatiebeheer (met niet-lethale middelen, zoals anticonceptie)

Afbakening: in dit rapport ligt de nadruk op niet-lethale maatregelen, al of niet in combinatie met ondersteunend afschot. De maatregelen worden besproken in relatie tot de volgende belangrijke schadesoorten of soortgroepen:

- Mezen: koolmees en pimpelmees

- Ganzen: grauwe gans, kolgans, brandgans en rotgans

- Smient (in de winter)

- Das

- Edelhert

- Wild zwijn

- Knobbelzwaan

De maatregelen die worden besproken, hebben betrekking op verschillende ruimtelijke schalen, van perceelschaal tot regionale schaal. Vaak worden maatregelen getest op perceelschaal, waarbij de effectiviteit in een behandeld perceel wordt vergeleken met een onbehandeld (of controle)perceel. Daarbij is het makkelijk voor te stellen dat wanneer de doelsoort zich verplaatst, ook de schade zich verplaatst van een behandeld perceel naar een naburig perceel. De maatregelen die betrekking hebben op weren en verjagen, worden meestal op lage ruimtelijke schalen genomen. In veel gevallen is dan niet onderzocht wat het netto-effect is van de verplaatsing van de schade. Andere studies richten zich echter op het evalueren van maatregelen op bedrijfsschaal - dan gaat het er dus om of de maatregel op grotere, en wellicht meer relevante ruimtelijke schaal effectief is. Maatregelen die betrekking hebben op habitatbeheer kunnen op kleine, perceelschaal worden genomen, of grotere bedrijfsschaal. Habitatbeheer kan er ook op gericht zijn om schade te voorkomen op de schaal van meerdere bedrijven, of zelfs regio's. In de praktijk is dat bijvoorbeeld het geval met ganzenopvanggebieden, waarbij er op regionale schaal wordt gestreefd naar een combinatie van habitatbeheer en verjaging met ondersteunend afschot om de ganzen te concentreren in opvanggebieden. Tot slot vindt populatiebeheer in alle gevallen plaats op grote ruimtelijke schaal, zoals in Europa vooral het geval is met de fly way-beheerprogramma's van soorten als kleine rietgans en in de toekomst mogelijk grauwe en brandgans. De effectiviteit van dergelijke programma's bij het verminderen van schade op perceel-, bedrijfs- of zelfs internationale schaal is (nog) niet bewezen. Ze blijven hier daarom grotendeels buiten beschouwing, ook omdat ze vooral betrekking hebben op de inzet van lethale middelen (d.w.z. afschot) langs hele fly-way met als doel te populatiegrootte op een bepaald niveau te houden of te krijgen (de 'optimal harvest'-beheermodellen van soorten als kleine rietgans), en niet op schadereductie door verjaging (eventueel in combinatie met ondersteunend afschot) of habitatbeheer. In dit rapport wordt de ruimtelijke schaal van de maatregel genoemd bij de evaluatie van de effectiviteit van de maatregel. Hierbij dient dus in ogenschouw genomen te worden dat als een maatregel effectief is op perceelschaal, dat niet automatisch geldt op bedrijfsschaal of regionale schaal.

\section{Literatuurstudie}

Voor de weergave van de stand van kennis omtrent de effectiviteit van maatregelen om schade door de schadesoorten te voorkomen, hebben we de literatuur op dit specifieke onderwerp onderzocht. In Google Scholar en de scopus-database is gezocht naar technische rapporten en peer-reviewed artikelen over schadereductie voor de 10 soorten(groepen) in relatie tot het in de inleiding geschetste doel. Hierbij hebben we zoektermen gebruikt die betrekking hebben op de soortgroepen en de schadereducerende maatregelen. De gebruikte zoektermen, zoals crop damage, crop loss, Sus scrofa, 
prevention, deterrent en badgers (en variaties hierop, gebruikmakend van andere soortgroepnamen en maatregelen) werden gesteld in het Engels, maar werden ook vertaald naar Nederlands en Duits. Daarnaast zijn 155 rapporten van BIJ12 die betrekking hebben op schade, schade-reducerende middelen en de evaluatie daarvan bij dit overzicht betrokken en waar relevant verwerkt. Daarnaast hebben we de referentielijsten in de gevonden literatuur gescreend op additionele bronnen. In totaal hebben we op deze manier 321 referenties gevonden, waarvan ongeveer 190 relevant werden bevonden voor de literatuurreview. Bij de selectie van buitenlandse wetenschappelijke literatuur is vooral gezocht naar studies die in detail en statistisch rigoureus een specifieke methode toetsen; andere rapportages die vooral beschrijvend van aard zijn en statistische toetsing (geheel) achterwege laten, zijn uitgesloten uit ons overzicht (zie voor methodiek Buij et al., 2016).

\section{Scoren van effectiviteit en kosten van maatregelen}

Op basis van de informatie in de literatuur geven we per verjaagmethode een schatting van de relatieve effectiviteit (dat wil zeggen de invloed op de aanwezigheid van de soort op een schadegevoelig perceel of de schadevermindering ten opzichte van andere methoden) en de uitvoeringskosten. Die schattingen zijn relatieve schattingen ten opzichte van andere methoden en niet absoluut, omdat de precieze kosten (materiaal- en arbeidskosten) van de inzet van bepaalde methoden vaak niet gegeven worden. Wel worden regelmatig termen als 'relatief duur' of 'goedkoop' aan een bepaalde methode verbonden. Belangrijk hiaat hierbij is dat niet altijd zowel de arbeids- als materiaalkosten zijn meegenomen in een beoordeling in rapporten en literatuur, waardoor vergelijkingen problematisch zijn. Mocht er twijfel bestaan over de relatieve kosten, dan is de inschatting gemaakt door de auteurs op basis van de beschikbare informatie en inzichten. In de tabellen onder de soortgroepen wordt aangegeven of de kosten of de effectiviteit relatief als erg laag (---) of hoog $(+++)$ worden ingeschat, of dat er variatie optreedt als gevolg van specifieke omstandigheden of voorwaarden voor een goede toepassing (zoals $0 /+$; met 0 een indicatie van gemiddelde kosten of efficiëntie en + wijzend op een afwijking naar hogere dan gemiddelde kosten of effectiviteit onder sommige omstandigheden of voorwaarden).

\section{Opstellen leidraad beoordeling onderzoek}

In overleg met de opdrachtgever is bepaald aan wat voor leidraad behoefte is. Aanvankelijk was het idee om een zogenaamde beslisboom op te stellen die men langs zou kunnen lopen om tot een beeld te komen. Een beslisboom veronderstelt een hiërarchie van aspecten: eerst het belangrijkste kenmerk. Voldoet het onderzoek daar niet aan, dan 'valt het af'. Voldoet het onderzoek daar wel aan, dan volgt het tweede aspect etc. Het idee was voorts om de beslisboom te focussen op wetenschappelijke kwaliteit van het onderzoek. Dit bleek niet goed werkbaar. Er zijn buiten de wetenschappelijke aspecten diverse kenmerken die bepalen of een onderzoek zinvol is. Deze aspecten zijn besproken en op een rij gezet in een overleg waarin enkele vertegenwoordigers uit het veld aanwezig waren. Aan de hand daarvan is een verhaal uitgeschreven waarin deze aspecten zijn meegenomen. Begonnen is met een casus uit de praktijk, aangereikt vanuit het Faunafonds. Deze is specifiek (gericht op wel/niet onderzoek doen aan legselbehandeling) en probeert de lezer mee te nemen hoe je tot een beeld kan komen of onderzoek wenselijk is. Daarna is een meer generiek verhaal uitgeschreven. Deze handreiking pretendeert meer algemeen bruikbaar te zijn. Wat daarin duidelijk wordt, is dat het opbouwen van een beeld of onderzoek zinvol is door specifieke omstandigheden wordt bepaald. Het gewicht dat aan de verschillende aspecten wordt toegekend, verschilt van geval tot geval. Dit heeft uiteindelijk geleid tot een wegingstabel, die per keer door de 'beoordelingscommissie' kan worden aangepast. Voordeel hiervan is dat expliciet wordt gemaakt welk gewicht aan de verschillende aspecten wordt gegeven en tot welke score dat leidt. Dit kan de transparantie van de standpuntbepaling ten goede komen. Met dit geheel zal ervaring moeten worden opgebouwd. 


\subsection{Overzicht verjagingsonderzoek van de 10 belangrijkste schadesoorten}

\section{Box 1. De 'ecologie van verjagen'}

De hier behandelde 'schadesoorten' zijn in ons land alle potentiële prooidieren voor carnivoren en/of roofvogels, met uitzondering van de das. Daarnaast is de mens als jager een belangrijke predator voor alle soorten. Deze predatoren kunnen niet alleen de individuele fitness- en populatieprocessen van de prooidieren beïnvloeden door dodelijke effecten (als gevolg van directe consumptie), maar ook door niet-dodelijke effecten, waarbij gedragsverandering van de prooidieren optreedt door hun inschatting van de predatierisico's (Houston et al., 1993; McPeek, 2004; Cresswell, 2008). In het laatste geval gaat het bijvoorbeeld om schadesoorten die gebieden met een hoog predatierisico vermijden. Studies hebben inmiddels aangetoond dat de niet-dodelijke effecten die predatoren uitoefenen op hun prooien groter kunnen zijn dan dodelijke effecten (gebieden waar gevaar dreigt worden gemeden). Deze effecten bepalen onder andere het gedrag, de conditie, de dichtheid en de verspreiding van allerlei diergroepen, inclusief zoogdieren en vogels. Tijdens het foerageren maken prooidieren constant afwegingen tussen het door hen gevoelde predatierisico en voedsel- of energie-opname (Lima et al., 1985; Houston et al., 1993); het gaat daarbij steeds om afwegingen tussen het maximaliseren van overleving in aanwezigheid van predators en het verwerven van voedsel voor langdurige overleving of voortplanting.

Deze afweging tussen predatierisico en voedselgeschiktheid is de kern van de strategie voor het voorkomen van schade: als de gefingeerde of daadwerkelijke predatiedruk op een overtuigende manier kan worden gestimuleerd, zullen schadesoorten sneller geneigd zijn uit te wijken naar alternatieve voedselgebieden, zeker als die laatste relatief weinig schadegevoelig zijn ten opzichte van kostbare, schadegevoelige gewassen. Overigens kunnen de afwegingen tussen predatiedruk en

voedselgeschiktheid variëren gedurende het jaar (Yasué et al., 2003). Als de mogelijkheden voor energieopname bijvoorbeeld groot zijn, zal een vogel een groter predatierisico accepteren dan wanneer die mogelijkheden klein zijn (Cresswell, 1994). Als de kans op predatie toeneemt en het voedselaanbod afneemt, zal het individu of de groep uitwijken naar een locatie met lagere predatiekans (Cresswell, 1994). Door rekening te houden met die afweging kunnen we beter voorspellen hoe veranderingen in (schijnbare) predatiedruk - zoals door verjaagmiddelen - en voedselbeschikbaarheid het gedrag van een schadesoort zullen beïnvloeden en hoe dieren zullen reageren op toenemende gevoelde predatierisico. De afwegingsbenadering is erg nuttig om te voorspellen hoe predatierisico's het gebruik van kwetsbare gewassen beïnvloeden, doordat roofdieren vermeden worden.

Het risico op predatie wordt als aanzienlijk ingeschat als aanwezigheid van die predator kan worden vastgesteld of zelfs maar gesuggereerd. Dit kan bijvoorbeeld door vogelverschrikkers, mensen of modellen (d.w.z. levensecht uitziende beelden) van roofvogels of uilen, maar ook door veranderingen in het landschap die de kwetsbaarheid voor de soorten voor predatie vergroten. Een goed voorbeeld hiervan zijn singels of heggen door het landschap, die door ganzen worden geassocieerd met de aanwezigheid van belangrijke predatoren als vossen (Fox et al., 2017). In veel gevallen is de omgeving zelfs belangrijker dan de zichtbaarheid van de predator; veel prooidieren leiden predatiekans af uit de samenstelling van het landschap (Whittingham en Evans, 2004). Met andere woorden: de predatiekans, of schijnbare predatiekans, kan niet alleen worden vergroot door het ten tonele laten komen van overtuigende modellen van roofdieren, of roofdieren, maar ook door het veranderen van het landschap door habitatbeheer.

Deze review richt zich op al deze aspecten van effectieve schadevermindering: (a) het overtuigend fingeren van de aanwezigheid van predator en door predatormodellen, (b) het verhogen van daadwerkelijk predatierisico door de introductie of het faciliteren van predatoren, (c) het beheren van habitat om het gevoelde predatierisico op schadegevoelige percelen toe te laten nemen en (d) de relatieve geschiktheid van alternatieve voedselgebieden verbeteren ten opzichte van de schadegevoelige percelen. Al die maatregelen zijn er dus op gericht om de balans tussen risico (kans om gedood te worden) en opbrengst (nutriëntrijk voedsel) door te laten slaan naar risico, zodat schadesoorten uitwijken naar elders en de schade op de relevante ruimtelijke schaal afneemt. 


\section{Mezen: koolmees en pimpelmees}

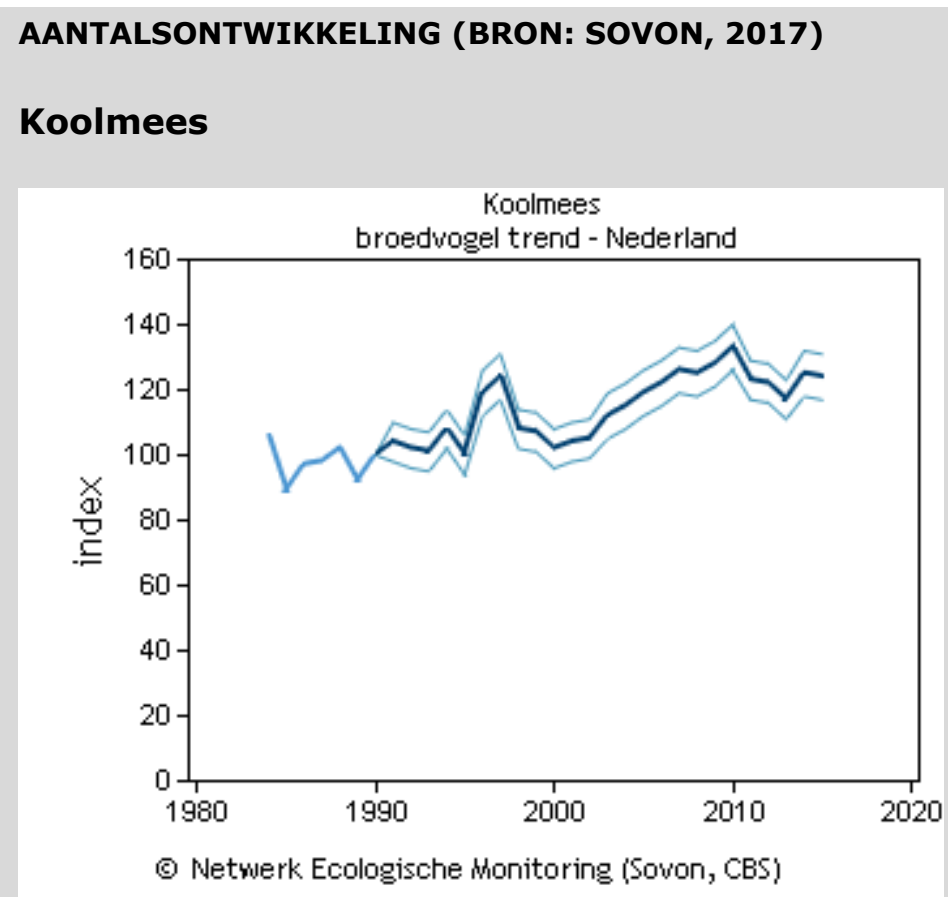

De broedvogeltrend is gebaseerd op het Meetnet Broedvogels (BMP). Weergegeven is de jaarlijkse index van de broedpopulatie t.o.v. 1990 en de standaardfout.

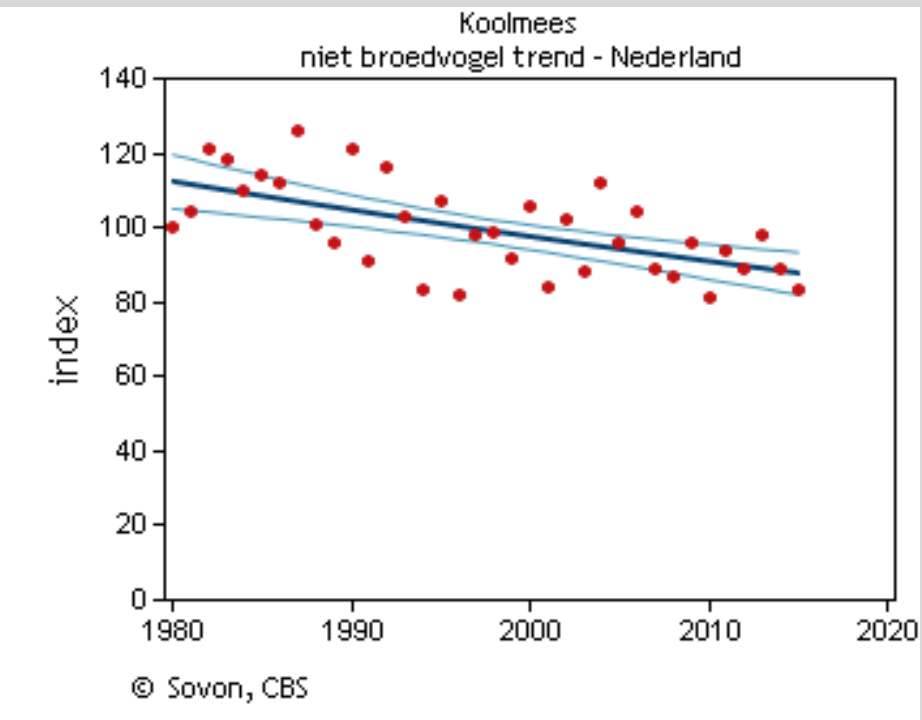

De niet-broedvogel trend is gebaseerd op het Punt Transect Tellingen project (PTT). Weergegeven is de jaarlijkse index van de winterpopulatie in december (rode punten), de trendlijn (donkergekleurde lijn) en het 95\%-betrouwbaarheidsinterval.

\section{Buiten broedtijd}

De Nederlandse koolmezen blijven vrijwel allemaal op korte afstand van de geboorteplek. OostEuropese vogels trekken in het najaar door, soms in forse aantallen. Zulke trek speelt zich af tussen half september en half november, met de piek doorgaans midden oktober. Een goede oogst van beukennoten en bijvoedering in dorpen en steden is vooral voor onvolwassen vogels gunstig. Streng winterweer kan tot omvangrijke sterfte onder de overwinteraars leiden als er weinig voedsel beschikbaar is. De voorjaarstrek voltrekt zich meestal bijna onmerkbaar tussen half februari en half april. 


\section{Broedtijd}

In heel Nederland zijn koolmezen te vinden, enkele boomloze gebieden daargelaten. De soort heeft een voorkeur voor oud loofbos, maar kan door het ophangen van nestkasten ook in andere bostypen of in stedelijk gebied hoge dichtheden bereiken. Afgezien van de vlotte kolonisatie van geschikte nieuwe gebieden (bijvoorbeeld zuidelijk Flevoland, drooggelegd rond 1970) is de verspreiding al vele decennia ongewijzigd. De landelijke aantallen namen in dezelfde periode licht toe, met inzinkingen na winters met strenge vorst en veel sneeuw. De toename zal (deels) samenhangen met het ouder en geschikter worden van veel bossen en het aanleggen van groenvoorzieningen in verstedelijkend, voorheen open landschap. In naaldbossen op arme zandgronden zijn de broedresultaten matig door kalkgebrek en wordt enige afname verwacht.

\section{Pimpelmees}

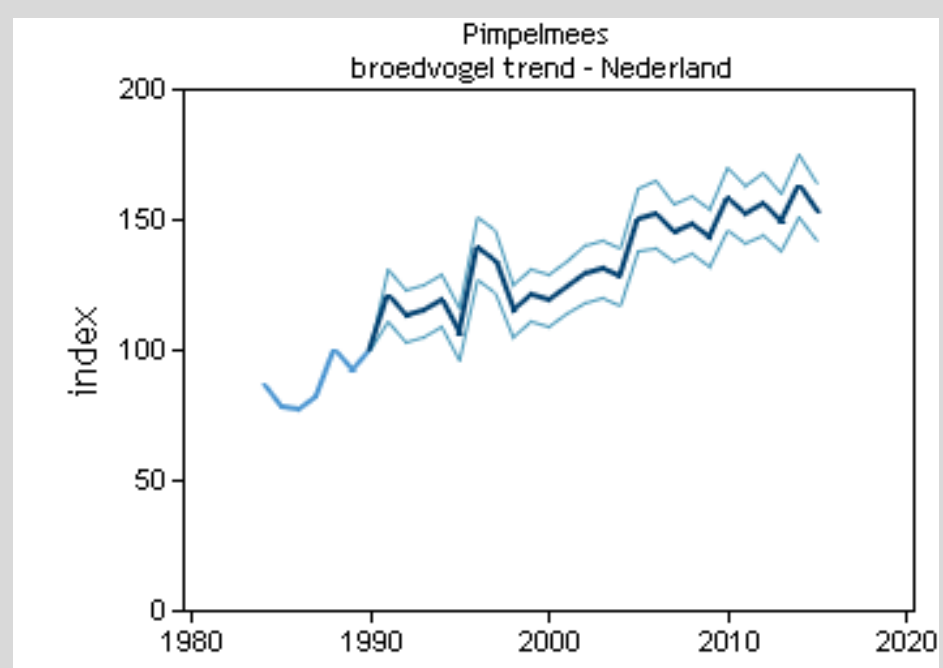

(9) Netwerk Ecologische Monitoring (Sovon, CBS)

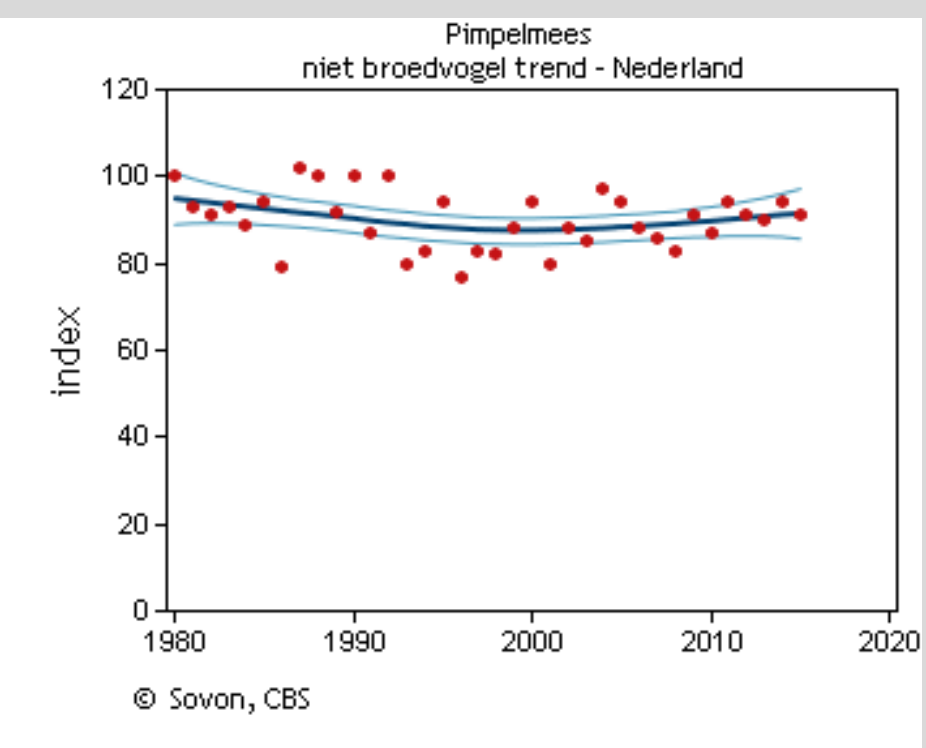

\section{Broedtijd}

Pimpelmezen ontbreken vrijwel nergens in Nederland waar bomen staan. Ze zijn het talrijkst in oud loofbos op de hoge gronden, maar het ophangen van nestkasten kan de dichtheden ook in andere biotopen verhogen. Nieuw beschikbaar gebied wordt vlot gekoloniseerd, zoals op grote schaal bleek uit het in gebruik nemen van zuidelijk Flevoland, drooggelegd rond 1970 en nog geen kwart eeuw later volledig bezet. De landelijke aantallen nemen geleidelijk toe. Het ouder worden van bossen (meer nestgelegenheid) speelt hierbij een rol, net als verstedelijking (met in het kielzog groenvoorziening) in voorheen open gebied in West- en Noord-Nederland. 


\section{Buiten broedtijd}

In de nazomer vormen lokale broedvogels soms groepen die tot in de winter intact blijven. In herfst en winter vullen Oost- en misschien Noord-Europese pimpelmezen de Nederlandse populatie aan die zich als standvogel gedraagt. De doortrek vindt tussen half september en half november plaats, met de piek meestal half oktober. De trek is in sommige najaren aanzienlijk, met op stuwingspunten honderden trekkers per dag, maar is meestal nogal onbeduidend. De overwinteraars gedijen bij zacht weer en een goede zaadoogst van berken, haagbeuken, Spaanse aak maar ook riet. Van de voorjaarstrek tussen half februari en half april is doorgaans weinig te merken.

\section{Betekenis als schadesoort}

Mezen, met name de kool- en pimpelmees, zorgen voor veel schade, voornamelijk in fruitboomgaarden. Zij zijn verantwoordelijk voor $67 \%$ van de door vogels aangerichte schade, de rest is niet naar soorten te herleiden (Dulos en Visser, 2006). De zoetere fruitrassen, zoals perenrassen Conference en Triomphe de Vienne, ondervinden de meeste schade, terwijl stoofperen en zuurdere appelsoorten veel minder in trek zijn (Dulos en Visser, 2006).

De afgelopen jaren is er sprake van een vermindering van de uitgekeerde schade die werd toegeschreven aan mezen (Fig. 1), naar het niveau van 2004. Het piekjaar was 2012, toen er $€ 2,3 \mathrm{mln}$ werd uitgekeerd aan mezenschade, wat deels te verklaren is door hoge oogstprijzen. In de periode 2000-2016 waren kool- en pimpelmezen met $€$ 8,8 mln toegekeerde schade verantwoordelijk voor ca. $7 \%$ van de totale toegekeerde schade aan de top 10 -schadesoorten.

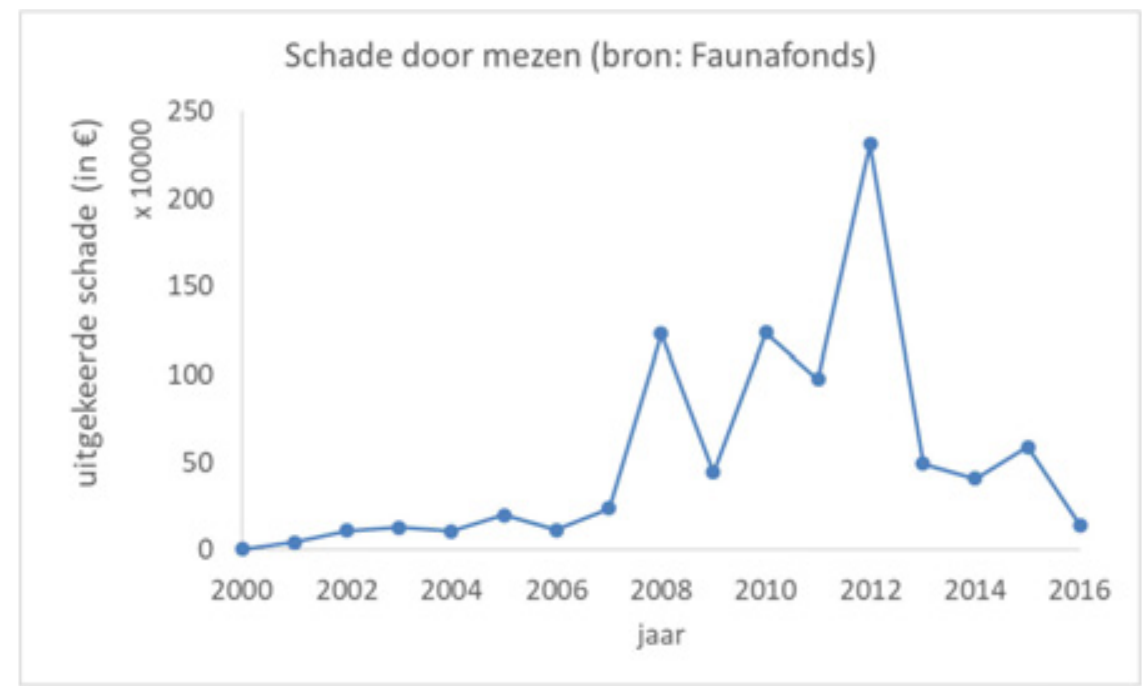

Figuur 1 Bedrag (in €) uitgekeerd voor schade toegekend aan mezen gedurende 2000-2016.

\section{Betekenis als nuttige soort}

Samen met pimpelmezen kunnen koolmezen ook behulpzaam zijn voor eigenaren van fruitbomen en grote fruitgewassen, omdat ze de bladeren van deze gewassen ontdoen van onder andere rupsen (Mols en Visser, 2002, 2007; Mols et al., 2005). Op die manier verzorgen ze een biologische bestrijding van rupsen. Bekend is dat mezen de insectendichtheid (inclusief rupsen) kunnen verlagen en daarmee de bladschade kunnen verminderen (Murakami en Nakano, 2000; Sanz, 2001). Deze studies lieten zien dat het verhogen van de dichtheid van koolmezen door het ophangen van nestkasten een positief effect had door het omlaagbrengen van de bladschade - en dat bij een hogere mezendichtheid de bladschade verder afnam. Studies in Nederlandse boomgaarden lieten vervolgens zien dat gemiddeld $6 \%$ van de rupsen in een boomgaard van 1 ha kan worden verwijderd door 1 paar koolmezen, aannemend dat ongeveer de helft van de foerageervluchten in de boomgaard plaatsvindt (Mols et al., 2005). Bij een dichtheid van 2-4 broedpaar per ha kunnen de rupsenaantallen met $23 \%$ worden teruggebracht. Dit kan oplopen tot $49 \%$ als de mezen exclusief in de fruitboomgaard foerageren (Mols et al., 2005). Appeltelers kunnen hieraan bijdragen door nestkasten op te hangen. Het reduceren van schade door 
koolmezen door het ophangen van nestkasten is zeer kosteneffectief (kosten zijn ca. $€ 20$ per ha per jaar), waardoor de schade met de helft beperkt kan worden (Mols en Visser, 2007). Op basis van deze onderzoeken kan geconcludeerd worden dat koolmezen en pimpelmezen in staat zijn de aantallen van rupsen en andere blad etende insecten te verlagen en daarmee de vraatschade te verminderen. Op die manier kunnen mezen een grote bijdrage leveren aan het beperken van schade in de fruitteelt, hoewel op dit moment nog onduidelijk is wat het netto-effect kan zijn.

\section{$1.1 \quad$ Belangrijkste werings- of verjagingsmiddelen}

De hieronder te bespreken methoden zijn veelal getest op andere soorten zangvogels dan mezen; onze inschatting is evenwel dat deze bevindingen ook van toepassing zijn op kool- en pimpelmezen.

\subsubsection{Fysieke barrières}

Mezen kunnen met fysieke barrières worden tegengehouden. Dat kan bijvoorbeeld gaan om hagel- of vogelnetten. Met een combinatie van vogel- en hagelnetten kan een perceel perenbomen volledig worden afgesloten voor mezen (Van Bommel, 2016). Netten om boomgaarden in zijn geheel tegen mezen te beschermen, zijn zeer effectief, maar relatief duur (ca. $€ 2.740$ per hectare (inclusief arbeidskosten); Helmus, 2013). De kans bestaat dat mezen bij toepassing van enkel hagelnetten alsnog schade toebrengen. Een combinatie met vogelnetten aan de zijkanten ter afsluiting zal vogelschade waarschijnlijk volledig voorkomen, terwijl alleen hagelnetten onvoldoende bescherming bieden. Bij beperkte vogelaantallen zijn netten niet het geëigende middel, omdat de kosten niet opwegen tegen de schade (Buij et al., 2016). Vooral als de kosten voor het verwijderen en opzetten van netten hoog zijn, zullen netten in de praktijk alleen bij vruchten met een hoge prijs gebruikt worden (Fuller-Perrine en Tobin, 1993). De effectiviteit van netten zou kunnen worden vergroot door eerst de mezen en andere zangvogels te verjagen met andere middelen, omdat deze vogels weinig geneigd zijn naar gaten te zoeken (Marsh et al., 1991, 1992).

\subsubsection{Visuele verjaagmethoden}

Vogelverschrikkers en roofvogelmodellen

Vogelverschrikkers hebben een lange geschiedenis (Frings en Frings, 1967; Achiron, 1968), maar de traditionele modellen (poppen e.d. die mensen nabootsen) bieden slechts zeer kort bescherming of zijn zelfs contra-effectief (Marsh et al., 1991, 1992). Sommige vogels gebruiken ze als zitplekken (DeHaven, 1971) of associëren ze met gunstig voedselgebied (Inglis, 1980). Naast vogelverschrikkers zijn ook ballonnen met een predatorprint gebruikt om zangvogels te verjagen. McLennan et al. (1995) vonden echter dat een ballon met een reflectief oog maar beperkt werkzaam was bij mussen (tot $40 \mathrm{~m}$ en slechts tot een periode van 9 dagen). Datzelfde geldt wellicht ook voor mezen, hoewel dat niet onderzocht is.

Het overtuigend imiteren van een relevante predator kan zorgen voor afschrikking van zangvogels, inclusief mezen. Daarom is veel aandacht besteed aan de ontwikkeling van waarheidsgetrouwe roofvogelmodellen (Conover, 1979, 1985; Marsh et al., 1991, 1992; McLennan et al., 1995).

Echter, in de meeste situaties blijkt ook een modelroofvogel niet voldoende te lijken op een daadwerkelijke predator om een sterke en langdurende verjagende werking te hebben (Conover, 1979; Inglis, 1980; Marsh et al., 1992). Zelfs de beste roofvogelmodellen bieden alleen kortdurende bescherming, omdat vogels kennelijk snel doorhebben dat ze geen echte bedreiging vormen en er gewenning optreedt (Marsh et al., 1991, 1992). Voor sommige modellen lijkt er wel een sterk effect, echter van korte duur (uren) te zijn. Rensel en Wilder (2012) bijvoorbeeld testten de reactie van zangvogels op een levensechte, plastic uil (Amerikaanse oehoe Bubo virginianus) in verhouding tot de reactie op een kartonnen doos, met dezelfde grootte en kleur van de uil. De plastic uil schrok de vogels af van voedertafels, terwijl de controledoos geen reactie gaf. Met doos waren de aantallen vogels niet significant anders dan zonder doos. De vogels reageerden dus niet op de aanwezigheid van een vreemd object (de doos), maar ze leken de plastic uil te herkennen als een potentieel gevaar en reduceerden daarom hun bezoeken aan voedertafels. Wel is deze studie uitgevoerd met korte observatieperioden (intervallen van 15 minuten), waardoor niets geconcludeerd kon worden over de duur van het verjagingseffect. 
Die langetermijneffectiviteit lijkt groter als er sprake is van (onregelmatige) beweging. Conover (1979) bijvoorbeeld evalueerde eerder het effect van drie roofvogelmodellen (opgezette havik Acccipiter gentilis en opgezette Amerikaanse sperwer Accipiter striatus, en een vlieger met de afbeelding van een vliegende arend) op het aantal zangvogels (overigens geen mezen) binnen plots met bosbessen in Noord-Amerika. Het effect van de modellen werd op korte termijn (uren) en op langere termijn (tot 7 dagen na plaatsing van de modellen) onderzocht door vergelijking van aantallen vogels tussen plots met roofvogelmodellen met controleplots. Bij opgezette roofvogels (havik)was het aantal foeragerende vogels significant lager, maar trad na 5 tot 8 uur blootstelling gewenning op, hoewel dit verschilde per soort (zang)vogel. Bij een roofvogelvlieger (bewegend model) was het effect groter (Conover, 1979). De gewenning aan de opgezette havik kwam tot uitdrukking door de grotere aantallen vogels na verloop van tijd. De auteur suggereert dat een zittende, statische roofvogel mogelijk zelfs vogels aantrekt, omdat zittende predators vaak door vogelgroepen worden belaagd. Als foeragerende vogels vervolgens geen negatief effect van de predator ondervinden (zoals een aanval), kan snel gewenning optreden. Bij de veel dynamischer roofvogel-vlieger is dit niet het geval (Conover, 1979). Op de langere termijn (7 dagen) was het aantal zangvogels op de plots met vlieger gemiddeld $40 \%$ lager dan het aantal vogels op de controleplots, hoewel het effect op schade onbekend bleef. Op dagen met wind is de vlieger effectiever dan op dagen zonder wind, wat bevestigt dat beweging, liefst onregelmatig, van groot belang is voor de verjagende werking.

Vliegers die de vorm of het silhouet hebben van een roofvogel lijken dus een relatief langdurig effect te kunnen bewerkstelligen; in ieder geval gedurende een termijn van dagen of weken, vooral bij wind (Conover, 1979; Hothem en DeHaven, 1982). Roofvogelvliegers aan helium-gevulde ballonnen verminderen de schade door zangvogels aanzienlijk: in bosbessen met 35-40\%; in wijngaarden met $32-88 \%$ (gem 48\%) en in graanvelden (met 83\%), zo laten Amerikaanse onderzoeken zien (Conover, 1979, 1982; Hothem en DeHaven, 1982; Conover, 1984). De effectiviteit van dergelijke vliegers kan worden versterkt door gebruik van de afbeelding van een soort die voorkomt in het lokale gebied (Marsh et al., 1991).

\section{Reflectoren}

Reflectoren zijn bijvoorbeeld compact discs, guirlandes en tapes die rond fruitboomgaarden worden gehangen voor visuele afschrikking. De door wind bewogen reflectoren zouden zangvogels als mezen moeten afschrikken, zodat ze minder snel geneigd zijn te foerageren. Grote beperking van het gebruik van reflectoren is, net als bij andere draaiende of flapperende afschrikmiddelen, snelle gewenning als de windsnelheid te laag is voor beweging (Marsh et al., 1991). Wind doet de effectiviteit van visuele schrikapparaten toenemen (Tobin et al., 1988; Marsh et al., 1991). Een goed voorbeeld hiervan zijn compact discs hangend aan een snoer die in de wind lichtflitsen veroorzaken. Bij harde wind kunnen dergelijk middelen ineffectief worden (zelfs kapotwaaien). Dergelijke middelen kunnen overigens verschillende effecten hebben op verschillende soorten zangvogels (Dolbeer et al., 1986; Tobin et al., 1988). Voor mezen is de effectiviteit nog onvoldoende onderzocht. Wel lieten experimenten met de FireFly Bird Diverter, een bakenkaart met reflecterende stickers die daglicht en uv-licht reflecteren, hoopgevende resultaten zien (Van den Bremer et al., 2009; Van den Bremer en Hallmann, 2011). Deze studies op fruitkwekerijen met Conferenceperen toonde dat de FireFly een redelijk tot zeer sterk verminderend effect heeft op de hoeveelheid schade door zangvogels, in belangrijke mate mezen, maar de effectiviteit van het middel op langere termijn (van enkele maanden, en dus gewenning) werd niet onderzocht. In een vervolgstudie werd vastgesteld dat plots in percelen met Firefly's gemiddeld 31 procent minder schade hadden dan controleplots en dat de schade toenam met de afstand tot de Firefly (tot ca. 60 meter; Van den Bremer en Hallmann, 2011).

\subsubsection{Akoestische verjaagmethoden}

Akoestische (geluid-producerende) verjaagmiddelen zijn apparaten die harde, verschrikkende geluiden produceren om zangvogels te weren uit boomgaarden. De meeste apparaten produceren hoge, harde geluiden die overigens vaak buiten de menselijke gehoorgrens vallen om irritatie te voorkomen. Akoestische verjaagmiddelen spelen in op angst voor ongewone, plotselinge, onverwachte, potentieel gevaarlijke gebeurtenissen (schrikstimulus).

Over het algemeen kan gesteld worden dat de effectiviteit van akoestische apparaten hoog is wanneer sprake is van de volgende elementen (Bomford en O'Brien, 1990; Bishop et al., 2003): 
1. Willekeurige intervallen van het geluid;

2. Verschillende typen geluiden;

3. Geluiden worden voldoende lang gespeeld om een vluchtreactie te bewerkstelligen;

4. De bron van het geluid verandert regelmatig van locatie;

5. Het geluid wordt aangevuld door andere afschrikmiddelen, vooral daadwerkelijk gevaar (zoals geweerschoten).

Bio-akoestische verjaagmiddelen produceren specifieke geluiden die worden gebruikt in inter- en intraspecifieke communicatie, zoals alarmroepen of elektronische nabootsingen van dergelijke roepen, waar vogels van schrikken. De alarmroepen worden opgenomen, soms gedigitaliseerd en gemodificeerd, versterkt en vervolgens uitgezonden via luidsprekers (Aubin, 1990; Marsh et al., 1991). Alarmroepen werken, omdat ze de suggestie wekken dat er een predator in de buurt is, waardoor een vluchtreactie wordt geïnitieerd. Dat kan in het geval van koolmees ook de alarmroep van een andere soort zijn, zoals een pimpelmees of een andere vogelsoort. Met één alarmroep kunnen dus meerdere soorten worden verjaagd (Marsh et al., 1991). De eerste reactie op alarmroepen is vlucht, waarna de vogel de bron van de verstoring onderzoekt. Hierna kan eventuele gewenning ontstaan, omdat de verstoring niet gekoppeld kan worden aan daadwerkelijk gevaar (Bomford en O'Brien, 1990). De (bio)akoestische verjaagmiddelen zijn de meest toegepaste middelen bij de bestrijding van schade door zangvogels zoals de koolmees. Het verjagen van zangvogels met akoestische apparaten is in vergelijking met andere middelen relatief effectief, diervriendelijk, goedkoop en eenvoudig toepasbaar (Bomford en O'Brien, 1990).

Gewenning aan geluiden kan de effectiviteit van akoestische verjaagmiddelen echter sterk beperken, zeker op termijnen van weken of maanden. De geluidsstimulus kan zelfs een aantrekkende werking hebben, als de vogels leren de stimulus te associëren met voedsel (Conover en Perito, 1981). Het kan ook zo zijn dat vogels wegvliegen na de stimulus om daarna weer terug te keren en een andere tros druiven, peer of appel te beschadigen (Bomford, 1992). Zo neemt bij inefficiënte akoestische verjaging de schade regelmatig toe in plaats van af (Bomford, 1992).

De effectiviteit wordt waarschijnlijk in hoge mate bepaald door de kwaliteit van de geluidsopname en hoe vaak die herhaald wordt, maar degelijk onderzoek om dit te onderbouwen, ontbreekt nog. De meeste akoestische apparaten zijn ingesteld om automatisch af te gaan, vaak op willekeurige intervallen om de gewenning te minimaliseren. Net als bij visuele mechanismen wennen vogels als de geluiden afkomstig zijn van dezelfde puntbron of geen fysieke bedreiging vormen (Marsh et al., 1991). Onderzoek heeft aangetoond dat harde geluiden van een variabele frequentie beter werken dan zachte, continue tonen (Marsh et al., 1991). Vogels wennen bovendien snel aan een alarmroep als precies dezelfde roep vaak herhaald wordt in dezelfde sequentie (Summers, 1985; Aubin, 1990; Yokoyama en Nakamura, 1993; Harris en Davis, 1998). Een schriksysteem dat alleen werkt wanneer de vogels het apparaat zelf laten afgaan, is resistenter tegen dergelijke gewenning dan andere systemen (inclusief akoestische systemen die willekeurig geluiden voortbrengen; Stevens et al., 2000). Belangrijk blijkt verder dat de roep lokaal is opgenomen, omdat vogels sterker reageren op lokale dialecten (Marsh et al., 1991).

Naast alarmroepen is gesuggereerd dat de roep van een potentiële predator (voor koolmees bijvoorbeeld sperwer) een eventuele vluchtrespons zou kunnen uitlokken (Marsh et al., 1991). De gedachte hierachter is dat de aanwezigheid van de predator, via zijn roep, een vluchtreactie opwekt die de bezoekfrequentie aan boomgaarden omlaagbrengt. Hierdoor zou schade door die soorten kunnen afnemen. De effectiviteit hiervan is echter niet bewezen. Het ligt echter niet voor de hand dat de schrikreactie even sterk is als voor de alarmroep van soortgenoten of andere zangvogels, vooral omdat sperwers en andere roofvogels niet vocaliseren tijdens de jacht.

Bio-akoestische geluiden zijn niet altijd effectiever dan andere geluiden. Voor bijvoorbeeld huismussen waren geluiden van papieren vlaggen effectiever dan alarmroepen van soortgenoten (Yokoyama en Nakamura, 1993). In Nederland is in perenboomgaarden het zogenaamde krekelsysteem getest. Het krekelsysteem bestaat uit cilindrische metalen buizen, die een scherp ratelend geluid maken doordat er met hoge snelheid schakels tegen de binnenzijde van de buizen geslagen worden (Van den Bosch et al. 2014). Dit systeem beperkte de schade tot op een afstand van ca. $60 \mathrm{~m}$ en was werkzaam over een 
periode van 5 weken. Nabij de krekels en tot in ieder geval een afstand van $60 \mathrm{~m}$, trad in de proef een schadereductie op van $\pm 5 \%$ schade (bij een afstand van $300 \mathrm{~m}$ ) naar $<1 \%$ (bij een afstand van 0 en $60 \mathrm{~m})$.

\subsubsection{Combinatie van visuele en akoestische verjaagmethoden}

In de praktijk worden in veel gevallen diverse methoden in combinatie gebruikt, en dan vooral visuele met akoestische methoden. In het algemeen worden hiermee betere resultaten gehaald dan met enkelvoudige middelen (Bishop et al., 2003). In de meeste gevallen zijn visuele afweermiddelen alleen effectief in combinatie met andere verjaagtechnieken zoals akoestische verjaging, mogelijk omdat dit het beeld van een realistische predator versterkt (Bishop et al., 2003). Als een vogel bijvoorbeeld een alarmroep hoort, wordt het afschrikeffect groter als er daadwerkelijk een roofvogel te zien, zoals in de vorm van een vlieger (Marsh et al., 1991). Zoals al aangegeven: hoe levensechter het predatormodel (bijvoorbeeld met een worstelende prooi), hoe langzamer de gewenning optreedt (Conover en Perito, 1981; Conover, 1985). Als het geluid van een predator wordt toegevoegd, zal gewenning nog trager optreden en kan het effect weken of maanden aanhouden. Hetzelfde is van toepassing bij een (dynamische) vogelverschrikker, die een groter effect heeft in combinatie met een knallend geluid (Watkins et al., 2000).

Er zijn voor mezen geen onderzoeken gedaan naar de efficiëntie van levensechte predatormodellen, waarbij visuele en akoestische methoden werden gecombineerd. Voor andere zangvogelsoorten zijn dergelijke methoden wel getest, zoals voor spreeuwen. Conover en Perito (1981) bijvoorbeeld evalueerden de reactie van spreeuwen op predatormodellen met een dode of levende prooi. Het model was een uil, wel of niet samen met een alarmroep, of met een gevangen spreeuw. In aanwezigheid van de modeluil veranderden spreeuwen de foerageerlocatie en werd op grotere afstand gefoerageerd dan zonder modeluil. Wanneer alarmroepen werden afgespeeld verlieten de spreeuwen het gebied. Het sterkste effect had een modeluil met een levende vastgebonden spreeuw, waarbij een levende spreeuw een groter effect had dan een dode. Ook nu weer geldt: hoe levensechter de predator, hoe effectiever de verjaagmethode.

\subsubsection{Aantrekken van predatoren}

Hierboven zijn predatoren in geïmiteerde vorm al enkele malen als verjaagmiddel aan de orde geweest. In plaats van visuele of auditieve imitaties kunnen echte predatoren ook zelf als verjagers van zangvogels worden ingezet. Dat wordt in de praktijk vooral gedaan door het aanbrengen van zitplaatsen en nestkasten voor roofvogels (Askham, 1990; Kross et al., 2012,), overigens ook om schade door muizen te voorkomen (Kay et al., 1994; Meyrom et al., 2009; Paz et al., 2013; Labuschagne et al., 2016). Onderzoek in Nieuw-Zeeland liet zien dat de introductie van endemische Nieuw-Zeelandse valken in wijngaarden leidde tot een significante afname van zangvogels en een 95\%-afname in het aantal verwijderde druiven ten opzichte van wijngaarden zonder valken (Kross et al., 2012).

Als verjagers van kool- en andere mezen uit boomgaarden in ons land kan vooral aan vogeljagers van halfopen landschappen worden gedacht, zoals sperwer, havik of boomvalk (Bijlsma, 1993), maar die zijn niet of nauwelijks aan te trekken door het plaatsen van zitplaatsen of artificiële nestplekken rond boomgaarden. Torenvalken en buizerds zullen daarentegen aangeboden zitplaatsen wel gebruiken, zeker als die beperkt voorhanden zijn en er rond de boomgaard muisrijke plekken aanwezig zijn (Kay et al., 1994). Er zijn tot op heden geen onderzoeken die de effectiviteit van bijvoorbeeld torenvalken in boomgaarden op schadevermindering aantonen. Toch wordt het plaatsen van nestkasten voor torenvalken in boomgaarden regelmatig aangehaald als een goed middel om schade door zangvogels te verminderen (bijv. Dulos en Visser, 2006). Het gaat dan om de verschrikkende werking van oudervogels die aan- en afvliegen naar een nestkast tijdens het broedseizoen, dus niet zozeer het predatie-effect (Paz et al., 2013). In Nederland en elders in Europa is de effectiviteit voor schadereductie door zangvogels (nog) niet bewezen, maar voor het voorkomen van knaagdierschade zijn er veelbelovende resultaten (Hafidzi en Mohd, 2003; Paz et al., 2013; Labuschagne et al., 2016). Deze ervaringen wijzen op de noodzaak om degelijke studies uit te voeren om de efficiëntie van roofvogels als natuurlijke afschrikkers van zangvogels als mezen te evalueren. Dit is vooral van belang, omdat gebleken is dat consumenten bereid zijn meer te betalen voor fruit dat op 'natuurlijke' manier is beschermd tegen schade (Herrnstadt et al., 2016). 


\subsubsection{Habitatbeheer}

Met habitatbeheer wordt het leefgebied van - in dit geval mezen - zodanig gemanipuleerd dat het foerageren bemoeilijkt wordt en mezen andere gebieden dan schadegevoelige soorten zullen verkiezen. Door een 'slimme' inrichting kan het energetische voordeel van foerageren in een boomgaard worden verlaagd. Dat kan door voor mezen aantrekkelijk fruit ver van hun dekking (windsingels) aan te planten. Dit wordt ook wel aangeduid als het ruimtelijk bufferen van de kwetsbare fruitsoorten door aanplant van minder aantrekkelijke, zuurdere soorten (bijvoorbeeld Jonagold) direct naast de singels. Een andere mogelijkheid is het kort snoeien van windsingels, zodat de ze de mezen minder beschutting bieden (Dulos en Visser, 2006). Dat zorgt ervoor dat de balans van aantrekkelijk voedsel en predatierisico zo ongunstig wordt dat alternatieve foerageerplekken aantrekkelijker worden. Dit effect kan worden versterkt door het aanbieden van geschikte, alternatieve voedselplekken in de buurt, zodat de boomgaard als voedselbron minder belangrijk is (Bomford en Sinclair, 2002). In de praktijk kunnen mezen worden weggelokt door alternatieve voedselbronnen in de buurt, zoals zonnebloempitten. Dit soort toepassingen wordt in de praktijk wel toegepast (Dulos en Visser, 2006), maar ons zijn geen onderzoeken bekend die de effectiviteit van dergelijke maatregelen hebben geëvalueerd.

\subsubsection{Conclusies}

Schade door koolmees en pimpelmees (en zangvogels in het algemeen) wordt op dit moment het effectiefst bestreden door het (tijdelijk) plaatsen van netten of via akoestische of visuele afschrikeffecten. Over het algemeen kan wel gesteld worden dat netten goed werken, maar ze zijn kostbaar en alleen te overwegen bij een zeer hoge schadedruk. Bij minder hoge schadedruk lijkt het imiteren van predatoren het geschiktst, vooral in combinatie met akoestische technieken. Een alternatief, het aantrekken van - echte - predatoren, is nog weinig onderzocht, evenals habitatbeheer waarbij door ruimtelijke indeling de aantrekkelijkheid van schadegevoelige soorten verminderd wordt en waarbij alternatieve, niet-kostbare voedselbronnen in de nabije omgeving worden aangeboden.

Naast fysieke barrières zijn er een reeks visuele en akoestische verjaagmethoden die gebaseerd zijn op het creëren van een schrikreactie, zodat mezen naar elders uitwijken. Voor al die methoden geldt dat gewenning op de loer ligt en moet worden voorkomen. Dynamische methoden zijn effectiever dan statische; een combinatie van verjagingstechnieken is effectiever dan enkelvoudige technieken. Voorts is belangrijk dat verjaging vanaf vroeg in het seizoen plaatsvindt, om gewenning van terreinbezoek te voorkomen en daarmee ervoor te zorgen dat het terrein niet als voedselbron bekend wordt.

In tegenstelling tot fysieke barrières als netten is er een risico op gewenning aan visuele en akoestische methoden, die schadebestrijding kan ondermijnen of schade zelfs kan doen toenemen. De grotere spreiding van schade (bijv. meer appels of peren aangepikt) als gevolg van dergelijke inefficiënte verjaging kan zorgen voor een grotere totaalschade, vooral wanneer schimmels en insecten de schade die mezen hebben veroorzaakt, vergroten. Daar komt nog bij dat de energiebehoefte omhoog kan gaan bij voortdurende verstoring, wat ook de schade kan laten toenemen (Nolet et al., 2016 stelden dat voor ganzen vast). In dergelijke gevallen kan het verlies aan opbrengst zonder verstoring kleiner zijn door ernstige schade aan een kleiner aantal vruchten. Inefficiënte prikkels die tot gewenning leiden, zijn dus een punt van zorg bij het verjagen van mezen.

Er dient te worden opgemerkt dat het positieve effect van mezen, bijvoorbeeld door het verminderen van de aantallen rupsen, wegvalt bij effectieve verjaging. Wat de gevolgen zijn van het wegvallen van mezen voor de netto schadevermindering kan ook nog onderwerp van onderzoek zijn. 
Verjaagmiddelen mezen in het kort (bron: Buij et al., 2016)

\begin{tabular}{|c|c|c|c|}
\hline Middel & Effectiviteit* & Kosten & Toelichting \\
\hline Fysieke barrières & +++ & --- & $\begin{array}{l}\text { Over het algemeen effectief om mezen buiten te houden, } \\
\text { maar relatief duur. }\end{array}$ \\
\hline $\begin{array}{l}\text { Visuele verjaagmethoden: } \\
\text { Modellen: } \\
\text { Statisch } \\
\text { (vogelverschrikkers) } \\
\text { Dynamisch (vliegers) } \\
\text { Reflectoren }\end{array}$ & $0->++$ & $+->---$ & $\begin{array}{l}\text { Statische modellen zijn weinig werkzaam. Levensechte } \\
\text { modellen, die weinig voorspelbaar zijn in bewegingen en } \\
\text { locatie kunnen echter voor een respons bij zangvogels zorgen } \\
\text { die weken of maanden aanhoudt. }\end{array}$ \\
\hline $\begin{array}{l}\text { Visuele verjaagmethoden: } \\
\text { reflectoren }\end{array}$ & 0 & + & $\begin{array}{l}\text { Snelle gewenning treedt vaak op, vooral bij gebrek aan } \\
\text { beweging bij windstilte. }\end{array}$ \\
\hline $\begin{array}{l}\text { Akoestische verjaagmethoden } \\
\text { herrie } \\
\text { statisch } \\
\text { dynamisch } \\
\text { predatorgeluid }\end{array}$ & ++ & - & $\begin{array}{l}\text { Effectief als met goede geluidsopnamen wordt gewerkt, } \\
\text { waarbij gevarieerd wordt met de duur, locatie en tijd van de } \\
\text { geluiden, zoals alarmroepen, en wanneer aangevuld door } \\
\text { andere afschrikmiddelen. }\end{array}$ \\
\hline $\begin{array}{l}\text { Combinatie van visuele en } \\
\text { akoestische afschrikmiddelen }\end{array}$ & $+->+++$ & - & $\begin{array}{l}\text { Effectiefste, geteste methoden bij zangvogels, zeker bij een } \\
\text { combinatie van levensechte predatormodellen en } \\
\text { soortspecifieke, variërende alarmroepen. }\end{array}$ \\
\hline $\begin{array}{l}\text { Aantrekken/inzetten } \\
\text { predatoren }\end{array}$ & $+++?$ & +++ & $\begin{array}{l}\text { In potentie een kostenefficiënte en duurzame methode, maar } \\
\text { weinig empirisch onderzocht. }\end{array}$ \\
\hline Habitatbeheer & $+++?$ & +++ & $\begin{array}{l}\text { In potentie een kostenefficiënte en duurzame methode, maar } \\
\text { weinig empirisch onderzocht. }\end{array}$ \\
\hline
\end{tabular}

*) De effectiviteit is hier beoordeeld voor andere zangvogels dan mezen.

Voor mezen is de behoefte aan verbetering of ontwikkeling van verjaagmethoden hoog, want de schade door mezen aan fruitboomgaarden is vaak aanzienlijk en weinig verjaagmiddelen zijn specifiek getest op mezen. Bovendien zijn de meeste kostenefficiënte middelen, namelijk die zich richten op duurzaam verhogen van de predatiedruk in boomgaarden en het verminderen van de foerageerefficiëntie in de boomgaarden, nog nauwelijks op een gedegen manier getest. In onderstaande tabel staan suggesties voor het verder testen van bestaande - en nieuw te ontwikkelen methoden. Overigens is het raadzaam om bij het kwantificeren van het verminderen van de schade door mezen in boomgaarden ook het negatieve effect van het verlies van het onderdrukkende effect van mezen op rupsenschade te betrekken.

a) Testen van de effectiviteit van bestaande, potentieel geschikte middelen

- Er zijn voor mezen geen onderzoeken gedaan naar de efficiëntie van levensechte predatormodellen, waarbij visuele en akoestische methoden werden gecombineerd. In de absentie van roofvogels kunnen modellen effectief zijn, vooral levensechte, onvoorspelbaar bewegende modellen, omdat die de werkelijke predatoren het best imiteren. Onderzoek aan predatormodellen zou zich daarom vooral kunnen richten op levensechte, dynamische modellen.

\section{b) Ontwikkeling van nieuwe verjagingsmethoden}

- De effectiviteit van de aanwezigheid van levende roofvogels door middel van het plaatsen van nestkasten of zitplaatsen lijkt veelbelovend, omdat foerageerbeslissingen door mezen, net als bij andere vogels, voor een belangrijk deel worden bepaald door predatiegevoeligheid. Dergelijke middelen zijn bovendien relatief goedkoop, gemakkelijk inzetbaar, duurzaam en weinig milieubelastend. Ontwerpend onderzoek kan deze potentie zichtbaar maken. Het gaat dan vooral om het plaatsen van nestkasten en zitplaatsen voor torenvalk en andere roofvogels zoals buizerds. Gedacht kan worden aan een experimentele opzet waarbij schade door mezen wordt bepaald voor en na installatie van nestkasten en zitplaatsen, in vergelijking met controleboomgaarden (BACI).

- De effectiviteit van habitatbeheer dat ook de predatiegevoeligheid beïnvloedt, lijkt kansrijk. Aan dit onderwerp is bovendien ook nog nauwelijks onderzoek aan gedaan. Ontwerpend onderzoek kan ook deze potentie zichtbaar maken. Het gaat dan bijvoorbeeld om het effect van het bufferen van zoete fruitsoorten met zure soorten. Gedacht kan worden aan het experimenteel vergroten van de afstand van dekking (in windsingels) tot de zoete soorten, waardoor de afstand tot de dekking en de geprefereerde soort te groot wordt. Ook kan gedacht worden aan het verkleinen van de dekking door inkorten van windsingels. Het vergroten van voedselaanbod elders zal de afweging mogelijk sneller in het nadeel van foerageren in de boomgaard laten vervallen. Een experimentele opzet waarbij schade door mezen wordt bepaald voor en na zulk habitatbeheer en in vergelijking met controleboomgaarden zal dergelijk inzicht opleveren. 


\section{Grauwe gans, kolgans, brandgans en rotgans}

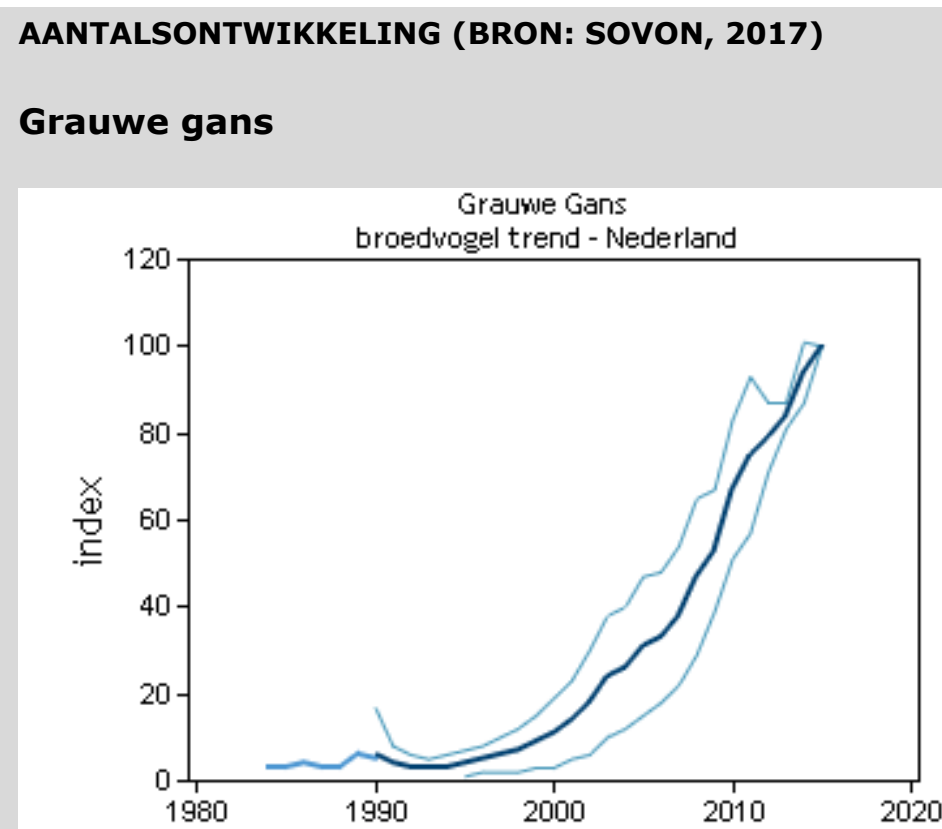

(9) Netwerk Ecologische Monitoring (Sovon, CBS)

De broedvogeltrend is gebaseerd op het Meetnet Broedvogels (BMP). Weergegeven is de jaarlijkse index van de broedpopulatie t.o.v. 1990 en de standaardfout.

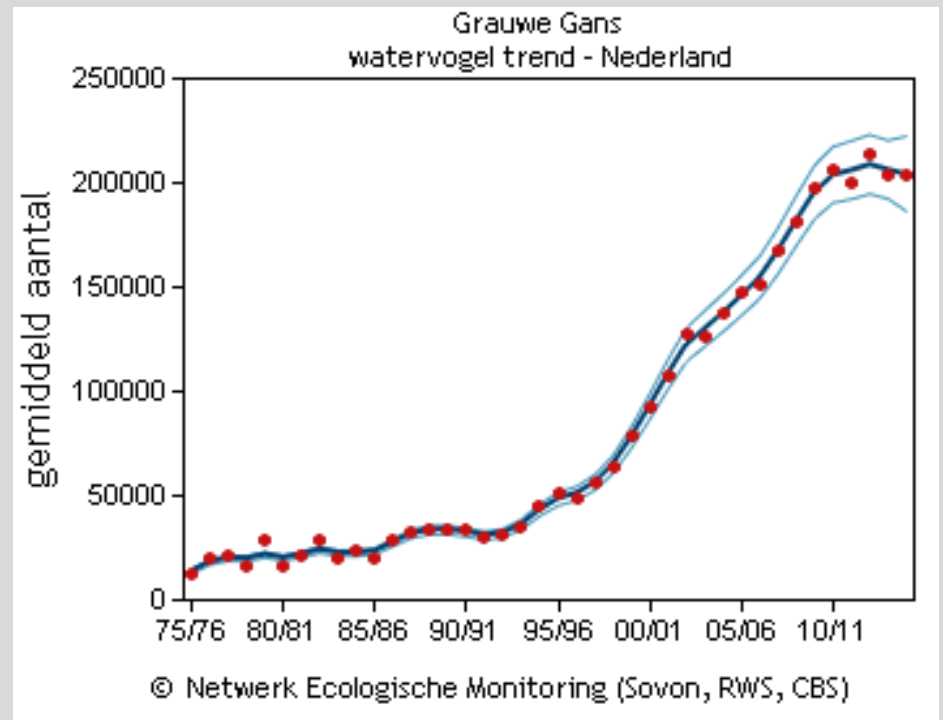

De watervogeltrend is gebaseerd op het Meetnet Watervogels (seizoen juli $t / m$ juni). Weergegeven is het seizoengemiddelde (rode punten), de trendlijn (donkergekleurde lijn) en het 95\%betrouwbaarheidsinterval van de trendlijn (lichtgekleurde lijn).

\section{Broedtijd}

In de eerste helft van de twintigste eeuw verdween de grauwe gans nagenoeg als broedvogel door ontginning van moerassen en bejaging. Uitzetpogingen leidden rond 1970 tot broedpopulaties in Friesland en het Deltagebied, gevolgd door een spontane vestiging in Flevoland. Daarna begon een periode van stormachtige uitbreiding, waarbij alleen de droge en bosrijke streken van Nederland werden overgeslagen. De aantallen broedparen namen toe van hooguit 150 in 1977 naar bijna 9000 in het jaar 2000 en een veelvoud nadien. 


\section{Buiten broedtijd}

De aantallen stegen vanaf 1975 enorm, een gevolg van de toegenomen Noordwest-Europese broedpopulatie inclusief de Nederlandse. De aantallen zijn het hoogst in najaar en winter, wanneer de omvangrijke eigen populatie (grotendeels standvogels) aanvulling uit Noord- en Oost-Europa krijgt. Rond 2010 ging het om maximaal een half miljoen grauwe ganzen, verdeeld over het hele land, maar met accenten in het Deltagebied en het rivierengebied. Streng winterweer heeft weinig effect op aantallen en verspreiding. In juni en juli ruien grauwe ganzen de slagpennen en zoeken ze veilige rietmoerassen op. Lange tijd fungeerden de Oostvaardersplassen als ruiplek voor tienduizenden vogels uit zowel Nederland als elders in Europa. Tegenwoordig ruien ook veel grauwe ganzen in de broedregio en is het aantal ruigebieden in heel Europa sterk gegroeid. Nog steeds ruien echter ook buitenlandse vogels in ons land.

\section{Kolgans}
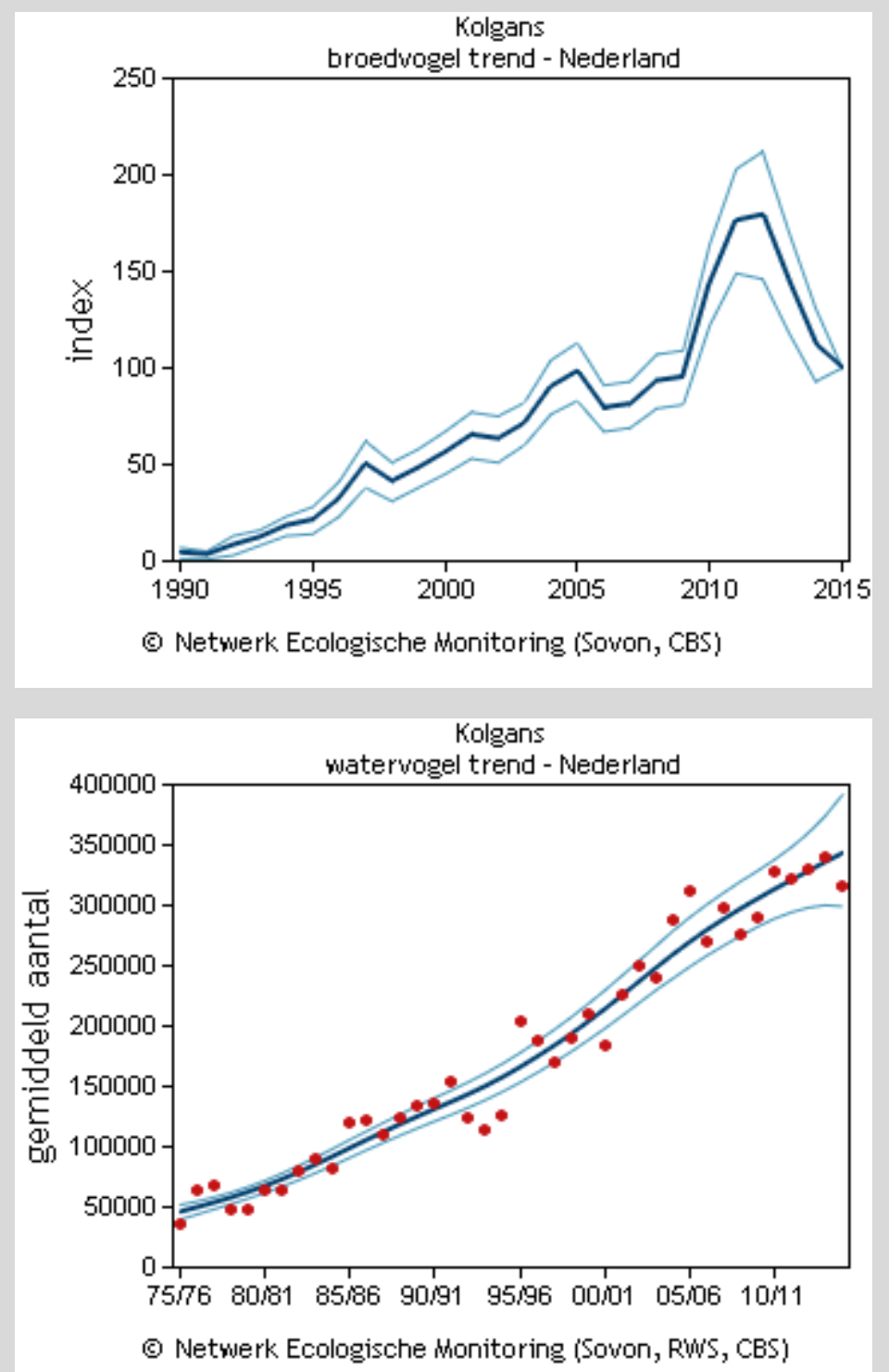

\section{Broedtijd}

Kolganzen broeden vanaf 1980 in ons land in snel toenemende aantallen. In eerste instantie ging het om lokvogels, gebruikt bij de jacht en losgelaten nadat dit middel verboden werd. De populatie groeide tot maximaal 250 paren rond 2000 en het drievoudige nog geen tien jaar later. Kerngebieden liggen rond de Friese Meren, in de Zaanstreek, oostelijk Zuid-Holland en het rivierengebied, vooral daar waar ook de meeste jagers actief waren. 


\section{Buiten broedtijd}

Kolganzen zijn voornamelijk aanwezig van oktober tot en met maart, met de hoogste aantallen midden in de winter. Maximaal vertoeven er bijna 900.000 kolganzen in ons land, $80 \%$ van de wereldpopulatie. De grootste concentraties houden zich op in graslanden in Friesland en het rivierengebied. Strenge vorst en zware sneeuwval kan leiden tot een leegloop uit Noordoost-Nederland (en toenemende aantallen in Zuidwest-Nederland en het rivierengebied), soms ook tot een massale toestroom of doortrek van vogels die eerst oostelijker pleisterden. De landelijke aantallen namen sinds 1975 fors toe. Dit berust deels op een herverdeling van binnen Europa overwinterende kolganzen en verlaagde jachtdruk. Tegelijkertijd arriveerde de voorhoede steeds vroeger en namen kolganzen nieuwe pleisterplaatsen buiten de traditionele in gebruik. Kolganzen blijven overigens niet langer hangen dan voorheen: in zachte winters trekt al een fors deel weg in februari. De in Nederland overwinterende aantallen zijn sinds 2005 stabiel; dat de seizoensgemiddelden nog toenamen, komt vooral doordat grote aantallen soms al vroeg in de herfst arriveren.

\section{Brandgans}
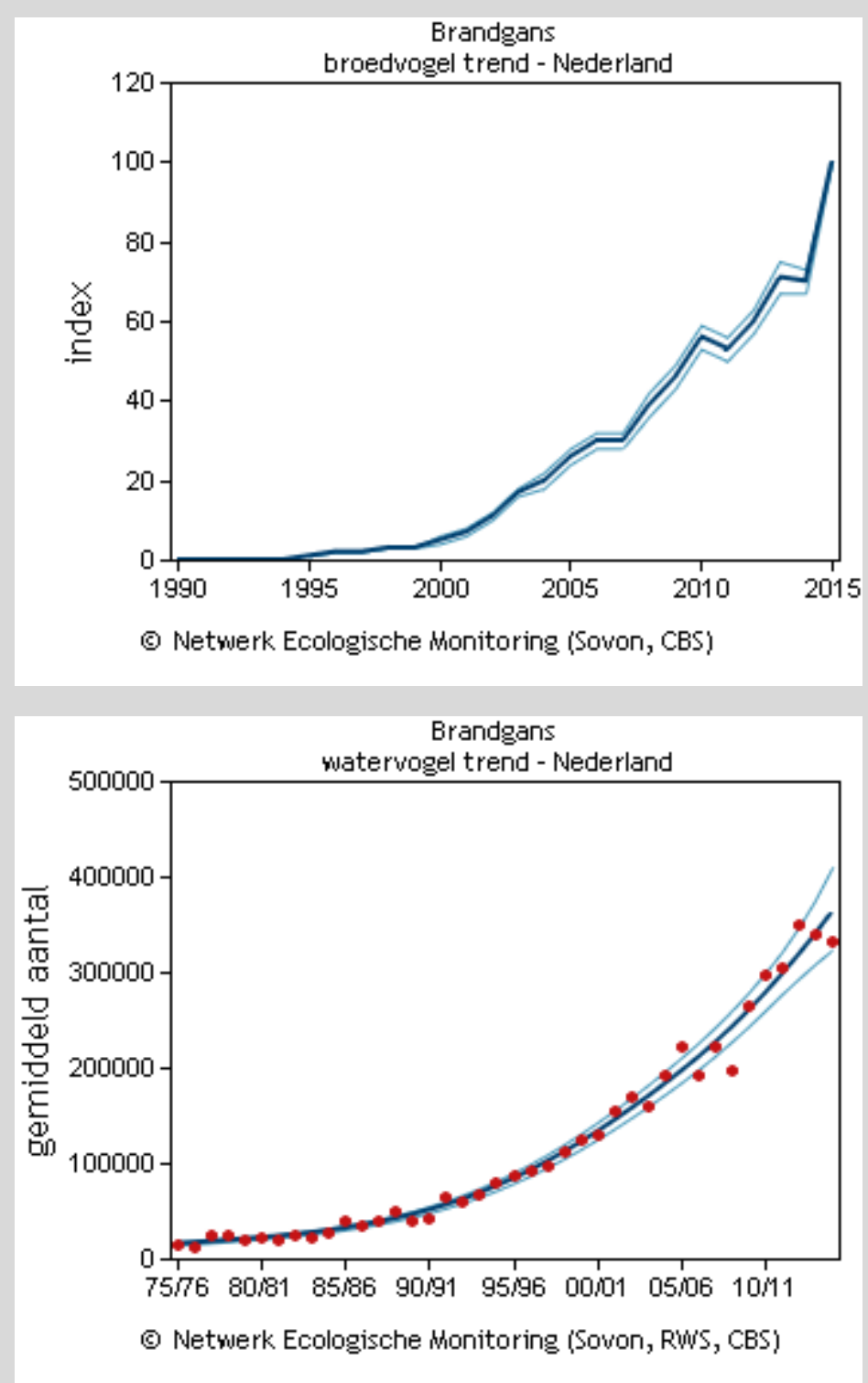

\section{Broedtijd}

Vanaf 1988 broeden er jaarlijks brandganzen in ons land, aanvankelijk alleen in het Deltagebied, daarna ook elders. De eerste vogels waren losgelaten of ontsnapt uit collecties, misschien ook achtergebleven zieke of gewonde trekkers. Daarna vestigde zich een snelgroeiende populatie (rond 1000 paren in het jaar 2000), met het zwaartepunt nog steeds in het Deltagebied. Het IJsselmeergebied en de Grote Rivieren nemen het leeuwendeel van de overige broedvogels voor hun rekening, maar de verspreiding breidt zich uit als bestaande kolonies hun piek bereiken. Brandganzen nestelen doorgaans kolonieachtig op veilige 
plekken, vaak eilanden of dammen. De toename bij ons vond plaats in een periode waarin de brandgans een spectaculaire toename kende in het Oostzeegebied en in Rusland. Ringmeldingen tonen aan dat er uitwisseling bestaat tussen Nederlandse broedvogels en die uit de Duitse Waddenzee, het Oostzeegebied en Rusland.

\section{Buiten broedtijd}

De brandgans is op weg om de kolgans voorbij te streven als talrijkste, in Noordwest-Europa overwinterende gans. Ook in Nederland zijn de aantallen enorm gestegen, met in sommige winters meer dan 800.000 exemplaren, overeenkomend met $80 \%$ van de fly-way-populatie. De verspreiding bleef tot rond 1990 sterk beperkt tot Friesland en het Wadden-, IJsselmeer- en Deltagebied. Daarna veroverde de brandgans ook het binnenland. Hier neemt hij, in tegenstelling tot de kustgebieden, nog steeds toe. Piekaantallen in het binnenland worden doorgaans in de nawinter geteld. Koud winterweer leidt tot enige herverdeling binnen ons land: relatief lage aantallen in Noord-Nederland en relatief hoge aantallen in het zuidelijke deel.

\section{Rotgans}

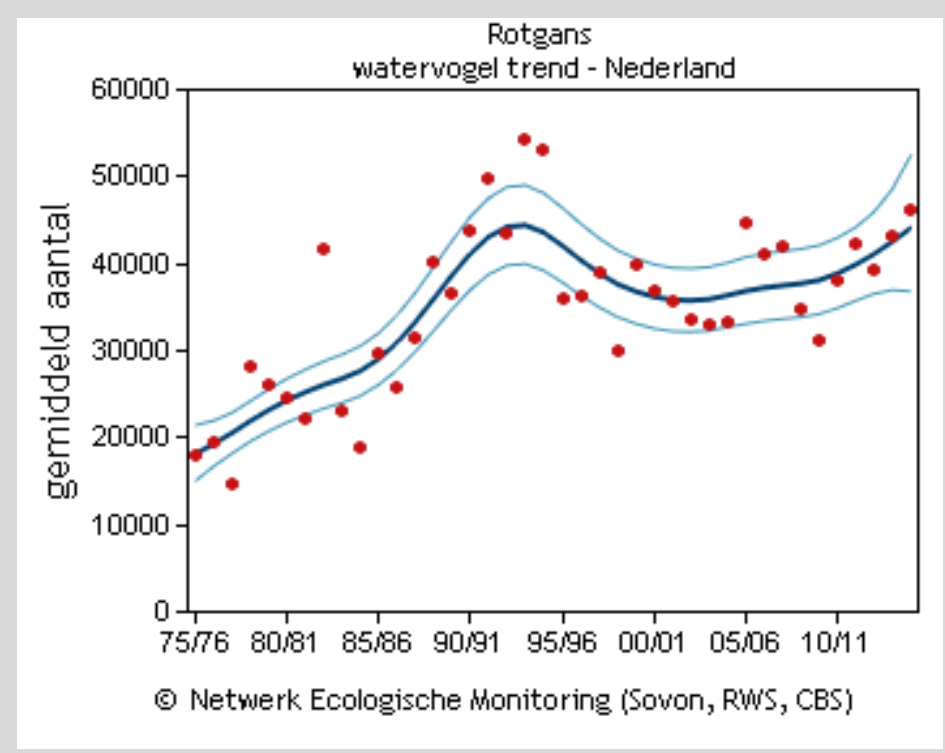

\section{Buiten broedtijd}

Uitzonderingen daargelaten, arriveren rotganzen vanaf eind september in ons land en vertrekken ze eind mei of begin juni. De soort is sterk aan zoute wateren gebonden en is in het diepe binnenland ronduit schaars. In het Waddengebied pieken de aantallen in het voorjaar, wanneer tot 100.000 rotganzen opvetten voor de terugkeer naar de broedgebieden. In het Deltagebied overwinteren tot 20.000 rotganzen en blijven de aantallen het hele winterhalfjaar op hetzelfde niveau. De landelijk getelde aantallen namen toe tot ongeveer 1995. Vervolgens vielen ze wat terug en bleven ze op lager niveau schommelen. De schommelingen houden voornamelijk verband met goede of slechte broedseizoenen, die veel of weinig jongen opleveren. Na 1995 is de kenmerkende afwisseling van goede en slechte broedjaren doorbroken door het wegvallen van de lemmingcyclus in de broedgebieden.

\section{Ontwikkeling als schadesoort}

De afgelopen jaren is er sprake van een sterke stijging van de uitgekeerde schade die werd toegeschreven aan ganzen (Fig. 2), overeenkomend met de sterk groeiende winter- en broedpopulaties. Hierbij kan worden aangetekend dat over de relatie tussen aantallen ganzen en schade door verlies aan biomassaoogst nog grote onzekerheid bestaat (vooral op de relevante, perceelschaal; Fox et al., 2017) en dat uitgekeerde schade niet overeen hoeft te komen met daadwerkelijke schade door de manier waarop schade opgenomen wordt bij taxatie. Vooral voor grauwe ganzen worden hoge schadebedragen uitgekeerd. Verhoudingsgewijs worden voor brandgans en kolgans, maar vooral rotgans veel minder hoge totaalbedragen uitgekeerd. De schade die werd toebedeeld aan deze soorten, was $84,4 \%$ van de totale schade toegekend aan de top 10 -soorten. Met $€$ 
$53,2 \mathrm{mln}$ toegekeerde schade is de grauwe gans landelijk de belangrijkste schadesoort in 2000-2016, gevolgd door kolgans ( $€ 19,2 \mathrm{mln}$ ), brandgans ( $€ 16,4 \mathrm{mln}$ ) en rotgans ( $€ 6,3 \mathrm{mln}$ ). Alleen voor mezen werd meer schade uitgekeerd dan voor rotgans.

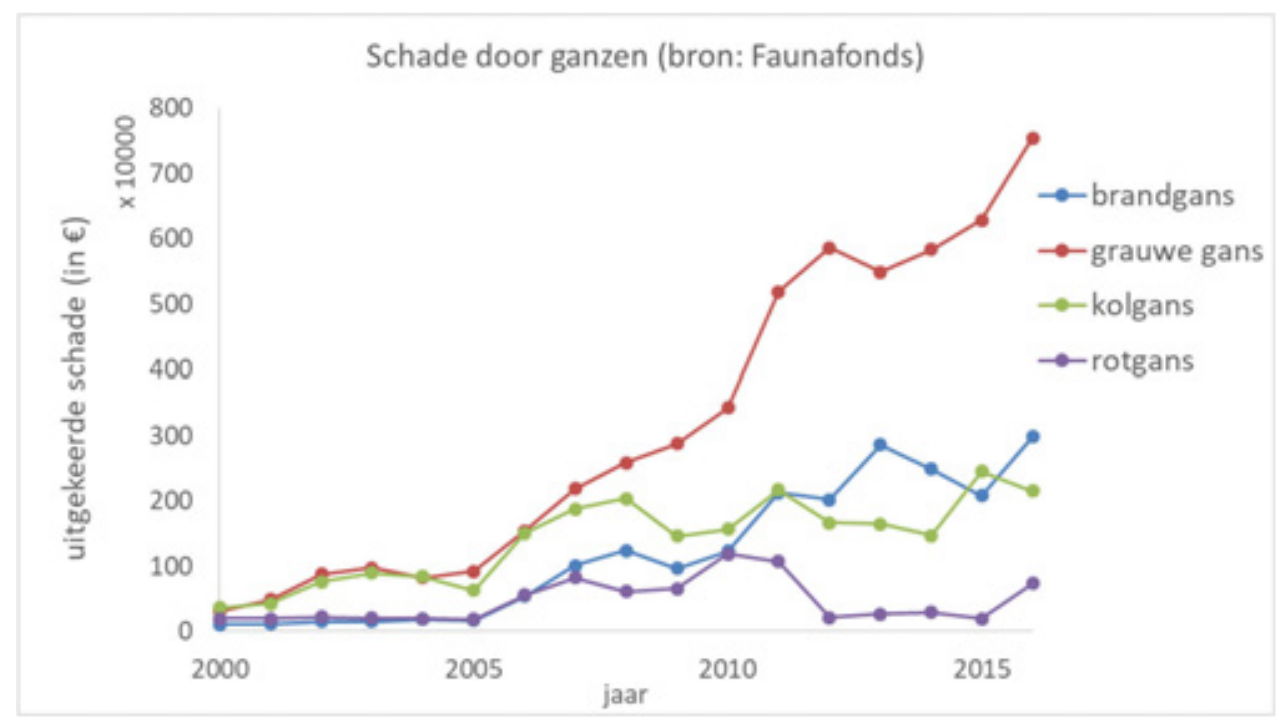

Figuur 2 Bedrag (in €) uitgekeerd voor schade toegekend aan ganzen gedurende 2000-2016.

\section{Positieve effecten voor de landbouw}

Bemesting door ganzenuitwerpselen zou een positief effect kunnen hebben, maar over het algemeen is er geen sprake van een substantieel effect op grasland of wintertarwe (Groot Bruinderink, 1989). Omdat ganzen selectief grazen en hun uitwerpselen relatief veel onverteerd plantenmateriaal bevatten, zijn hun uitwerpselen wel aantrekkelijk voor grazers zoals schapen en koeien, zoals op Schotse eilanden is vastgesteld (Ingram, 1933). In de praktijk zal dit nauwelijks tot niet bijdragen aan productie (Fox et al., 2017), hoewel er op dit punt sprake is van kennishiaten, met name in relatie met de nu veel hogere ganzendichtheden dan ten tijde van de bulk van het onderzoek hierover. Dit onderzoek kan zich dan richten op de relatie tussen ganzen, schade en bemesting; en bij welke dichtheden of seizoenen (schade in de winter is veel minder groot dan in voorjaar; Fox et al., 2017) het effect van ganzenbegrazing positief of negatief is.

\subsection{Belangrijkste werings- of verjagingsmiddelen}

Omdat middelen voor verschillende soorten ganzen dezelfde werkzaamheid kunnen hebben en veel middelen zijn getest op enkele soorten (vooral Canadese gans), zijn hier grauwe, kol-, brand- en rotgans samen behandeld. Uiteraard kunnen er dan nog verschillen optreden in de werkzaamheid van technieken, afhankelijk van de soort, het seizoen en de beschikbaarheid van soortspecifieke uitwijkmogelijkheden zoals opvanggebieden in de omgeving.

\subsubsection{Fysieke barrières}

Fysieke barrières, zoals rasters, kunnen worden gebruikt om geschikt foerageergebied - zoals stikstofrijke graslanden - onbereikbaar te maken voor ganzenfamilies met niet-vliegvlugge jongen (Voslamber, 2010). Met een dergelijk raster worden twee doelen beoogd: (1) minder schade door ganzen in landbouwgebieden grenzend aan broedhabitat en (2) verminderde jongenoverleving (en daarom populatieafname) door toegangsbeperking tot nutriëntrijk opgroeihabitat in landbouwgebied. Voslamber (2010) testte de effectiviteit van deze methode gedurende drie jaren in natuurgebieden met nesthabitat omringd waren door landbouwgrond. Door het plaatsten van een $50 \mathrm{~cm}$ hoog raster op de kade rond het natuurgebied moesten jonge grauwe ganzen het met het niet bemeste, natuurlijke grasland doen. Hierdoor werd voor ganzenfamilies het landbouwgebied onbereikbaar (en dus ging de landbouwschade bijna naar nul) en nam jongenoverleving af. Onduidelijk is wat dit voor effect op de lokale populatie had, bijvoorbeeld door afname van rekrutering van nieuwe broedvogels. Ook liet de 
effectiviteit van het raster nog te wensen over (o.a. omdat jongen passeerden door mazen, knaagschade door hazen).

\subsubsection{Visuele verjaagmethoden}

\section{Vogelverschrikkers}

Ganzenschade kan worden voorkomen door de inzet van verschillende visuele middelen zoals tape, ballonnen, vlaggen en vogelverschrikkers. Vaak gebruikte methoden zoals vlaggen en ballonnen (die worden voorgeschreven als randvoorwaarde om voor schadevergoeding in aanmerking te kunnen komen), zijn vaak niet effectief, of alleen wanneer ze zeer regelmatig van positie veranderen (Fox et al., 2017). Toch zijn er uitzonderingen, zoals bij sneeuwganzen waarbij schade significant lager was op percelen met witte vlaggen dan op controlepercelen zonder vlaggen (Mason et al., 1993). Naast vlaggen wordt tape regelmatig ingezet in een poging ganzen te weren van schadegevoelige percelen. Kosteneffectieve verjaging van rotganzen uit velden van wintertarwe kan bijvoorbeeld worden bereikt door lange lijnen tape over het veld te plaatsen (Summers en Hillman, 1990) en bij grauwe ganzen die grasland percelen met geelzwarte plastic merktekens (Van Liere et al., 2004) of holografische strippen (Kampen, 2006) vermeden. Hierbij lijkt op de langere termijn wel gewenning plaats te vinden en gaan ganzen toch over tot het begrazen van de percelen met tape, maar soms in lagere dichtheden dan in jaren wanneer tape niet werd gebruikt (Summers en Hillman, 1990).

Bij het gebruik van vlaggen kan de kleur mogelijk van belang zijn voor het effectiever maken van de methode. Watervogels hebben een kleurvisie die vergelijkbaar is met die van mensen en oranje is mogelijk de meest aversieve kleur voor ganzen (Lipcius et al., 1980), maar Heinrich en Craven (1990) constateerden dat de kleur van de vlag minder belangrijk was dan het verplaatsen van de vlaggen bij het verjagen van ganzen. Vaak wordt verondersteld dat het opzichtig ophangen van een dode vogel bij percelen tot eenzelfde vluchtrespons leidt, maar hiervoor is weinig bewijs. Seamans en Bernardt (2004) deden bijvoorbeeld experimentele studies tijdens het broedseizoen om te bepalen of Canadese ganzen werden afgeschrikt door een dode gans opgehangen aan een stok. Er was geen verschil in het gemiddelde aantal ganzen tijdens, voor en na de getrachte verjaging met een dode gans, na ongeveer 5 dagen. Dit laatste suggereert dat de aanwezigheid van de dode gans niet werd geassocieerd met de aanwezigheid van een predator, althans niet met een predatiedruk die zo hoog was dat de ganzen konden worden geweerd.

Een probleem met de traditionele vogelverschrikkers is waarschijnlijk ook dat ze vaak statisch zijn, op dezelfde plekken blijven en niet voor een schrikrespons zorgen die een langdurig effect heeft. Bewegende vogelverschrikkers kunnen wel de effectiviteit van andere verjaagmethoden vergroten (Inglis, 1980; Conover, 1985), vooral als die vogelverschrikkers een geweer lijken te dragen. Het ligt voor de hand dat dergelijke meer levensechte modellen de door ganzen ondervonden predatiedruk versterken, waardoor ze sneller geneigd zijn om te verkassen naar andere percelen.

\section{Laserstralen}

Verjaging met lasers is een potentieel bruikbare techniek om ganzen te verjagen. Licht is de belangrijkste stimulus die vogelgedrag en fysiologie beïnvloedt als het gaat om de broedcyclus, migratie, vetdepositie en rui bij de meeste soorten (Klem, 2007). Het ligt dan ook voor de hand dat de gevoeligheid van vogels voor licht gebruikt kan worden bij verstoring van foeragerende ganzen op landbouwvelden. Lasers bundelen licht dat zeer gericht ingezet kan worden met als doel het foerageergedrag van ganzen te beïnvloeden. Het concept om vogels te verjagen met een laser is 30 jaar geleden al ontwikkeld (Lustick, 1973), maar heeft maar weinig gedegen tests bij ganzen ondergaan zoals control-impact studies met een voldoende grote steekproef. De werkzaamheid over grote afstand, stilte en mogelijkheid om ze te richten op vogels, maken hand-gehouden en vaste lasers potentieel wel een zeer goed alternatief voor andere verjagingsmiddelen.

Recent is in Noord-Nederland een onderzoek uitgevoerd naar de effectiviteit van lasers bij het verjagen van ganzen (brandgans, Canadese gans, grauwe gans, kolgans, nijlgans, toendrarietgans) van percelen in de zomer en in de winter (Latour en Stahl, 2018). De studie toonde in de zomer een significante vermindering van de aanwezigheid van ganzen (gemeten op basis van ganzenkeuteltellingen) en de daaruit voortvloeiende fysieke vraat aan gras op percelen die voorzien zijn van een permanente laser 
ten opzichte van referentiepercelen zonder laseropstelling. Op basis van dit resultaat concluderen de auteurs dat het met de vaste laseropstelling mogelijk is om schade door ganzen te beperken in de zomerperiode. In de winter is een vaste laseropstelling geschikt om ganzen te verjagen op bewolkte dagen. Op zeer zonnige dagen is de verjaageffectiviteit beduidend lager en kan de schade alleen verminderd worden als er aanvullende maatregelen voor (reguliere) verjaging worden getroffen. Overigens concluderen de auteurs dat het effect van de laser zicht beperkt tot het betreffende perceel; de schade op gebiedsniveau blijft gelijk of neemt zelfs toe, omdat de ganzen zich naar elders verplaatsen. Verder blijkt uit het onderzoek ook dat andere vogels dan ganzen, zoals weidevogels, een duidelijk vluchtrespons vertonen op laserlicht. Inzet van lasers in gebieden met bijvoorbeeld hoge aantallen (broedende, foeragerende, doortrekkende) weidevogels wordt daarom afgeraden, wat de toepassing van lasers gedurende een groot deel van de zomer beperkt tot gebieden met weinig verstoringsgevoelige soorten.

Andere proeven met lasers vonden in gevangenschap plaats. In een dergelijk gecontroleerd experiment met Canadese ganzen in gevangenschap ( 6 groepen, 4 vogels per groep) werd extreme vermijding van plekken vastgesteld na gebruik van een laser. De ganzen werden gedurende perioden van 20 minuten onder schemercondities blootgesteld aan de laser, waarna $96 \%$ van de vogels zich verplaatsten zich naar de controleplekken zonder laser (Blackwell et al., 2002). De vraag is natuurlijk of dit effect ook zichtbaar is bij wilde ganzen. Cepek et al. (2001) testten een Laser DissuaderTM om Canadese ganzen weg te jagen bij een vaste slaapplek op een meer. Blootstelling gedurende 4 nachten resulteerde in een afname van 18,000 tot 1,600 individuen op het meer. Enkele dagen later was nog steeds maar $18 \%$ van de eerdere aantallen aanwezig. Deze testen zijn indicatief voor de potentie van laserstralen bij het voorkomen van schade door ganzen, tenminste wanneer de laser in donkere of schemeromstandigheden wordt gebruikt. Wel ligt het voor de hand dat laserstralen, net als maatregelen als afschot, vergassen, en weren met akoestisch middelen, ook effect hebben op andere soorten die gebruikmaken van dezelfde percelen en vogels die bij schemer actief zijn, zoals uilen. Bij een evaluatie van de effectiviteit van laserstralen voor het weren van ganzen van schadegevoelige percelen hoort daarom ook de evaluatie van de effecten van het gebruik van lasers op andere soorten.

\subsubsection{Akoestische verjaagmethoden}

Naast visuele verjaagmethoden kan het gevoelde risico dat ganzen ondervinden tijdens het begrazen van percelen ook verhoogd worden door het afspelen van alarmroepen van soortgenoten, waardoor de nabijheid van een predator wordt gefingeerd. Onderzoek naar het effect van het afspelen van alarmroepen op de verjaging van ganzen hebben echter gemengde resultaten opgeleverd (bijv. Mott en Timbrook, 1988; Aguilera et al., 1991; Whitford, 2009).

De vraag is of harde alarmroepen een ander effect hebben dan ander hard geluid. Aguilera et al. (1991) vergeleken daarom de effecten op ganzen van harde geluiden van granaten met alarmroepen van ganzen. Ze vonden dat hard geluid in ieder geval het best werkt als het frequent en onvoorspelbaar wordt ingezet. De gebruikte alarmroepen hadden echter nauwelijks effect en hoewel groepen wel alert werden bij afspelen, verlieten ze het foerageergebied niet. Dit suggereert dat harde geluiden effectiever zijn dan alarmgeluiden. Mott en Timbrook (1988) vonden verder een $71 \%$-afname in het gebruik van een gebied door ganzen, en een 96\%-afname in aantallen ganzen, als alarmroepen werden gebruikt in combinatie met harde geluiden, zoals een granaatknal. Dit onderzoek werd verricht door op de ganzen af te rijden tijdens het afspelen van de playback, waardoor het onduidelijk is wat de werkelijke reden was van de afname: de geluiden of het naderende voertuig. In ieder geval vlogen de verjaagde ganzen relatief kleine afstanden weg en keerden de ganzen snel terug toen de verjaging met akoestische middelen werd gestopt. Daaruit blijkt dat de duur van het effect en de ruimtelijke impact beperkt was.

Mogelijk speelt gewenning aan alarmroepen een rol bij het gebrek aan een verjagingseffect, tenminste op de lange duur. Bij het testen van het zogenaamde GooseBuster-apparaat in de VS was het streven om dergelijke gewenning te voorkomen (Whitford, 2008). De auteurs gebruikten alarmroepen gekoppeld aan harde knalgeluiden om Canadese ganzen te verjagen. Het verschil tussen dit onderzoek en ander onderzoek naar tape playback van alarmroepen (bijv. Mott en Timbrook, 1988; Aguilera et al., 1991) was dat de roepen zeker alarm- of alerterende roepen waren gebaseerd op degelijk en langlopend gedragsonderzoek. Bovendien werd gewenning voorkomen door geluiden alleen af te spelen in de aanwezigheid van de ganzen. Het succes van het GooseBuster-apparaat werd geëvalueerd op 
basis van het aantal ganzenuren voor en na applicatie van de methode, in combinatie met tellingen van ganzen en uitwerpselen. Het aantal ganzenuren per maand nam af van $>36,000$ tot $<200$, een $99,45 \%$-afname na gebruik van het apparaat. Hoewel het effect op schadereductie niet onderzocht was, werden er geen aanwijzingen gevonden voor gewenning gedurende de 100 dagen van de studie. Dit suggereert dat de methode efficiënt was, ook op de langere termijn. Het succes van deze test suggereert dat niet alleen de onvoorspelbaarheid, maar ook de kwaliteit van de opnamen een groot verschil maken bij de totstandkoming van een verjagingseffect. Het gaat er dan vooral om dat de alarmroepen die worden afgespeeld dezelfde soort betreffen als de soort die verjaagd wordt. Ook heeft onderzoek laten zien dat soortspecifieke alarmroepen minder hard hoeven te zijn dan alarmroepen van andere soorten, waarvan gebruik kan worden gemaakt voor het verminderen van de geluidsoverlast (Slater, 1980).

\subsubsection{Combinatie van visuele en akoestische verjaagmethoden}

Net als bij mezen werkt intensieve verjaging met combinaties van verjaagtechnieken vaak beter om ganzen te verjagen dan individuele verjaagmethoden (York et al., 2000; Drake en Villano, 2005; Holevinski et al., 2007; Radtke en Dieter, 2011). Verjaging met bordercollies en op afstand bestuurbare boten was bijvoorbeeld een effectiever verjaagmiddel dan bordercollies ${ }^{1}$ alleen of nachtelijke lasers (Holevinski et al., 2007). Een andere studie met gaskanonnen en linten als werende middelen in Schotland, waarbij om de paar dagen verjaagd werd met ondersteunend afschot, leverde een $50 \%$ afname van ganzenaantallen op (Percival et al., 1997). Door Bos en Stahl (2003) werden de effecten van verjaging met vogelverschrikkers, vlaggen en vuurpijlen op brandganzen in 1998 en 1999 vergeleken met twee jaren waarin de ganzen niet verjaagd werden (2000 en 2001). Per seizoen werden gemiddeld 160 pijlen afgeschoten. De gevolgen van de actieve verjaging waren dat brandganzen vroeger in het seizoen de agrarische percelen verruilden voor de kwelders (medio februari). In jaren zonder de verjaging was het aantal ganzen in de agrarische percelen aan het eind van het winterseizoen significant hoger dan in jaren met intensieve verjaging. De aantallen ganzen op de kwelders in het voorjaar waren gelijk in verjaag- en gedoogjaren, wat suggereert dat de kwelders ook zonder verjaging al maximaal benut werden.

Hoewel frequent verjagen van belang is om effectief te zijn, kan een toenemende frequentie van verjaging ook zorgen voor juist meer schade (Nolet et al., 2016). Dit lijkt paradoxaal, maar is het niet: de energiebehoefte door verjagen neemt toe en die wordt gecompenseerd door een hogere consumptie van gewas per tijdseenheid. De extra foerageertijd die nodig is om te compenseren voor verstoringen, hangt sterk af van de frequentie van de verstoringen en de daaropvolgende duur van de vlucht. Bij kolganzen bijvoorbeeld zal bij een verjagingsfrequentie van vijfmaal per dag de compensatie voor de hogere energiebehoefte leiden tot een toegenomen grasconsumptie van $11-16 \%$ per dag (Nolet et al., 2016). Belangrijk voor het slagen van een intensief verjagingsprogramma is in dat geval dus vooral ook de aanwezigheid van nabijgelegen opvanggebieden met minder kostbare 'offergewassen' als alternatief voor de gebieden waarin ganzen verjaagd worden (Fox et al., 2017).

\subsubsection{Verjaging met predatoren}

Belangrijke predatoren van ganzen zijn mensen ${ }^{2}$, roofvogels en carnivoren. Bij het verjagen van ganzen kunnen deze predatoren worden ingezet om schade te verminderen.

\section{Verjaging door mensen}

Mensen kunnen ganzen van percelen verjagen, waarbij de duur van het effect afhangt van de frequentie waarmee dat gebeurt. Met een experimentele opzet is in Denemarken getest welke verjaagfrequentie het effectiefst was bij kleine rietganzen (Simonsen et al., 2016). De ganzen werden tot 2, 5, 7 of 10 keer per dag verjaagd door mensen naar willekeurige percelen, waarbij groepsgrootte, vluchtafstanden en wekelijkse dichtheden in kaart werden gebracht. Tegelijkertijd werden ook dichtheden bepaald waar niet werd verjaagd. Twee keer verjagen liet geen verandering van aantallen zien, maar 5, 7 en 10 keer verjagen per dag zorgde voor een 74-78\%-daling van de aantallen, wijzend op een effectieve verjagingsfrequentie tussen de 2 en 5 keer per dag. Verjagen gedurende 6 dagen per week door één persoon op een quad was eveneens effectief om schade te reduceren door rotganzen in

\footnotetext{
1 De effectiviteit van inzet van honden wordt in 2.1 .5 besproken.

2 Het gaat hier om de mens in zijn ecologische rol, dus met of zonder geweer.
} 
Norfolk (Vickery en Summers, 1992). Ganzen werden verjaagd zodra ze landden op de kwetsbare gewassen, in dit geval wintertarwe en koolzaad. De ganzen waren nog zelden te vinden op de gewassen na een maand van intensief verjagen, behalve gedurende een uitzonderlijk strenge winter in 19901991. De intensiteit en duur van begrazing door ganzen op het wintergewas was bovendien lager in vergelijking met voorgaande jaren toen meer conventionele technieken (gasgeweer, vogelverschrikker, gekleurde vlaggen) werden gebruikt en linten werden gespannen over gewas, waarbij ook afschot werd gepleegd. Vooral ook van belang was de relatieve kostenefficiëntie van de methode, ook al was voortdurende aanwezigheid van één persoon nodig om het succesvol te laten zijn.

Verjaging met ondersteunend afschot is mogelijk effectiever dan verjaging zonder afschot vanwege de afschrikkende werking van afschot en de associatie die ganzen daardoor leggen met niet-dodelijke verjaagmiddelen. Eerdere studies suggereren inderdaad dat verjaging met ondersteunend afschot een groot effect kan hebben op het ruimtelijk landgebruik van ganzen (Ebbinge, 1991; Kleijn et al., 2009). Naast het effect van doding op soortgenoten is de manier waarop afschot plaatsvindt van belang en dan vooral de voorspelbaarheid. Over het algemeen is mobiel afschot effectiever dan afschot dat constant is vanaf een of enkele vaste locaties. Madsen (1995) documenteerde het effect van afschot bij twee experimentele gebieden in Denemarken om de hypothese te testen dat vogels een andere distributie zouden aannemen na jachtdruk en het instellen van rustgebieden. In beide gebieden nam de dichtheid toe in de rustgebieden, onafhankelijk van de locatie en andere omgevingsfactoren. De diversiteit van soorten en hun aantallen namen toe in de rustgebieden, wat suggereert dat het maken van rustgebieden niet alleen noodzakelijk is om een alternatief foerageergebied aan te bieden, maar ook effectief kan zijn om vogels te concentreren.

Niet altijd is daadwerkelijk afschot nodig om de suggestie bij ganzen te wekken dat een gebied onveilig is. Alleen de suggestie van afschot kan al effectief zijn bij verjaging, bijvoorbeeld wanneer losse flodders worden gebruikt en vooral in een vroeg stadium waarin ganzen de percelen net ontdekt lijken te hebben (Kemper, 1995). Voor maximale effectiviteit dient het schieten dan in hetzelfde gebied als de verjaging met overige middelen plaats te vinden (Inglis, 1980).

\section{Verjagen door honden}

Honden worden regelmatig ingezet om ganzen van percelen te verjagen. Hiervoor zijn bordercollies bijzonder geschikt. Castelli en Sleggs (2000) onderzochten het gebruik van bordercollies om Canadese ganzen te verjagen. Dit programma was succesvol, hoewel het slechts lokaal getest is. De auteurs vonden dat het jaarrond, 24 uur per dag verjagen van ganzen met honden kan leiden tot een $100 \%$ afname van ganzen op percelen. Als collies percelen bezochten met een frequentie van 4,7 keer per dag gedurende de herfst leidde dat tot een 68\%-afname van het aantal ganzen na een aantal weken. $\mathrm{Na}$ het stoppen van de verjaging herstelden de aantallen zich echter na 1 week tot de aantallen van voor de verjaging, wat suggereert dat het effect weliswaar groot, maar slechts kortstondig is.

In Zuidwest-Friesland is buiten de begrensde ganzenfoerageergebieden een proef gedaan met verjaging van ganzen door bordercollies (Oord et al., 2011). Hiervoor meldden zich 37 grondgebruikers met een gezamenlijke oppervlakte van ca. 1711 ha. Op deze gronden heeft vanaf begin oktober 2009 tot en met 30 april 2010 intensieve verjaging met bordercollies plaatsgevonden. In totaal vonden er 787

verjaagacties plaats. De studie vond dat ganzen vaak nog dezelfde dag terugkeerden naar percelen, na het verdwijnen van de hond, hoewel de verjaagde ganzen de verjaagpercelen (op den duur) wel leken te mijden. De kans dat een gemerkte kleine rietgans die eenmaal in een verjaaggebied was gezien daar ook binnen hetzelfde seizoen nog een keer werd gezien, bleek tijdens de bordercollieproef veel lager te zijn dan in voorgaande seizoenen (Oord et al., 2011): lag deze kans in de drie winters voorafgaand aan het bordercollieproject rond de 55-60\%, in het jaar dat met bordercollies werd verjaagd was die kans ruim gehalveerd tot $23 \%$. Het lijkt er dus op dat er wel een effect van het verjagen met bordercollies is opgetreden, en dat daardoor de kleine rietganzen veel minder geneigd waren terug te keren naar de gebieden waarvandaan ze verjaagd werden. Het gebruik van bordercollies is dus in potentie een geschikte methode om ganzen te verjagen, zij het dat het effect meestal kortdurend, arbeidsintensief en dus kostbaar is. 


\subsubsection{Habitatbeheer}

Omdat de distributie van ganzen net als bij andere soorten een afweging is tussen predatiedruk en foerageerkwaliteit, kan habitatbeheer gebruikt worden om predatierisico te verhogen, bijvoorbeeld door aanleg van bosjes of houtwallen die predatoren gebruiken voor dekking. Tegelijkertijd kunnen voedselgebieden waar ganzen wel kunnen foerageren, zoals opvanggebieden, door habitatbeheer aantrekkelijker worden gemaakt (Fox et al., 2017). Dit kan worden bewerkstelligd door toevoeging van nutriënten aan die lokgewassen, het beheer van grashoogte om percelen aantrekkelijk te maken voor ganzen - zowel uit oogpunt van voedselkwaliteit als predatorontwijking - en het aanbieden van waterplassen in de buurt van de alternatieve voedselgebieden.

Ganzen selecteren het minst vezelrijke voedsel met het hoogste proteïne-/energiegehalte in de grootste hoeveelheden, dicht bij slaapplekken en waar rust gegarandeerd wordt. Een goede manier om ganzen weg te houden van schadegevoelige percelen is daarom het aanbieden van voedsel met een hogere kwaliteit maar minder kostbaar gewas (als alternatief voedselgebied), in de buurt van een slaapplek (Owen, 1977; Fox et al., 2017). De gewassen die als alternatief worden gezaaid, kunnen betere kwaliteit bieden dan de gevoelige gewassen, met een snellere hergroei-capaciteit. Tegelijkertijd kan het aanbieden van minder gevoelig grassoorten de schade mogelijk helpen verminderen. Het kan dan gaan om grassen die voor runderen wel, maar voor ganzen niet aantrekkelijk zouden zijn. Van 'Green Spirit', een tetraploid van Engels raaigras met ruwe textuur, wordt wel beweerd dat die deze eigenschappen heeft, wat bij ons weten nog niet is aangetoond. Aan de andere kant kunnen ganzen ook van kostbare, gevoelige gewassen weggelokt worden door het aanbieden van gewassen met een hoog proteïne-, energie- en watergehalte en hoge verteerbaarheid. Het toevoegen van additionele nutriënten kan hierbij ook nog helpen (Percival, 1993; Patterson en Fuchs, 2001). De selectie van voedsel is ook afhankelijk van het seizoen. Terwijl in voor- en najaar het proteïnegehalte van belang is, is tijdens de winter energieopname van belang. De alternatieve afweer- of weglokgewassen zouden dus moeten inspringen op voedselbehoefte in een bepaalde tijd van het jaar, bijvoorbeeld eiwitrijk voedsel in vooren najaar, energierijk voedsel in de winter en voor migratie (Fox et al., 2017).

Bij het aanbieden van foerageergebied dient meegewogen te worden dat ganzen de energetisch gunstiger gebieden zoeken, waarmee de pendelvluchtafstand tussen slaap- en foerageergebieden geminimaliseerd kan worden. Ganzen zullen dus sneller geneigd zijn de gebieden dichter bij slaapplekken, zoals waterplassen, te gebruiken dan gebieden van vergelijkbare geschiktheid op grotere afstand (Fox et al., 2017). Velden met alternatieve gewassen waarop ganzen kunnen foerageren zijn 5 ha of groter, met voldoende zicht, uit de buurt van wegen, dicht bij roestgebieden en zonder verstoring (Fox et al., 2017). Als de gebieden kleiner zijn, neemt het (gevoelde) risico op predatie toe en wijken ganzen uit naar meer open gebieden waar een predator op grotere afstand ontdekt kan worden.

In Nederland laat de effectiviteit van opvanggebieden te wensen over (Koffijberg et al., 2017). Bij een evaluatie van maandelijkse tellingen van 4 ganzensoorten gedurende 10 jaar voorafgaand aan het opvangbeleid en in de 8 jaar na implementatie bleek dat evenveel gansdagen (57\%) binnen de opvanggebieden werd besteed voor als na de implementatie. Een dergelijk gebrek aan herverdeling van ganzen suggereert geen voorspelde leereffecten, mogelijk te wijten aan een populatietoename van ganzen gedurende de duur van studie, ruimtelijk grillig begrensde opvanggebieden, met enclaves van niet-opvanggebied (met een verjaagregime, dat ook binnen het opvanggebied verstoort).

Van de afweging tussen predatiedruk en voedselgeschiktheid kan ook gebruikt worden gemaakt door gebieden met kwetsbare gewassen te verkleinen tot minder dan 5 ha, door aanplant van houtwallen of andere landschapselementen. Overigens dient dit met zorgvuldigheid gedaan te worden, omdat dergelijke elementen ook de habitatgeschiktheid voor bijvoorbeeld weidevogels als de grutto negatief kunnen beïnvloeden. Aan de andere kant kan aanplant van kleinschalige landschapselementen gunstige effecten hebben op weer andere soorten.

\section{Chemische afweerstoffen}

De foerageerhabitat van ganzen kan ook beïnvloed worden door het aanbrengen van chemische afweerstoffen op en rond kwetsbare gewassen. Er zijn maar weinig chemicaliën die ganzen succesvol afschrikken en waar dat wel zo is, is het niet of moeilijk te combineren met de veehouderij. Onderzoek in Nederland wees uit dat grauwe ganzen niet minder van gras eten dat met actieve kool (Norit in 
water) is behandeld dan van controlepercelen (Liere et al., 2004). Het sproeien van een suspensie van actieve houtskool was wel effectief (tot 16 dagen na sproeien) om begrazing door sneeuwganzen (Chen caerulescens) te verminderen (Mason en Clark, 1995), maar de intensiteit van besproeiing maakt dit een dure methode. Diazinion, een organofosforisch insecticide, is effectief bevonden om schade te verminderen aan grasland door Canadese ganzen, maar bleek fataal te zijn voor Amerikaanse smienten (Anas americana; Kendall et al., 1992, 1993). Dergelijke chemicaliën zijn niet goedgekeurd voor gebruik in Europa. Natuurlijk voorkomende plantaardige producten of hun derivaten kunnen een oplossing bieden, maar ook hier bestaan problemen met betrekking tot schade aan andere vertebraten en de Europese regelgeving. Onderzoek laat zien dat methylantranilaat (MA) en cinnamamide effectief kunnen zijn in het verminderen van schade door Canadese en sneeuwganzen (Cummings et al., 1991; Mason en Clark, 1995). Tijdens commercieel productonderzoek in de VS zijn producten zoals Rejex-IT en Goose Chase, die MA als hun actieve ingrediënt hebben, naar verluidt effectief bij het verminderen van de voedingsactiviteit op gras. MA is een derivaat van druivensap, wordt veel gebruikt in de VS en heeft een bittere smaak. Het wordt beschouwd als onschadelijk in de VS, maar kan negatieve effecten hebben op vogels. Cinnamamide (uit kaneel) is in het Verenigd Koninkrijk onder licentie getoetst, maar het is onwaarschijnlijk dat er voldoende markt voor het product is om verdere ontwikkeling te garanderen.

\subsubsection{Conclusie}

Dat ganzen een afweging maken tussen het maximaliseren van voedselopname en minimaliseren van predatiedruk (of verstoring) is vaak gedemonstreerd en hiervan kan gebruik worden gemaakt om verjaging efficiënter te maken (bijv. Madsen, 1985; Bélanger en Bédard, 1989; Gill et al., 1996). De beste manier om schade te verminderen, is om de ganzen naar minder kwetsbare of economisch minder waardevolle gewassen te leiden (Owen, 1977; Van Eerden, 1990). Het ligt dan voor de hand om tegelijkertijd de energetische kosten van het grazen op kwetsbare gewassen te vergroten, bijvoorbeeld door frequente verstoring of het veinzen van predatiedruk, waardoor het minder winstgevend wordt om op de kwetsbare gewassen te foerageren (Fox et al., 2017).

Ganzenschade kan worden voorkomen door verschillende verjaagtechnieken die voor (gevoelde) predatiedruk of verstoring zorgen, zoals visuele middelen, akoestische stimuli, op de grond of in de lucht, of een combinatie van die middelen. In de praktijk wordt vaak een combinatie van middelen getest. Het gaat dan om middelen die meestal op een predator lijken, zoals een mens of een roofvogel, of middelen die de suggestie wekken dat een predator in de buurt is, zoals door het afspelen van alarmroepen. Om dezelfde reden is de werkzaamheid van middelen die een dergelijke associatie niet oproepen (zoals statische vlaggen) waarschijnlijk laag.

Net als bij mezen is gewenning de belangrijkste factor die de efficiëntie van akoestische verjaagmiddelen beperkt. Intensieve, regelmatige, voorspelbare stimuli zorgen voor gewenning, wat niet mogelijk is met plotselinge afschrikking. Dit verklaart o.a. de gewenning aan constante verstoring zoals op drukke vliegvelden, waar vogels foerageren in de nabijheid van frequente, harde geluiden. Over het algemeen zijn verstoringen die vroeg optreden, wanneer ganzen nog niet in een dagelijkse routine van foerageren zitten, het effectiefst (Radtke en Dieter, 2011). 
Verjaagmiddelen ganzen in het kort (bron: Buij et al., 2016)

\begin{tabular}{|c|c|c|c|}
\hline Middel & Effectiviteit* & Kosten & Toelichting \\
\hline $\begin{array}{l}\text { Fysieke barrières: } \\
\text { rasters }\end{array}$ & $+(++) ?$ & variabel & $\begin{array}{l}\text { Mogelijk alleen effectief als grote gebieden worden } \\
\text { afgerasterd. Effect op populatie onduidelijk. }\end{array}$ \\
\hline Akoestische verjaagmethoden & $0 /+++$ & variabel & $\begin{array}{l}\text { Gemengde resultaten, maar succesvol voor } \\
\text { langeretermijnverjaging als soortspecifiek alarmroepen } \\
\text { worden gebruikt en alleen als ganzen daadwerkelijk } \\
\text { aanwezig zijn op percelen, zodat gewenning voorkomen } \\
\text { wordt. }\end{array}$ \\
\hline $\begin{array}{l}\text { Combinatie van visuele en } \\
\text { akoestische verjaagmethoden }\end{array}$ & $+/+++$ & variabel & $\begin{array}{l}\text { Intensieve verjaging met een combinaties van } \\
\text { verjaagtechnieken werkt vaak beter dan enkele methoden. }\end{array}$ \\
\hline Habitatbeheer & $++?$ & + & $\begin{array}{l}\text { In potentie de duurzaamste methode, omdat de afweging } \\
\text { tussen predatiedruk en voedselgeschiktheid permanent } \\
\text { wordt beïnvloed. In combinatie met consequent verjagen bij } \\
\text { kwetsbare gewassen en rust bij opvang-/lok-gewassen. }\end{array}$ \\
\hline Chemische afweerstoffen & $0 /+$ & - & $\begin{array}{l}\text { Soms effectief, maar regelmatig schadelijk voor vee en } \\
\text { milieu. }\end{array}$ \\
\hline
\end{tabular}

*) testen van de effectiviteit zijn vaak uitgevoerd voor andere soorten ganzen dan grauwe gans, brandgans, kolgans of rotgans.

\section{Aanbevelingen voor aanvullend onderzoek}

Voor ganzen is de behoefte aan verbetering of ontwikkeling van verjaagmethoden groot, want de schade door ganzen neemt de laatste jaren snel toe (hoewel dit varieert tussen provincies en soorten) en afschot, afvangst en nestreductie zoals die in de Nederlandse praktijk kunnen worden gerealiseerd, zijn niet of nauwelijks effectief om populatiegroei en schade te verminderen (bijv. Stahl et al., 2013; Van der Jeugd en Kwak, $2015^{3}$ ). De implementatie van ganzenfoerageergebieden is tot nu toe niet effectief, vooral door imperfecte uitvoering: grilligheid/variatie in tijd en ruimte van de verjaaginspanning (Kleijn et al., 2008; Koffijberg et al., 2017). Het verdient aanbeveling opvang opnieuw te onderzoeken, met een betere uitvoering (Melman et al., 2017). Bovendien zijn de naar onze inschatting de meest kostenefficiënte middelen, namelijk die zich richten op duurzaam verhogen van de predatiedruk en het verminderen van de voedselopname, nog nauwelijks op een gedegen manier getest. Akoestische verjaagmethoden, of combinaties van visuele en akoestische verjaagmethoden, kunnen in potentie concurreren met de efficiëntie van dodelijke verjaging met ondersteunend afschot, waarvoor nu vaak wordt gekozen vanwege een verondersteld, maar niet bewezen effect op aantallen ganzen en/of schade (Koffijberg et al., 2017). De effectiviteit van die middelen, en vooral de intensiteit waarin ze dienen te worden ingezet, zijn echter onvoldoende beproefd.

${ }^{3}$ Deze onderzoeken zijn hier niet besproken, omdat deze middelen buiten het kader van verjagen vallen, het onderwerp van deze studie. 
Hieronder een aantal suggesties voor het verder testen van bestaande of vaak gebruikte methoden en de ontwikkeling van nieuwe methoden.

\section{a) Testen van de effectiviteit van bestaande, potentieel geschikte middelen}

- Akoestische verjaagmethoden, of combinaties van visuele en akoestische verjaagmethoden zijn in potentie zeer geschikte methoden, als tenminste kan worden voorkomen dat gewenning optreedt. Met een experimentele opzet kan getest worden welke intensiteit of verjaagfrequentie het effectiefst is bij welk middel (zie bijvoorbeeld Simonsen et al., 2016).

b) Ontwikkeling van nieuwe verjagingsmethoden

- Systemen die ganzen herkennen met audio en video zodat verjaging daadwerkelijk plaatsvindt wanneer ganzen aanwezig zijn, lijken zeer waardevol (bijv. Steen et al., 2014), omdat ze verjaging mogelijk maken wanneer ganzen aanwezig zijn en gewenning minimaliseren. Het verder testen van dergelijke methoden, in een BACI-ontwerp en in vergelijking met traditionele methoden, lijkt een voor de hand liggend onderzoek.

- De effectiviteit van lasers voor het verjagen van ganzen is nog weinig getest, ondanks de ogenschijnlijke potentie van deze verjagingsmethode. Hierbij dient ook het potentieel negatieve effect op andere soorten betrokken te worden.

- Tot op heden is te weinig onderzoek gedaan naar de effectiviteit van de ruimtelijke en temporele samenstelling van alternatieve foerageergebieden bij het weglokken van ganzen van schadegevoelige percelen. Het gaat dan vooral om gewaskwaliteit, nabijheid van water, en openheid van de gebieden. Als ingegrepen wordt in dergelijke landschapseigenschappen en de daarmee samenhangende afweging tussen predatiedruk en voedselkwaliteit, kan ganzen foerageren op een manier gestuurd worden die op de langere termijn effect heeft. Toekomstig onderzoek kan zich in dit verband o.a. richten op:

1. De effectiviteit van alternatieve foerageergewassen met snelle hergroei en verhoogd eiwitgehalte om ganzen weg te lokken van gevoelige gewassen.

2. Het testen van grassoorten die onaantrekkelijk zijn voor ganzen, maar wel door vee geconsumeerd worden.

3. De relatie tussen de nabijheid van roestgebied en gebiedsopenheid aan de ene kant, ganzenaantallen en schade op gevoelige percelen aan de andere kant en de effectiviteit van maatregelen die hierop ingrijpen.

4. Om te weten te komen of opvanggebieden voldoende alternatieve foerageergebied leveren en of optimalisatie van gewas en omgevingskenmerken kunnen bijdragen aan het ruimtelijk sturen van ganzen, zijn modelstudies zoals die van Baveco et al. (2011) te gebruiken. 


\section{Smient (winter)}

\section{AANTALSONTWIKKELING (BRON: SOVON, 2017)}

Smienten zijn het talrijkst in de maanden november tot en met maart, maar per winter treden er verschillen op. Bij de inval van strenge vorst en zware sneeuwval vertrekt een deel van de vogels naar Engeland of Frankrijk, in zachte winters blijven grote aantallen bij ons. Concentraties treden op zowel nabij zoute wateren (Waddengebied, deel van Deltagebied) als zoete wateren (open graslandpolders). De landelijk getelde aantallen namen tot ongeveer 1990 toe, maar dalen weer vanaf 2000. De recente daling staat waarschijnlijk in verband met een verschuiving van de winterverspreiding binnen Noordwest-Europa. Door gemiddeld zachtere winters blijft een deel van de vogels noordelijker overwinteren.

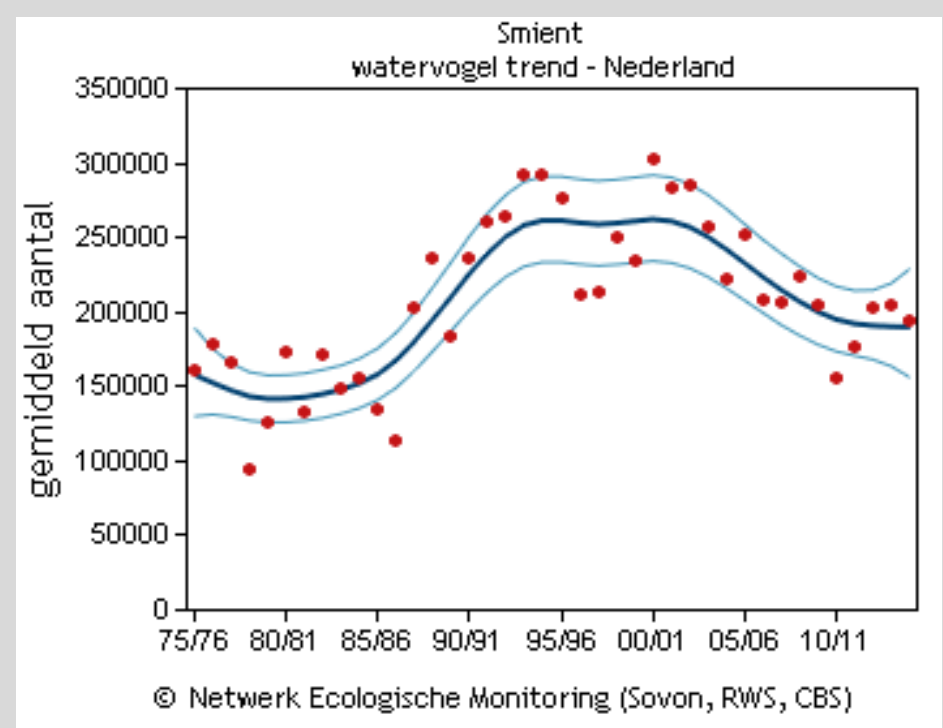

De watervogeltrend is gebaseerd op het Meetnet Watervogels (seizoen juli $t / m$ juni). Weergegeven is het seizoensgemiddelde (rode punten), de trendlijn (donkergekleurde lijn) en het $95 \%$ betrouwbaarheidsinterval van de trendlijn (lichtgekleurde lijn).

\section{Ontwikkeling als schadesoort}

Smienten zijn als schadesoorten vooral belangrijk in de winter en de kleine broedpopulatie wordt hier daarom buiten beschouwing gelaten. De afgelopen jaren is er sprake van fluctuaties, met een overall licht negatieve trend van de uitgekeerde schade die werd toegeschreven aan smienten (Fig. 3). In 2015/16 was er sprake van een stijging, waarbij de schade op het niveau op dat van 2000 zit. Het piekjaar was 2012 , toen er ca. $€ 0,5 \mathrm{mln}$ werd uitgekeerd aan smientenschade. Verhoudingsgewijs waren smienten met $€ 5,5 \mathrm{mln}$ toegekeerde schade verantwoordelijk voor ca. 4,5\% van de totale toegekeerde schade aan de top 10-schadesoorten sinds 2000 . 


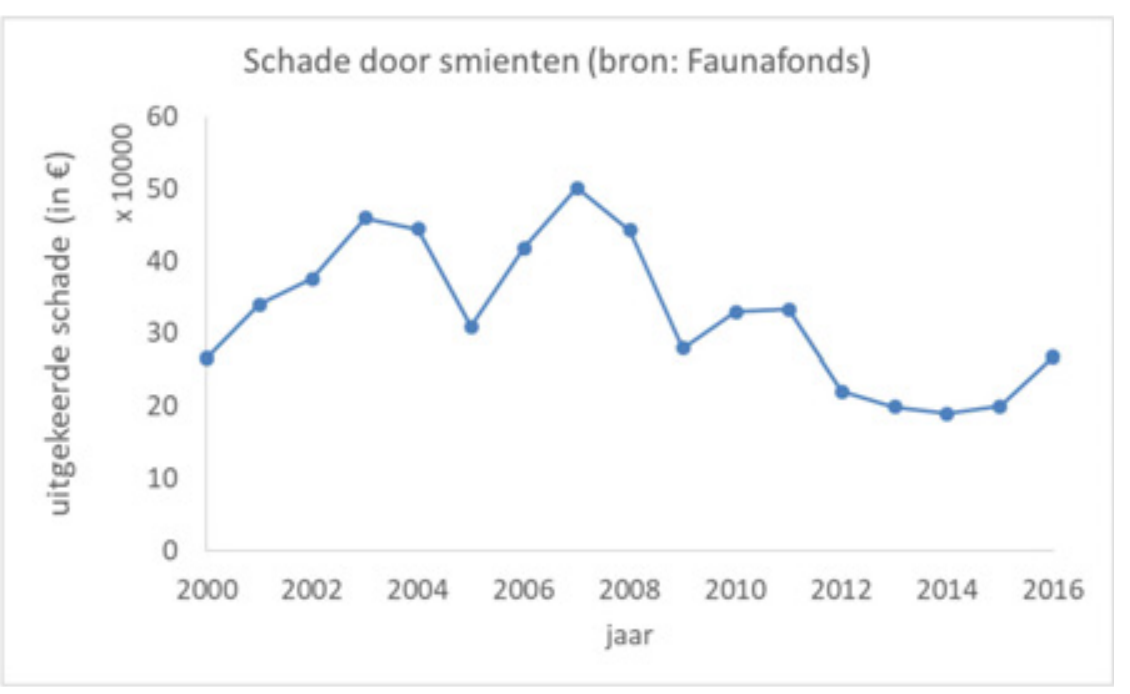

Figuur 3 Bedrag (in €) uitgekeerd voor schade toegekend aan smienten gedurende 2000-2016.

Positieve effecten voor de landbouw

Over het algemeen zal er net als bij ganzen nauwelijks sprake zijn van een belangrijk effect van bemesting door smienten (Groot Bruinderink, 1989; Fox et al., 2017).

\subsection{Belangrijkste werings- of verjagingsmiddelen}

\subsubsection{Visuele verjaagmethoden}

Hoewel er ook voor smienten vergelijkbare visuele verjaagmethoden voor te stellen zijn als voor ganzen, zijn er maar een paar getest. Net als bij ganzen is bij smienten de effectiviteit van vlaggen getest als verjaagmethode. Lichte, zwarte vlaggen waren bijvoorbeeld effectief bij het verminderen van begrazing door smienten 's nacht (Lane en Nakamura, 1996). In deze studie werd begrazing door smienten van een tarwegewas voorkomen door zwarte kunststofvlaggen $(0,3 \mathrm{~m} \times 3 \mathrm{~m})$ met een dichtheid van 50 vlaggen per ha te plaatsen en onbeschermde controlegebieden te verschaffen als alternatieve foerageergebieden. De opbrengstderving in de gebieden zonder vlaggen werd geschat op $83 \%$ van de opbrengst met vlaggen, op basis van het verschil in biomassa gewas binnen en buiten omheiningen. In gebieden met vlaggen kon geen opbrengstverlies worden vastgesteld. Het effect van de vlaggen werd toegeschreven aan de dynamische/veranderlijke schaduwen die door de wind gecreëerd werden. Smienten zouden als gevolg van de deze onrust vertrekken naar andere percelen. Overigens veronderstellen de auteurs dat het effect van de vlaggen kleiner zal zijn als er geen wind staat. Bovendien zal het verjagen nog efficiënter zijn als er in de nabijheid alternatieve foerageergebieden aanwezig zijn, de kans op gewenning aan de vlaggen is aanzienlijk als dat niet het geval is (Fox et al., 2017). Bij een experiment met holografische strippen om overdag foeragerende smienten te weren, bleek geen effect van de strippen te kunnen worden aangetoond (Kamp, 2006); bovendien breken de strippen snel waardoor hun effectiviteit op de langere termijn laag lijkt (Boudewijn et al., 2007).

\section{Lasers}

Lasers tegen begrazing door smienten zullen vooral in de schemering en 's nachts dienen worden ingezet wanneer smienten foerageren en het contrast tussen de laserstraal en natuurlijk licht voldoende groot is. Gedurende schemerlicht of donker weer is een laserstraal erg selectief, maar 's nachts reikt het licht over grotere afstanden en kan dan niet-selectief zijn (en bijvoorbeeld ook andere vogels, zoals eenden, uilen, of zoogdieren verjagen).

Er is relatief weinig onderzoek gedaan naar het effect van lasers op smienten, terwijl deze nacht-actieve eenden waarschijnlijk wel gevoelig zijn voor de lasers. Boudewijn et al. (2008) beschreven de reactie van smienten op lasers gedurende één nacht en concludeerden dat smienten vooral verstoord werden indien ze direct werden beschenen met een laser. De laser leek tot op een afstand van $400 \mathrm{~m}$ en mogelijk zelfs tot $800 \mathrm{~m}$ effectief in het verjagen van nachtelijk foeragerende smienten op één nacht, 
maar deze smienten dienden wel direct aangestraald te worden. Door het zeer verspreid voorkomen van de smienten diende het gehele gebied aangestraald te worden om de smienten effectief te kunnen verjagen. Op basis van de veldproef kan niet geconcludeerd worden of de beschenen percelen de gehele nacht smientvrij blijven.

\subsubsection{Habitatbeheer}

Net als bij ganzen kan de selectie van smienten van planten met een hoog proteïne-, energie- en watergehalte en weinig vezels, worden gebruikt bij het maken van alternatieve foerageergebieden (Fox et al., 2017). Ook is de gewashoogte van belang bij die selectie, smienten selecteren graslanden met kort gras. Op alternatieve percelen kan dan voedsel worden aangeboden dat aantrekkelijker is (hoog eiwit-, hoog energie-, laag vezelgehalte, hoge verteerbaarheid en laag gemaaid) dan de gevoelige percelen waarop schade dient te worden voorkomen. Hierbij kan ook gebruik worden gemaakt van het feit dat smienten open water in de buurt nodig hebben om predatie te ontwijken. Tot op heden is onderzoek naar de effectiviteit van dergelijke alternatieve gewassen schaars.

\subsection{Conclusie}

Smienten foerageren 's nachts op graslanden en de meeste middelen ter bestrijding van schade zullen logischerwijs dan ingezet worden. In tegenstelling tot andere schadesoorten is weinig empirisch onderzoek gedaan specifiek bedoeld om smientenschade beperken. De belangrijkste middelen lijken vlaggen, tape en lasers, samen met het aanbieden van alternatieve foerageergebieden in de buurt van water. Akoestische verjaagmethoden of combinaties van visuele en akoestische verjaagmethoden zijn in tegenstelling tot ganzen nauwelijks getest. Net als bij ganzen lijkt het zinvol om ze naar minder kwetsbare, minder economisch waardevolle gewassen te leiden (Owen, 1977; Van Eerden, 1990) en door verjaging/verstoring het foerageren op schadegevoelige gewassen minder winstgevend te maken (Fox et al., 2017). De effectiviteit van die middelen en vooral de intensiteit waarin ze dienen te worden ingezet, zijn echter onvoldoende onderzocht.

Verjaagmiddelen smienten in het kort (bron: Buij et al., 2016)

\begin{tabular}{llll} 
Middel & Effectiviteit & Kosten & $\begin{array}{l}\text { Toelichting } \\
\text { Vlaggen en tape }\end{array}$ \\
$\begin{array}{lll}\text { Effectief als vlaggen en tape in voldoende hoge dichtheden } \\
\text { worden ingezet en er sprake is van wind voor beweging van } \\
\text { de vlaggen. }\end{array}$ \\
\hline Laser & + & $-?$ & $\begin{array}{l}\text { Mogelijk effectief omdat smienten 's nachts actief zijn, maar } \\
\text { nog weinig getest. }\end{array}$ \\
\hline Habitatbeheer & $++?$ & + & In potentie effectief, maar nauwelijks empirisch getest. \\
\hline
\end{tabular}

\section{Aanbevelingen voor aanvullend onderzoek}

Smienten zijn vooral in de winter aanwezig. Het is een niet algemene soort, waarvan de aantallen omlaaggaan en waarvan de schade een gelijke trend heeft. Het is daarmee te overwegen of bestrijding nog aan de orde zou moeten zijn en schadecompensatie te continueren, zonder aantalsreductie. Om lokale schade te voorkomen, kunnen bestaande methoden verder geoptimaliseerd worden. De ontwikkeling van nieuwe methoden voor schadevermindering door smienten heeft minder prioriteit dan bij de meeste ganzensoorten. 


\section{a) Testen van de effectiviteit van bestaande, potentieel geschikte middelen}

- De effectiviteit van lasers voor het verjagen van smienten is nog weinig getest, ondanks de ogenschijnlijke potentie van deze verjagingsmethode.

\section{b) Ontwikkeling van nieuwe verjagingsmethoden}

- Systemen die smienten herkennen met audio en video, zodat verjaging dan plaatsvindt wanneer smienten daadwerkelijk aanwezig zijn (bijv. Steen et al., 2014), lijken zeer waardevol, zoals bij ganzen. Het testen van dergelijke methoden, in een BACI-ontwerp en in vergelijking met andere veel gebruikte methoden, lijkt een belangrijke stap voor verdere ontwikkeling.

- Akoestische verjaagmethoden of combinaties van visuele en akoestische verjaagmethoden zijn in potentie geschikte methoden, als tenminste kan worden voorkomen dat gewenning optreedt. Met een gedegen experimentele opzet kan getest worden welke intensiteit of verjaagfrequentie het effectiefst is bij welk middel (zie bijvoorbeeld Simonsen et al., 2016).

- Tot op heden is te weinig onderzoek gedaan naar de effectiviteit van de ruimtelijke en temporele samenstelling van alternatieve foerageergebieden bij het weglokken van smienten van schadegevoelige percelen. Het gaat dan vooral om gewaskwaliteit, nabijheid van water en openheid van de gebieden. Als ingegrepen wordt in dergelijke landschapseigenschappen en de daarmee samenhangende afweging tussen predatiedruk en voedselkwaliteit, kan foerageren op een manier gestuurd worden die op de langere termijn effect heeft. Toekomstig onderzoek kan zich in dit verband o.a. richten op:

1. De effectiviteit van alternatieve foerageergewassen met snelle hergroei en verhoogd eiwitgehalte om smienten weg te lokken van gevoelige gewassen. Experimenteel onderzoek met gewassen met verschillende vezelgehalten kunnen worden gebruikt om het potentieel van smaak te beïnvloeden, zodat smienten weggelokt kunnen worden van schadegevoelige percelen. Hierbij kan worden gedacht aan het ontwikkelen van specifiek 'offergewas' dat op een gegeven moment in de jaarcyclus past bij de behoeften van smienten in relatie tot gevoelige gewassen die dan ook beschikbaar zijn. Voorbeelden zijn meer eiwitrijke 'lokgewassen' in het voorjaar en de herfst of energierijke voeding in het midden van de winter.

2. Het testen van grassoorten die onaantrekkelijk zijn voor smienten, maar wel door vee geconsumeerd worden.

3. De relatie tussen de nabijheid van rustgebied en gebiedsopenheid aan de ene kant, smientenaantallen en schade op gevoelige percelen aan de andere kant en de effectiviteit van maatregelen die hierop ingrijpen. 
4. Das

\section{AANTALSONTWIKKELING}

Ontwikkeling als schadesoort

Sinds 2000 is er sprake van een stijgende trend van de uitgekeerde schade die werd toegeschreven aan dassen (Fig. 4). Toch valt de aan dassen toegekende schade nog steeds in het niet bij totale landbouwopbrengsten en in vergelijking met andere soorten die verantwoordelijk worden gehouden voor landbouwschade. Het piekjaar voor schade door dassen was 2015, toen er landelijk ca. $€ 178.000$ werd uitgekeerd. Verhoudingsgewijs waren dassen met maar $€ 1,5 \mathrm{mln}$ toegekeerde schade sinds 2000 slechts verantwoordelijk voor maar $1,2 \%$ van de totale toegekeerde schade aan de top 10schadesoorten.

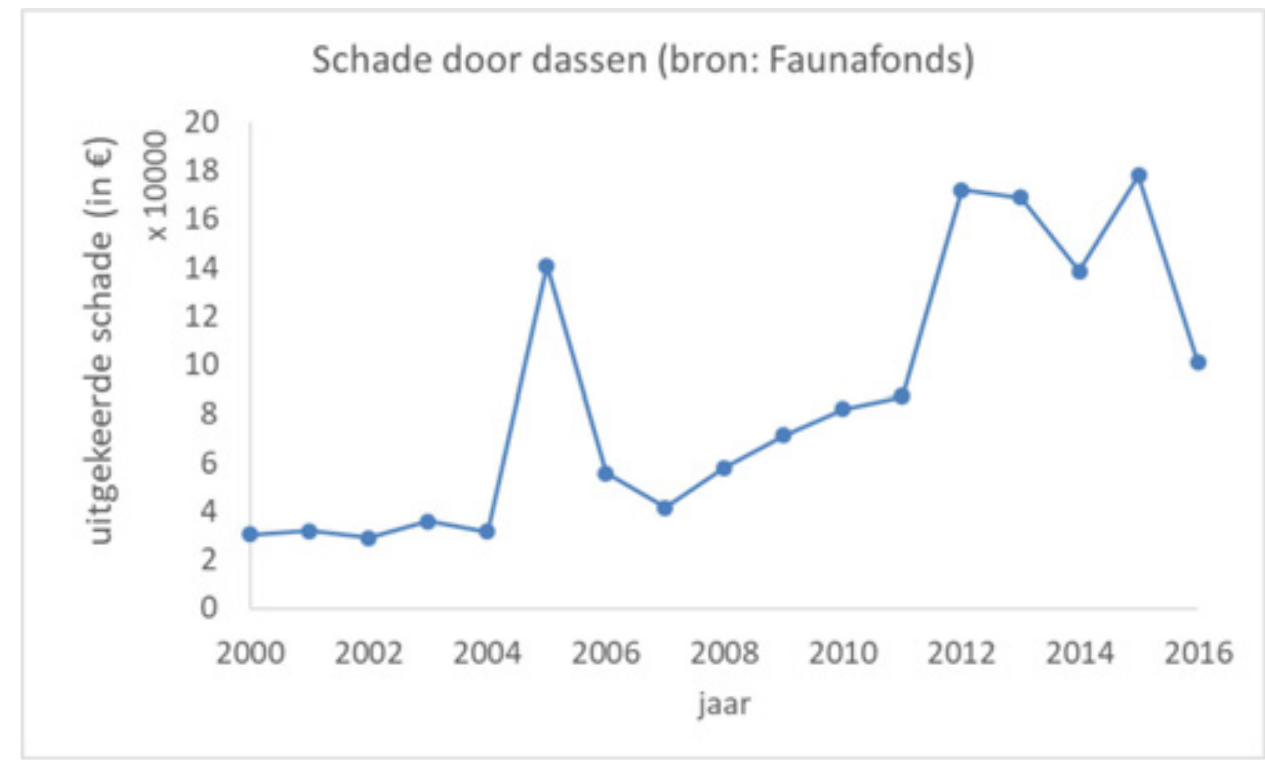

Figuur 4 Bedrag (in €) uitgekeerd voor schade toegekend aan dassen gedurende 2000-2016.

Positieve effecten voor de landbouw

Dassen eten plantaardig materiaal, zoals mais, eikels en fruit en dierlijk materiaal, zoals insecten(larven) nestjongen van konijnen en muizen, regenwormen en slakken (La Haye \& Vink, 2016; Faunaschade Preventie Kit. Module das., 2016). Het eten van insecten(larven), konijnen en muizen kan een positief effect hebben op schade in de landbouw.

\subsection{Belangrijkste werings- of verjagingsmiddelen}

Oord (2002, 2009) en Hollander en La Haye (2014) geven een overzicht van preventieve maatregelen per gewas niet voor de das, maar alleen voor het in schade-opzicht verwante wild zwijn, en bevat bovendien geen onderzoeksresultaten naar de effectiviteit. Hier ligt daarom de nadruk op resultaten uit buitenlands onderzoek.

\section{Verplaatsen van dassen}

Overlast van dassen kan effectief worden voorkomen door het verplaatsen van dassen en/of door de huidige burcht te barricaderen (Matthews en Wilson, 2005; Ward et al., 2016). Hiervoor is in Nederland uiteraard wel een ontheffing nodig, want de das is een beschermde soort volgens artikel 3.10 van de Wet natuurbescherming (Bijlage $A$ ), waarin staat dat het opzettelijk beschadigen of vernietigen van een dassenburcht niet toegestaan is, behalve als sprake is van een 'algemeen belang' of om belangrijke schade aan gewassen te voorkomen. Het ontoegankelijk maken van burchten is naar verwachting meestal ineffectief. Dassen zijn namelijk zeer plaatstrouw en maken in opeenvolgende generaties 
gebruik van dezelfde burchten, wissels en foerageergebieden (La Haye \& Vink, 2016; Hollander, 2016) en zullen dichtgegooide gangen weer open maken. Het barricaderen kan alleen effectief zijn als alle locaties waar burchten in kunnen worden gegraven anderszins ongeschikt worden gemaakt en het leefgebied als zodanig onaantrekkelijk wordt gemaakt.

Het verplaatsen van dassen is mogelijk door het aanbrengen van een raster met eenrichtingspoorten, waarbij de dassen de burcht wel in kunnen, maar niet meer uit. Hiermee kunnen alle dassen worden weggevangen, waarna de burcht onbewoonbaar wordt gemaakt. Onder bepaalde omstandigheden, zoals wanneer twijfel bestaat over het succes van het wegvangen, kunnen dassen ook voorzichtig uitgegraven worden (Davison et al., 2008). Het verplaatsen van dassen dient plaats te vinden naar geschikt leefgebied gelegen op een grote afstand, om te voorkomen dat de dieren terugkeren naar hun oude leefgebied. Ondanks het feit dat dergelijke verplaatsingen vele malen per jaar worden geprobeerd (o.a. in het Verenigd Koninkrijk), mislukt het vaak omdat dassen terugkeren na uitzetten (Davison et al., 2008; Ward et al., 2008; Delahay et al., 2009). Daarnaast zijn er welzijnsproblemen te verwachten voor de dassen en kan verplaatsing leiden tot schade aan gewassen in het gebied waarnaar ze verplaatst worden (DEFRA, 2006) en de schade per saldo gelijk blijft.

\subsubsection{Chemische afweermiddelen}

Chemische afweer richt zich op de gewassen zelf en zijn om deze reden te verkiezen boven het verstoren van burchten. Chemische middelen zijn regelmatig gebruikt om dassen te verdrijven en ook getest in Engeland (Baker et al., 2005a, b). Dergelijke middelen hebben irriterende eigenschappen en veroorzaken geconditioneerde smaakaversie. Deze kennis kan gebruikt worden voor het verminderen van schade aan schadegevoelig gewas. Chemische afweermiddelen zijn in beginsel niet dodelijk, maar zijn weinig onderzocht op schadevermindering.

Baker et al. (2005a) testten de relatieve effectiviteit van capsaïcine, cinnamamide en ziram in een meerkeuze 'cafetaria'-experiment voor dassen, waarbij behandeld en onbehandeld voedsel werd aangeboden aan individueel herkenbare dassen en met cameravallen gedetailleerde gedragswaarnemingen werden gedaan om te respons te scoren. De responsverschillen tussen de vier behandelingen waren groot. De voorkeur ging uit naar onbehandeld voedsel, gevolgd door voedsel behandeld met cinnamamide en capsaïcine en daarna ziram. De dassen leken een geconditioneerde smaakaversie te ontwikkelen tegen met ziram behandeld voedsel, met een sterkere afkeur na verloop van tijd. De aversie was dus gebaseerd op alleen de geur.

Ziram is een fungicide en wordt ook ingezet als afweermiddel tegen andere zoogdieren. Om maisgewas te beschermen zouden rond de dassenburcht in het maisgewas behandelde maiskolven gestrooid kunnen worden. Deze behandeling dient dan vooraf te gaan aan de voorspelde schadeperiode, zodat de smaakaversie zich voldoende vroeg in het groeiseizoen ontwikkelt en dassen op basis van de afstotende geur alle mais zullen vermijden. In een vervolgstudie kwantificeerden Baker et al. (2005b) de dosis waarop ziram effectief is op een vergelijkbare manier. Twee dassen lieten tijdens de studie een duidelijke dosis-afhankelijke response zien, met een plateau bij een ziram concentratie van $1,3 \%$ van het gewicht van maiskolven. Dit effect was duidelijk op basis van individuele gedragingen van dassen en schade bij behandelde kolven. Baker et al. (2005b) concluderen dat maiskolven behandeld dienen te worden met 1,3-1,5\% (van gewicht) ziram of een $10 \%$ (van volume) zirampasta.

Baker et al. (2008) testten als vervolg op hun studie ook de voedselaversie met behulp van een geurprikkel, alleen om onbehandelde gewassen te beschermen tegen dassen. Na het aanbieden van voedsel met een combinatie van ziram- en kruidnagelolie, meden de dassen de onbehandelde maiskolven in aanwezigheid van alleen de kruidnagelgeur. Training op kruidnagelolie alleen leverde niet een dergelijke respons. Kruidnagel heeft een neutrale geur, waarmee dassen konden worden geconditioneerd om onaangenaam voedsel behandeld met ziram te vermijden. De dassen associëren dan de ziramsmaak met ziekte en de aversie voor ziramsmaak kan weer worden gelinkt aan een aversie voor een geur die met ziram geassocieerd wordt, in dit geval kruidnagelolie. 


\subsubsection{Schrikdraad}

Om dassen te weren van schadegevoelige gewassen wordt ook schrikdraad ingezet (Poole et al., 2002; Tolhurst et al., 2008). Er zijn verschillende ontwerpen getest om dassen te weren. De laatste jaren zijn belangrijke stappen gemaakt in het perfectioneren van het ontwerp van de omheining en er zijn verschillende studies die de effectiviteit van verschillende typen bedradingen, elektrische ladingen en de duur van het effect van elektrische omheining op het voorkomen van dassenschade hebben gekwantificeerd. Wetenschappelijk onderzoek naar de effectiviteit is schaars, maar er zijn goede voorbeelden die de effectiviteit aantonen (Hollander, 2016).

Poole en McKillop (1999) testten de effectiviteit van een nieuw tweedraads ontwerp van geëlektrificeerde draad voor het uitsluiten van dassen. De auteurs vergeleken de effectiviteit van de draad met die van geëlektrificeerde netten, door het lokvoerverbruik of de schade aan het gewas vóór en na de omheining te vergelijken. Zowel de draden als de netten waren $95-99 \%$ effectief en deed het lokvoerverbruik of de gewasschade sterk afnemen in vergelijking met de controlesituatie (Poole en McKillop, 1999). De meerderheid van de dassen vermeed het raster en werd na het plaatsen zelden meer gezien bij de elektrische omheining. De omheiningen hadden geen invloed op de tijd die de dassen 's nachts actief waren of waar ze sliepen gedurende de dag. Dit wijst erop dat het een effectieve, diervriendelijke methode is om dassenschade effectief te verlagen.

Poole et al. (2004) testten ook de efficiëntie van het type draad op het reduceren van dassenschade: staaldraad en meerdradig geleidend draad met plastic draden (zogenaamd 'polydraad').

Voedselverbruik door 24 dassen werd dagelijks gedurende 2 weken geregistreerd op 4 x $4 \mathrm{~m}^{2}$ percelen en gescoord als 0 (geen), 1 (gedeeltelijk) of 2 (compleet). Na de periode van 2 weken waarin de dassen gewend werden aan het voedsel, werd 1 van de 2 gepaarde plots toegewezen aan een behandeling, de andere plot was een controleplot. De effectiviteit van zowel stalendraad- als polydraadomheining die op $6 \mathrm{kV}$ werden gehouden, werd vergeleken met die van draad waarop de spanning werd verhoogd, in 2 kV stappen, van 0 tot $6 \mathrm{kV}$. De effectiviteit werd gemeten door het voedselverbruik vóór en na de omheining van het voedsel te vergelijken. Zowel de stalendraad- als de polydraadhekken die op $6 \mathrm{kV}$ in stand gehouden werden, bleken effectief te zijn bij het uitsluiten van dassen, terwijl niet-geactiveerde hekken $(0 \mathrm{kV})$ vrijwel geen bescherming opleverden. Naarmate de spanning toenam, was er een overeenkomstige toename van het niveau van effectiviteit. Bij elke spanningsfase bleek het stalen draadhek effectiever te zijn dan zijn polydraad tegenhanger. De resultaten suggereren dat grondeigenaars die het gebruik van elektrische hekwerken gebruiken om dassen uit te sluiten beter staaldraad dienen te gebruiken in plaats van polydraadomheiningen. Bovendien zouden draadspanningen niet onder $4 \mathrm{kV}$ mogen dalen, vooral gedurende de eerste paar weken na opstellen, omdat dassen anders lijken te wennen ook aan schokken bij hogere spanning. Poole et al. (2004) lieten tot slot zien dat de effectiviteit van een hek toe kan nemen door het vastmaken van nieuwe objecten aan dat hek, omdat dassen vaak hun neus gebruiken om dergelijke objecten te onderzoeken. Schokken aan de gevoelige neus zijn krachtiger dan schokken elders en zullen mogelijk voor een langduriger effect zorgen.

Er is ook onderzocht hoe lang het effect van elektrische omheinding op dassen standhoudt na verwijdering van de omheining. Tolhurst et al. (2008) testten het effect van elektrische lading op de frequentie van dassenbezoeken aan boerderijgebouwen zoals veestallen, bij delen van boerderijen die wel of niet omheind werden. Het ging om een bedrading met 4 parallelle draden op hoogtes van 10, 15, 20 en $30 \mathrm{~cm}$ boven de grond, met een lading van 6-9kV. Elektrische omheining was effectief bij het voorkomen van toegang tot de boerderijgebouwen en verminderde de toegang tot de gebouwen aanzienlijk. Niet alleen nam het gebruik van gebouwen af in omheinde delen, maar ook in de nietomheinde controlegebouwen. Dit suggereert dat de dassen boerderijen waar op delen elektrische hekken zijn geplaatst in hun geheel sterk vermijden. Op de eerste nacht na installatie werden 31 contacten met dassen geregistreerd via cameravallen, wat naar nul zakte op de tweede nacht en na lage frequentie daarna. Er werden geen dassen vastgesteld na de eerste nacht waarop hekken werden verwijderd, wat aangeeft dat het effect voortduurde in afwezigheid van de elektrische omheining. De bezoeken namen daarna wel weer toe vanaf een week na verwijdering, maar met een lagere frequentie dan voor installatie van de hekken. Dit suggereert dat de werking van elektrische omheining ook voortduurt nadat deze buiten werking is gesteld. 


\subsubsection{Ultrasone afweergeluiden}

Ultrasone geluiden zijn voorgesteld als een goed, wijdvoorhanden alternatief voor lethale middelen om zoogdieren te weren van voedselpercelen (Bomford en O'Brien, 1990). Toch lopen de resultaten van de effectiviteit van die middelen uiteen. Ward et al. (2008) testten het effect van een ultrasonisch apparaat op dassen en vergeleken het met een waterspuitapparaat. Het ultrasone apparaat, of het nu alleen of in combinatie met de waterspuit werd gebruikt, leidde tot een aanzienlijk hogere dassenactiviteit in vergelijking met controleplots en het gebruik van lokvoer door dassen was ook hoger wanneer het ultrasone apparaat alleen werd gebruikt. Als alleen een waterstraal werd gebruikt, ging het gebruik van lokmiddelen achteruit in vergelijking met de controleplots, maar het verschil tussen de behandelde percelen en controlepercelen was gemiddeld slechts $12 \%$. De auteurs concluderen dat geen van beide apparaten, alleen of in combinatie, een effectieve oplossing biedt voor het weren van dassen; het voordeel van een rijk voedselaanbod weegt blijkbaar vaak op tegen de kosten die dassen ondervinden van dergelijke afweerapparaten.

De ultrasone geluiden zijn zeer waarschijnlijk niet effectief om verschillende redenen. Ten eerste zijn bij een slechte voedselsituatie dassen minder geneigd om uit te wijken, omdat de kosten niet opwegen tegen de baten (voorbeeld bij bruine ratten Rattus norvegicus: Shumake et al., 1982). Ook kan het geluid niet hard genoeg zijn (bijv. minder dan $130 \mathrm{db}$ ), waardoor het apparaat een aantrekkende werking i.p.v. een aanlokkende werking krijgt, en gewenning aan geluiden kan optreden, zeker wanneer die voortdurend worden gespeeld (wederom bij bruine ratten: Lavoie en Glahn, 1977; Shumake et al., 1982). Op het moment dat dassen gewend zijn of zelfs aangetrokken worden tot een stimulus kan het inzetten van een nieuwe, negatieve stimulus mogelijk echter weer wel het beoogde effect bereiken. Hiervoor is nog meer onderzoek nodig.

\subsubsection{Habitatbeheer}

Dassen foerageren seizoensgebonden op larven van langpootmuggen (emelten) en keverlarven (engerlingen) (Hollander, 2016). In graszoden veroorzaken deze insecten schade. Dassen foerageren op deze insecten door de graszode te ontwortelen en op te tillen (Faunaschade Preventie Kit. Module das., 2016). Daarnaast foerageren dassen op regenwormen. Door de abundantie van regenwormen, engerlingen en emelten te verminderen, wordt grasland minder aantrekkelijk voor dassen. Door in de nazomer de bodem te verdichten of chemische of biologische bestrijding (parasitaire nematoden; larven verwijderen door ze naar de oppervlakte te laten komen door besproeiing of door gras te bedekken met plastic) toe te passen, kan dit worden bereikt. De methode is effectief (Ward et al., 2008). Onduidelijk is wat eventuele negatieve effecten zijn van regenwormbestrijding op de bodemstructuur en productiviteit van het gewas (Spurgeon et al., 2013).

Schade zou ook kunnen worden voorkomen door het telen van alternatieve gewassen die minder aantrekkelijk zijn voor dassen of minder oogstresten opleveren. Bij opvolgende gewassen dient gewacht te worden tot de resten van het vorige gewas zijn verdwenen (Faunaschade Preventie Kit. Module das., 2016). Niet onderzocht is in hoeverre met alternatieve gewassen, rassen en teeltwijzen schade is te voorkomen (Hollander, 2016).

\subsubsection{Afleidend voeren}

Dassen zouden kunnen worden gestuurd in hun foerageergedrag door afleidend te voeren. Afleidend voeren is gericht op het verminderen van schade aan (kapitaalintensieve) gewassen. Dit kan door het aanbieden van blijvend grasland met een hoge dichtheid aan regenwormen of door bijvoeren met bv. fruit en noten. Nadeel zou kunnen zijn dat de draagkracht wordt verhoogd waardoor de populatie sneller groeit, met als gevolg meer schade. $\mathrm{Er}$ is onvoldoende wetenschappelijk onderzoek gedaan naar de effecten van afleidend voeren ter voorkoming van dassenschade (Hollander, 2016).

\subsubsection{Conclusie}

De aan dassen toegekende schade valt in het niet bij totale landbouwopbrengsten en in vergelijking met andere soorten die verantwoordelijk worden gehouden voor landbouwschade. Toch kunnen dassen voor aanzienlijke lokale schade zorgen in gewassen, die kunnen worden verminderd door het verplaatsen van dassen, chemische afweermiddelen en door schrikdraad rond percelen met kwetsbare gewassen. 
Verjaagmiddelen dassen in het kort (bron: Buij et al., 2016)

\begin{tabular}{|c|c|c|c|}
\hline Middel & Effectiviteit* & Kosten & Toelichting \\
\hline $\begin{array}{l}\text { Verplaatsen dassen } \\
\text { Ontoegankelijk maken burcht } \\
\text { Translocatie }\end{array}$ & $-->+++$ & --- & $\begin{array}{l}\text { Effectief, alleen als er sprake is van een langeafstand- } \\
\text { translocatie naar gunstig gebied zonder dassen, waarvoor } \\
\text { hoge kosten kunnen gelden. }\end{array}$ \\
\hline Chemische afweermiddelen & $0->++$ & $+->---$ & $\begin{array}{l}\text { Potentieel effectief, maar nog relatief weinig getest en } \\
\text { arbeidsintensief. }\end{array}$ \\
\hline $\begin{array}{l}\text { Fysieke barrières } \\
\text { Schrikdraad } \\
\text { Waterspuit }\end{array}$ & $\begin{array}{l}++ \\
---\end{array}$ & --- & $\begin{array}{l}\text { Schrikdraad effectief, zelfs (deels) na verwijdering. Wel } \\
\text { afhankelijk van ontwerp van het hek en spanning. Relatief } \\
\text { duur, weinig empirisch onderzocht. } \\
\text { Waterspuit is niet effectief. }\end{array}$ \\
\hline $\begin{array}{l}\text { Akoestische verjaagmethoden } \\
\text { Ultrasoon geluid }\end{array}$ & - & - & Nauwelijks tot geen effect. \\
\hline $\begin{array}{l}\text { Habitatbeheer } \\
\text { Bestrijding ongewervelden } \\
\text { Alternatieve gewassen }\end{array}$ & $+?$ & $+->-$ & $\begin{array}{l}\text { In potentie een kostenefficiënte methode, maar niet } \\
\text { empirisch onderzocht. }\end{array}$ \\
\hline Afleidend voeren & $+?$ & +++ & $\begin{array}{l}\text { In potentie een kostenefficiënte en duurzame methode, maar } \\
\text { niet empirisch onderzocht. }\end{array}$ \\
\hline
\end{tabular}

\section{Aanbevelingen voor aanvullend onderzoek}

- Onderzoek naar de effectiviteit van translocatie en ongeschikt maken van het gebied zodat hervestiging uitblijft.

- Onderzoek naar chemische afweermiddelen.

- Onderzoek naar het effect van de bestrijding van ongewervelden en de teelt van alternatieve gewassen.

- Onderzoek naar afleidend voeren. 


\section{Edelhert}

\section{AANTALSONTWIKKELING}

Ontwikkeling als schadesoort

Sinds 2000 is er sprake van een stijgende trend van de uitgekeerde schade die werd toegeschreven aan edelherten (Fig. 6). Het piekjaar was 2015, toen er ca. $€ 340.000$ werd uitgekeerd aan hertenschade. In 2016 was de uitgekeerde schade maar de helft van de schade in 2015. In uitgekeerde schadebedragen zijn herten vergelijkbaar met dassen. Met $€ 1,5 \mathrm{mln}$ toegekeerde schade sinds 2000 zijn herten verantwoordelijk voor 1,2\% van de totale toegekeerde schade aan de top 10-schadesoorten.

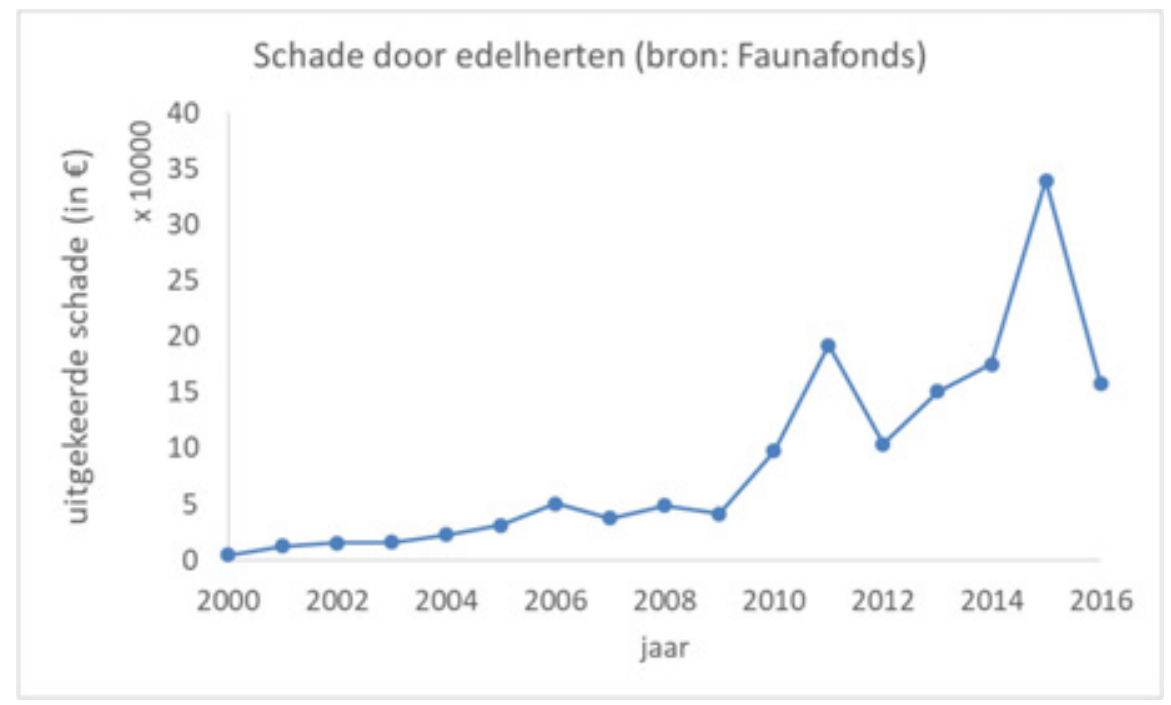

Figuur 6 Bedrag (in $€$ ) uitgekeerd voor schade toegekend aan edelherten gedurende 2000-2016.

Positieve effecten voor de landbouw

Het edelhert heeft geen positieve effecten voor de landbouw.

\subsection{Belangrijkste werings- of verjagingsmiddelen}

Edelherten veroorzaken aanzienlijke conflicten in de landbouw. Er zijn meerdere niet-dodelijke opties die de populatiedynamiek van edelherten direct kunnen beïnvloeden (bijv. vruchtbaarheidssturing, translocatie), die zorgen voor bescherming van gewassen tegen schade (bijv. hekken, afweermiddelen) of door middel van verjaging (door herdershonden of mensen). Er kunnen ook, net als bij wilde zwijnen, alternatieve voedselgebieden worden aangelegd die herten weglokken van gevoelige gewassen.

\subsubsection{Afleidend voeren}

Met afleidend voeren door de aanleg van wildweides, of percelen met 'offergewassen', binnen natuurgebieden kunnen edelherten worden weggelokt van schadegevoelige percelen. De effectiviteit is wisselend. Sommige studies tonen een vermindering van de schade aan, terwijl bij andere studies de schade toeneemt (Putman en Staines, 2004; Hollander, 2016).

\subsubsection{Anticonceptie}

Anticonceptie is een middel om populaties van edelherten te verlagen met als doel om de schade te verminderen. Het omvat verschillende methoden die de voortplanting bij herten kunnen verminderen, waaronder hormonen, hormoonagonisten en immunocontraceptie (Bradford en Hobbs, 2008; Killian et al., 2009; Lammertsma en Jansman, 2016), intra-uteriene apparaten (Malcolm et al., 2010) en chirurgische procedures (MacLean et al., 2006). Anticonceptiemiddelen voor vrijlevende hoefdieren 
kunnen worden gebruikt waar lethale methoden niet doeltreffend of onaanvaardbaar zijn (DeNicola et al., 2000; Malcolm et al., 2010). Over het algemeen is de toepassing van anticonceptiva logistiek en financieel niet haalbaar (Walter et al., 2002), met name in gebieden met grote en toenemende aantallen dieren, waardoor vruchtbaarheidscontrole momenteel geen praktische strategie voor het beheer van schade door herten lijkt (DeNicola et al., 2000; Lammertsma en Jansman, 2016; Kuiper en Van Wieren, 2010). In de praktijk is nog veel onderzoek nodig om tot een rendabele methode te komen die praktisch uitvoerbaar is en het juiste effect heeft zonder ongewenste bijeffecten. Verdere ontwikkeling in anticonceptietechnologie kan resulteren in meer kosteneffectieve anticonceptiva om zo schade te verminderen.

\subsubsection{Omheiningen}

Rasters bieden een effectieve en duurzame, niet-dodelijke techniek om schade door herten te minimaliseren. In de meeste landbouwenclaves binnen natuurgebieden worden kwetsbare teelten (vooral aardappels en bieten) uitgerasterd (Groot Bruinderink et al., 2005). Uitrasteren gebeurt permanent in akkerbouwgebied of bij wisselende percelen in een weidegebied met tijdelijke, elektrische rasters. De effectiviteit van omheiningen kan echter variëren met de kwaliteit van het raster en varieert door de seizoenen (Bauman et al., 1999). De motivatie van herten om een omheining te passeren, wordt waarschijnlijk beïnvloed door factoren als de bronst en verstoring door jachtactiviteiten. De kwaliteit van een raster wordt vooral bepaald door de constructie en hoogte (minimaal 2 m hoog; Faunaschade Preventie Kit. Module hertachtigen, 2016).

Er zijn verschillende typen omheiningen om herten te weren uit gewassen. Omheiningen bieden bescherming voor gewassen op een van de volgende manieren: (1) als een fysieke barrière, (2) als een psychologische barrière of (3) als een combinatie van beide. Goddard et al., (2001) testten een verscheidenheid aan hekken en vonden dat een 1,9 m geweven hek volledig effectief was bij het beperken van bewegingen van herten, terwijl een hek gemaakt van 0,8 m weefdraadnetwerk een klein percentage testdieren doorliet. Een typisch 2,4-m hoog geweven draadhek is een fysieke barrière voor herten en vermindert de kans dat een dier erover, onder of doorheen gaat. Tegelijkertijd kunnen enkelof dubbelstrengs elektrische hekken fungeren als psychologische belemmering op basis van vermijdingsconditionering (McKillop en Sibly, 1988). Dit treedt op wanneer een dier contact maakt met het hek, vaak met de neus of de tong, en een krachtige elektrische schok krijgt. Hoewel dergelijke omheiningen potentieel schade sterk kunnen elimineren, zijn ze niet altijd kostenefficiënt, vooral in situaties waar de waarde van het gewas laag is en het te beschermen gebied groot (VerCauteren et al., 2006).

Over het algemeen zijn de zwakste punten in hekken de poorten, die gesloten moeten zijn om hekken effectief te maken. Automatisch sluiten van poorten is geëvalueerd met gemengde resultaten (bijv. Seamans en Helon, 2008; VerCauteren et al., 2009).

\subsubsection{Akoestische en visuele afweermiddelen}

Er zijn maar beperkte onderzoeksresultaten gepubliceerd met betrekking tot de werkzaamheid van akoestische en visuele schrikmiddelen voor herten (VerCauteren et al., 2005). De effectiefste technieken richten zich op meerdere zintuigen tegelijk (Nolte, 1999). Schrikapparatuur bootst eigenschappen van roofdieren na (bijvoorbeeld geluid of verschijning) gericht op specifieke zintuigen van herten. Over het algemeen zijn dergelijke afschrikmiddelen niet effectief gedurende langere tijd (Bomford en O'Brien, 1990; Koehler et al., 1990), hoewel ze nuttig kunnen zijn om schade tijdelijk (bijv. tijdens een belangrijke periode van het jaar) te verlagen (Nolte, 1999). Wanneer dergelijke technieken niet worden ondersteund door negatieve fysieke stimuli (zoals een schok of lichamelijk contact), volgt vaak gewenning (Nolte, 1999).

Propaankanonnen en andere sonische apparaten kunnen tijdelijk de schade door herten verminderen, maar zijn in het algemeen weinig of niet doeltreffend, ook niet voor kortere perioden (Koehler et al., 1990; Belant et al., 1998; Gilsdorf et al., 2004). Hun effectiviteit kan worden verbeterd door tegelijkertijd een verscheidenheid aan andere negatieve stimuli te gebruiken (Nolte, 1999; Beringer et al., 2003). Apparaten die worden geactiveerd ongeacht de aanwezigheid van herten zijn minder effectief dan die apparaten die alleen in aanwezigheid van herten geactiveerd worden (Gilsdorf et al., 2004). Rode lasers waren niet effectief om schade door herten te verminderen, omdat herten 
waarschijnlijk geen rode kleuren kunnen zien (bereik van 630-650 nm; VerCauteren en Pipas, 2003).

Zelfs wanneer ze 's nachts met laserlichten in hun gezichtsveld (450-537 nm, blauwgroen)

geconfronteerd werden, vluchtten ze niet (VerCauteren et al., 2006).

Beringer et al. (2003) ontwikkelden en evalueerden een apparaat met akoestische en visuele stimuli die witstaartherten verjoegen van sojabonen. Ze maakten gebruik van geluid van agressieve honden, schoten, noodroepen e.d. De auteurs concluderen dat een automatisch geactiveerde verschrikker alleen op de korte termijn voor een oplossing zorgt. Een soortgelijk automatisch geactiveerd, akoestisch apparaat was onvoldoende bij het beschermen van mais tegen herten (Gilsdorf et al., 2004). Nolte (1999) stelde voor dat aanvulling op pyrotechnisch gebruik (d.w.z. door een auditieve prikkel) met een incidentele impact door een rubberen kogel een effectieve negatieve stimulus zou kunnen verschaffen.

\subsubsection{Chemische afweer}

Chemische afweermiddelen zijn niet-dodelijke chemicaliën die theoretisch de smaak van een plant verminderen, of het gevoelde risico op predatie verhogen, en derhalve schade door vraat kunnen doen verminderen. Er zijn meerdere studies gedaan naar de effectiviteit van geurstoffen om schade door herten te verminderen (Harris et al., 1983; Palmer et al., 1983; Conover, 1984). Actieve ingrediënten van geurafstotende stoffen bevatten gewoonlijk ammoniumzepen (Hygnstrom en Craven, 1988; Andelt et al., 1994), rotte-eierlucht (Swihart en Conover, 1990; Andelt et al., 1991), roofdierengeur (Swihart et al., 1991; Seamans et al., 2002) en menselijke voedingsmiddelen (Andelt et al., 1994). Deze afweermiddelen verlagen de smakelijkheid van planten of veroorzaken negatieve gevolgen voor het consumerende dier waardoor aversieve conditionering optreedt. Schade aan gewassen door herten kan worden voorkomen door contactafstotende middelen die capsaïcine bevatten, die een 'hete' sensatie veroorzaakt bij contact met slijmvliezen (Andelt et al., 1994; Baker et al., 1999). Bittere middelen (bijvoorbeeld denatoniumbenzoaat, Swihart en Conover, 1990; Andelt et al., 1991) en bepaalde eiwitten (Kimball et al., 2009) verminderen ook de smakelijkheid van gewasplanten.

Veel factoren bepalen de werkzaamheid van afweermiddelen en alle afweermiddelen hebben een beperkte effectiviteit op de lange termijn. Afweermiddelen kunnen afgebroken worden, zodat herhaalde toepassingen noodzakelijk zijn. Terwijl planten blijven groeien, moeten afweermiddelen opnieuw worden toegepast op nieuwe bladeren of scheuten. Ongeacht het gebruik van afweermiddelen, is schade te verwachten bij het gebruik van chemische afweermiddelen, zelfs wanneer de omstandigheden optimaal zijn. Voedselstress speelt een belangrijke rol speelt bij de effectiviteit van dergelijke afweermiddelen (Andelt et al., 1992) en ze zijn niet altijd succesvol (bijv. roofdierengeur; Elmeros et al., 2011). De afweermiddelen zijn het effectiefst wanneer de motivatie (d.w.z. voedselstress) laag is en alternatieve voedingsbronnen beschikbaar zijn. Gezien de beperkingen (duur van werkzaamheid, grootte van het te behandelen gebied) dienen afweermiddelen gebruikt te worden in combinatie met andere methoden (bijv. omheining) voor een zinvol effect.

\subsubsection{Habitatmodificatie}

Door rondom leefgebied van edelherten een bufferzone met een onaantrekkelijke vegetatie aan te leggen, kan mogelijk schade worden voorkomen. Onderzoek wijst uit dat ze zelden ver van dekking biedend (bos)gebied foerageren (Bleier et al., 2017). In Hongarije vond $90 \%$ van de schade plaats binnen $300 \mathrm{~m}$ van de bosrand. Door dekking rondom leefgebieden van edelherten te verwijderen en geen geschikt foerageergebied aan te bieden, kan bij lage dichtheden van edelherten mogelijk schade worden voorkomen. Dit is echter niet wetenschappelijk aangetoond.

\subsubsection{Conclusie}

De aan herten toegekende schade is in vergelijking met andere schadesoorten laag op nationaal niveau. Lokaal optredende schade kan aanzienlijk zijn en het best kan worden voorkomen door het plaatsen van schrikdraad rond percelen met kwetsbare, schadegevoelige gewassen. 
Verjaagmiddelen edelherten in het kort (bron: Buij et al., 2016)

\begin{tabular}{|c|c|c|c|}
\hline Middel & Effectiviteit* & Kosten & Toelichting \\
\hline Vruchtbaarheidssturing & $+->---$ & --- & $\begin{array}{l}\text { Momenteel geen praktische strategie voor het beheer van } \\
\text { schade door herten. Effectiviteit afhankelijk van de grootte } \\
\text { van het gebied. Duur bij hoge aantallen herten. Weinig } \\
\text { empirisch onderzocht. }\end{array}$ \\
\hline Afleidend voeren & $+->---$ & +++ & $\begin{array}{l}\text { Alleen in specifieke situaties. Variabele resultaten, alleen } \\
\text { succesvol indien voldoende ver uit de buurt van } \\
\text { landbouwgrond. }\end{array}$ \\
\hline $\begin{array}{l}\text { Fysieke barrières } \\
\text { Omheiningen }\end{array}$ & +++ & --- & $\begin{array}{l}\text { Over het algemeen en afhankelijk van het type hek een } \\
\text { effectief middel om schade te verlagen, niet altijd } \\
\text { kostenefficiënt. }\end{array}$ \\
\hline $\begin{array}{l}\text { Akoestische en visuele } \\
\text { afweermiddelen }\end{array}$ & $+->---$ & ++ & $\begin{array}{l}\text { De effectiefste technieken richten zich op meerdere zintuigen } \\
\text { tegelijk, maar niet effectief gedurende langere tijd. } \\
\text { Afweermiddelen die worden geactiveerd ongeacht de } \\
\text { aanwezigheid van herten zijn minder effectief dan die } \\
\text { apparaten die alleen in aanwezigheid van herten geactiveerd } \\
\text { worden. }\end{array}$ \\
\hline Chemische afweermiddelen & $+->---$ & $-->---$ & $\begin{array}{l}\text { Variabele werkzaamheid, beperkingen voor duur van } \\
\text { werkzaamheid, grootte van het te behandelen gebied. Ze } \\
\text { dienen gebruikt te worden in combinatie met andere } \\
\text { methoden (bijv. omheining) voor een zinvol effect. }\end{array}$ \\
\hline $\begin{array}{l}\text { Habitatbeheer } \\
\text { Bufferzone }\end{array}$ & $+?$ & $+->---$ & $\begin{array}{l}\text { In potentie een kostenefficiënte methode afhankelijk van de } \\
\text { ruimtelijke configuratie van een leefgebied, maar niet } \\
\text { empirisch onderzocht. }\end{array}$ \\
\hline
\end{tabular}

\subsubsection{Aanbevelingen voor aanvullend onderzoek}

- De effectiefste verjagende verjagingsmiddelen spelen tegelijkertijd in op meerdere zintuigen, waaronder aanraking, zodat toekomstig onderzoek zich vooral daar op zou moeten richten. 


\section{Wild zwijn}

\section{AANTALSONTWIKKELING}

Ontwikkeling als schadesoort

Sinds 2000 is er sprake van een stijgende trend van de uitgekeerde schade die werd toegeschreven aan zwijnen (Fig. 5). Het piekjaar was 2010, toen er ca. $€ 211.000$ werd uitgekeerd aan zwijnenschade. Sinds 2014 is er weer sprake van een toename van de uitgekeerde schade na een afname van de schade sinds 2010. Verhoudingsgewijs waren zwijnen met maar $€ 1,2 \mathrm{mln}$ toegekeerde schade sinds 2000 verantwoordelijk voor maar $1 \%$ van de totale toegekeerde schade aan de top 10-schadesoorten.

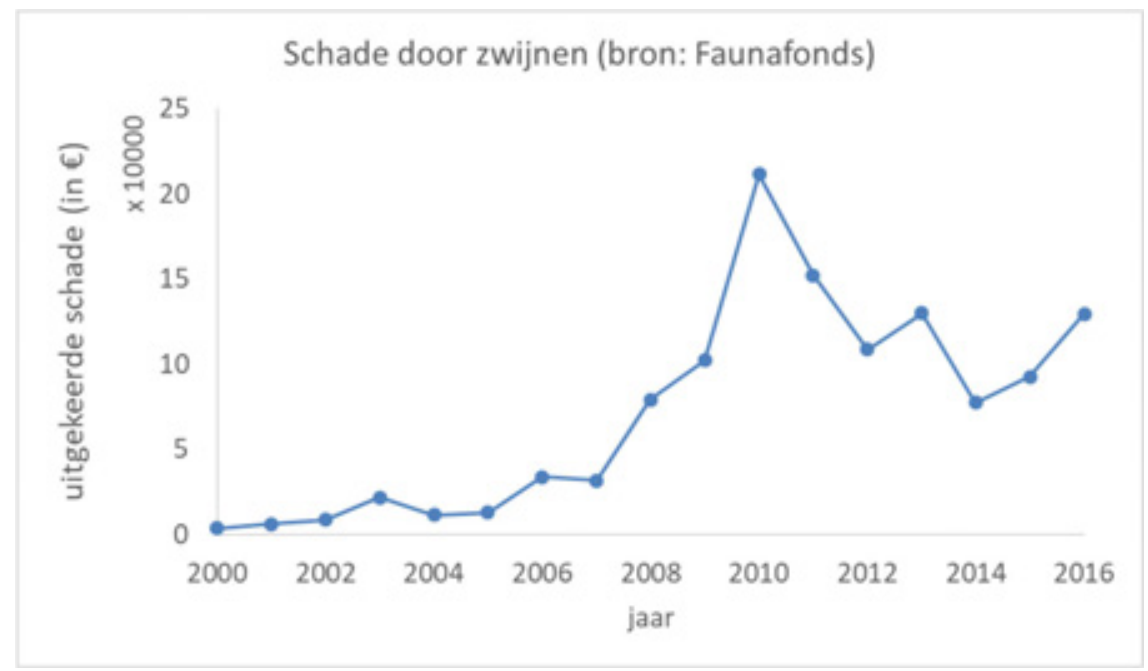

Figuur 5 Bedrag (in €) uitgekeerd voor schade toegekend aan zwijnen gedurende 2000-2016.

Positieve effecten voor de landbouw

Wilde zwijnen hebben geen positieve effecten voor de landbouw.

\subsection{Belangrijkste werings- of verjagingsmiddelen}

Oord (2002, 2009) en Guldemond et al. (2015) geven een overzicht van preventieve maatregelen per gewas voor wild zwijn, maar bevat geen onderzoeksresultaten naar de effectiviteit. Hier ligt daarom de nadruk op resultaten uit buitenlands onderzoek. De volgende niet-lethale methoden zijn gebruikt om de schade door wilde zwijnen zo veel mogelijk te reduceren (Briedermann, 1990): (1) bijvoeren in bossen om dieren weg te lokken van landbouwgebied, en (2) het bouwen van (schrikdraad)hekken rond landbouwgewassen. Methoden op basis van akoestische en optische afschrikking hebben geen betrouwbare langetermijnresultaten behaald (Vassant et al., 1992; Remijnse en Van Bommel, 2010; Bobek et al., 2017) en laten we hier grotendeels buiten beschouwing. Deze methoden betreffen o.a. radio's, PIR-geactiveerde hoornen, gaskanonnen, Bernatex collageenbanden en zonne-energie ledblinkers.

\subsubsection{Afleidend voeren}

Met afleidend voeren door de aanleg van wildweides of percelen met 'offergewassen' met bv. mais, binnen natuurgebieden, kunnen zwijnen worden weggelokt van schadegevoelige percelen. Terwijl sommige studies een positief effect laten zien van het verstrekken van alternatief voedsel op het verminderen van schade door zwijnen (Andrzejewski en Jezierski, 1978; Vassant, 1994), laten andere studies geen of zelfs een negatief effect zien (Hahn en Eisfeld, 1998; Geisser en Reyer, 2004). De effectiviteit van het bijvoeren van zwijnen (wat strikt verboden is in Nederland) voor schadevermindering is zeer controversieel en lijkt te berusten op verschillende aspecten. Hoewel sommige studies bewijs leveren voor het succes van de methode bij het verminderen van wilde 
zwijnenschade op landbouwgewassen (Vassant et al., 1992; Vassant, 1994; Calenge et al., 2004), zijn er ook studies die negatieve effecten melden (Hahn en Eisfeld, 1998; Cellina, 2008). In sommige gevallen kan dat komen door de hoge dichtheid van bijvoerstations, waardoor zwijnen aangetrokken worden tot bosdelen die grenzen aan landbouwland. Zeker in gefragmenteerde bossen zullen veel voederstations in de buurt van landbouwland liggen, waardoor toch schade optreedt. De dichtheid en precieze locatie van wildweides dient om die reden goed overwogen te worden. Extra voedsel verbetert bovendien de overleving onder ongunstige omstandigheden, verhoogt de reproductie en versnelt het begin van de voortplanting, hetgeen tot een toename van het aantal zwijnen en schade kan leiden (Andrzejewski en Jezierski, 1978; Briedermann, 1990; Bieber en Ruf, 2005; Groot Bruinderink et al., 2009). Onderzoek door Schley et al. (2008) over een periode van tien jaar in Luxemburg wees uit dat de methode slechts in zeldzame gevallen effectief kan zijn. In de studies die een succesvolle vermindering van schade door middel van bijvoeren hebben vastgesteld, werd dat voedsel op een afstand van ten minste $1 \mathrm{~km}$ van de bosrand verstrekt, het verstrekte voedsel werd over grote gebieden verspreid en pas tijdens de kritieke periode. Daarnaast dient de dichtheid aan wilde zwijnen laag te zijn.

\subsubsection{Elektrische hekken}

Elektrische omheiningen worden beschouwd als een van de succesvolste methodes van schadepreventie (bijv. Baettig, 1988; Breton, 1994; Vassant, 1994; Fernandez, 2012), hoewel veel van die studies beperkt waren tot kleine gebieden of gericht op omheiningen rond mais, tarwe of aardappelen. Elektrische hekken kunnen op een effectieve manier kleine gebieden beschermen tegen zwijnen. Er is echter niet onderzocht hoe de omheining de schade aantast in aangrenzende gebieden of in minder beschermde culturen zoals grasland (Bobek et al., 2017). In mastarme jaren (voedseltekort) neemt de druk toe op omrasterde gebieden en proberen zwijnen vaker om een omheining te passeren; ze slagen hier dan ook vaker in (Groot Bruinderink et al., 2009). Geisser en Reyer (2004) vonden bij hun analyse van relaties tussen aantallen zwijnen en omheiningen geen aanwijzingen voor een afname van de schadefrequentie door zwijnen met toenemende omheining. Integendeel, ze vonden een zeer significante positieve relatie tussen zwijnen en omheining, in ruimte en tijd. De aannemelijkste verklaring voor deze positieve relatie tussen omheining-lengte en schade is dat de uitbreiding van de omheining de reactie van boeren op de toenemende schade weerspiegelt. Met andere woorden, de wilde zwijnen beïnvloeden menselijke activiteiten in plaats van dat de mensen de zwijnen kunnen controleren.

\subsubsection{Geur afschrikmiddel}

Naast bijvoeren en omheiningen kan schade door wilde zwijnen ook worden verminderd door gebruik van afschrikwekkende geuren. Wilde zwijnen gebruiken hun goede reukvermogen voor oriëntatie en foerageren, maar ook voor intraspecifieke sociale interacties en voor het vermijden van natuurlijke vijanden (Schlageter en Haag-Wackernagel, 2012). Het reukvermogen van wilde zwijnen is erg goed ontwikkeld (Gunterschulze, 1979) en daarom kunnen geurafstotende middelen een veelbelovende manier zijn om wilde zwijnen uit landbouwgewassen af te schrikken.

Er zijn diverse goedkope geurafschrikmiddelen in de handel verkrijgbaar. De meeste hiervan hebben echter geen wetenschappelijk bewezen werkzaamheid (Groot Bruinderink, 2008). Volgens Groot Bruinderink zou mogelijk ADAC-Hagopur Duftzaun werkzaam kunnen zijn, hiernaar zou nader onderzoek moeten worden gedaan. Schlageter en Haag-Wackernagel (2012) onderzochten de effectiviteit van het geurafstotende 'Wildschwein-Stopp' tegen wilde zwijnen. Ze voerden veldexperimenten uit met wilde zwijnen op lokvoer in Zwitserland. De geurafstotende stof was niet in staat om te voorkomen dat de wilde zwijnen aangetrokken werden tot het lokvoer, met een afschrikkende werking van $0,4 \%$ ten opzichte van onbehandeld lokvoer. Deze resultaten suggereren dat het geurafweermiddel ondoeltreffend was en daarom niet aan te bevelen voor gewasbescherming. Op basis van hun studie twijfelen de auteurs aan de werking van angst-inducerende afstotende geurstoffen om vraat door wilde zwijnen tegen te gaan, vooral in gebieden waar natuurlijke vijanden zoals wolf, bruine beer of lynx afwezig of zeer zeldzaam zijn. 


\subsubsection{Habitatmodificatie}

Door rondom leefgebied van wilde zwijnen een bufferzone met onaantrekkelijke vegetatie aan te leggen, kan mogelijk schade worden voorkomen. Onderzoek wijst uit dat wilde zwijnen zelden ver van dekking biedend (bos)gebied foerageren (Schley et al., 2008; Bleier et al., 2017). In Hongarije vond $90 \%$ van de schade plaats binnen $300 \mathrm{~m}$ van de bosrand (Bleier et al., 2017). Door dekking rondom leefgebieden van wilde zwijnen te verwijderen en geen geschikt foerageergebied aan te bieden, kan bij lage dichtheden van wilde zwijnen mogelijk schade worden voorkomen.

\subsubsection{Conclusie}

De aan zwijnen toegekende schade is over het algemeen laag, hoewel lokaal hoge schade het best kan worden voorkomen door het plaatsen van schrikdraad rond percelen met kwetsbare gewassen.

\begin{tabular}{|c|c|c|c|}
\hline Middel & Effectiviteit* & Kosten & Toelichting \\
\hline Afleidend voeren & $+->---$ & +++ & $\begin{array}{l}\text { Alleen in specifieke situaties. Variabele resultaten, alleen } \\
\text { succesvol indien voldoende ver uit de buurt van } \\
\text { landbouwgrond. }\end{array}$ \\
\hline $\begin{array}{l}\text { Fysieke barrières } \\
\text { Schrikdraad }\end{array}$ & +++ & --- & $\begin{array}{l}\text { Effectief middel om kleine gebieden en specifieke gewassen. } \\
\text { Op grotere schaal is niet bekend welk effect omheiningen } \\
\text { hebben op schade. }\end{array}$ \\
\hline $\begin{array}{l}\text { Chemische afweermiddelen } \\
\text { Geurafschrikmiddel }\end{array}$ & --- & $-->---$ & Geen wetenschappelijk bewezen werkzaamheid. \\
\hline $\begin{array}{l}\text { Habitatbeheer } \\
\text { Bufferzone }\end{array}$ & $+?$ & $+->---$ & $\begin{array}{l}\text { In potentie een kostenefficiënte methode afhankelijk van de } \\
\text { ruimtelijke configuratie van een leefgebied, maar niet } \\
\text { empirisch onderzocht. }\end{array}$ \\
\hline
\end{tabular}

\section{Aanbevelingen voor aanvullend onderzoek}

- Vooral naar de werkzaamheid van chemische afweermiddelen is meer onderzoek wenselijk. 


\section{AANTALSONTWIKKELING (BRON: SOVON, 2017)}

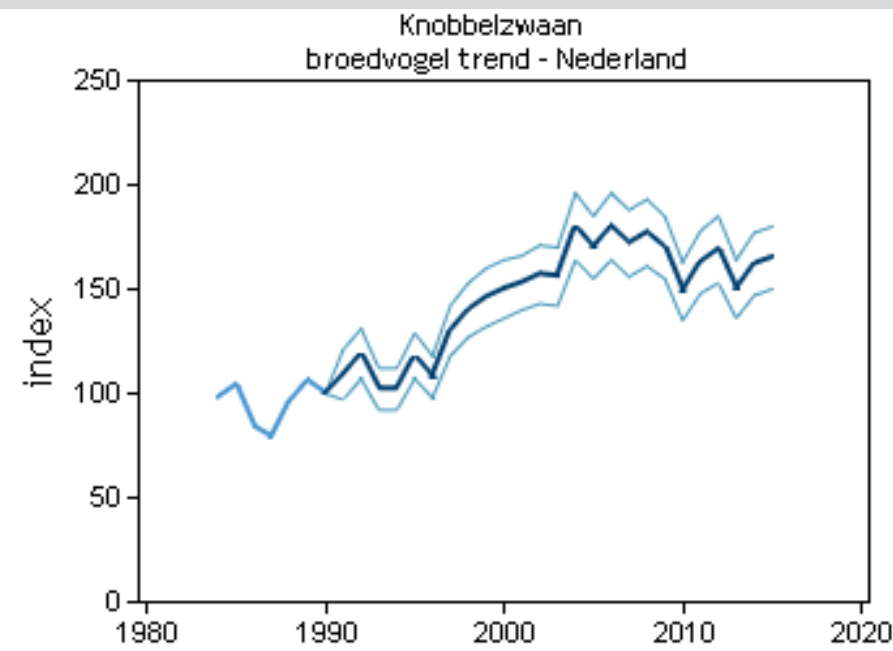

(9) Netwerk Ecologische Wonitoring (Sovon, CBS)

De broedvogeltrend is gebaseerd op het Meetnet Broedvogels (BMP). Weergegeven is de jaarlijkse index van de broedpopulatie t.o.v. 1990 en de standaardfout.

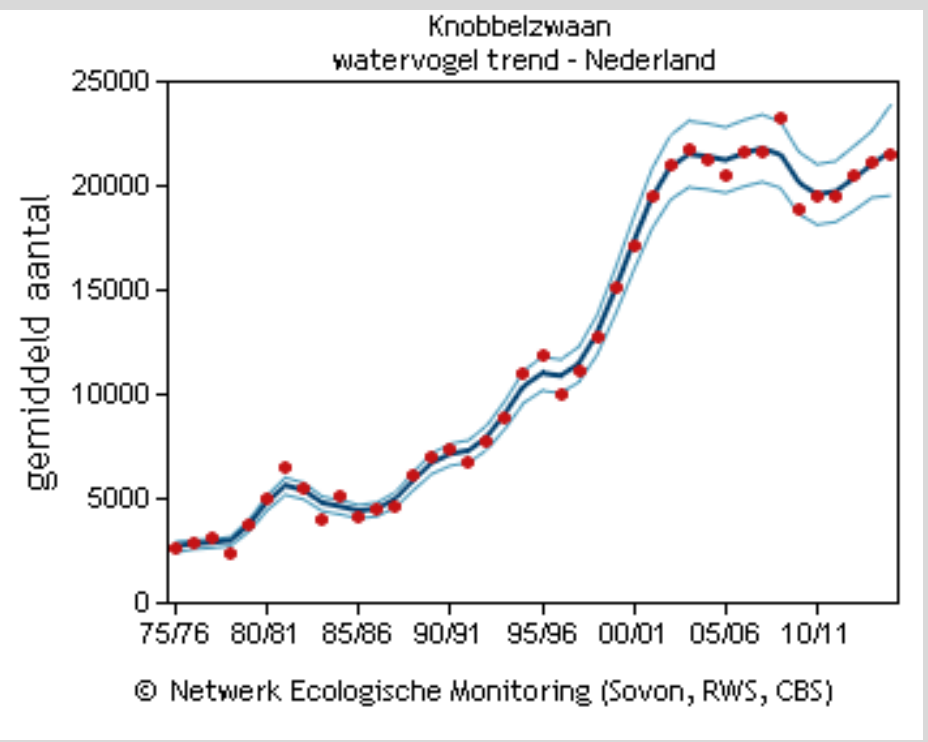

De watervogeltrend is gebaseerd op het Meetnet Watervogels (seizoen juli $t / m$ juni). Weergegeven is het seizoensgemiddelde (rode punten), de trendlijn (donkergekleurde lijn) en het $95 \%$ betrouwbaarheidsinterval van de trendlijn (lichtgekleurde lijn).

\section{Broedtijd}

De meeste knobbelzwanen broeden in de laaggelegen delen van het land, vooral in open graslanden met veel sloten in het veenweidegebied. Rond meren en plassen treden soms concentraties op. Veel knobbelzwanen zijn nazaten van om hun dons gekweekte vogels. De laatste van zulke 'zwanendriften' werden rond 1965 opgedoekt. Losgelaten vogels en hun nazaten vormden een groeiende en zich uitbreidende broedpopulatie. Intensieve vervolging remt deze ontwikkeling regionaal af. De broedpopulatie wordt ook gereguleerd door koude winters die zowel wintersterfte veroorzaken als slechte broedprestaties, door verzwakte conditie van broedvogels. 


\section{Buiten broedtijd}

Om de vleugelrui veilig door te brengen, zoeken knobbelzwanen grote, open wateren op. Op de Randmeren, in het IJsselmeergebied en Deltagebied ruien in de zomer duizenden exemplaren, waaronder ook vogels uit het westen van Duitsland. In de herfst zoeken grote aantallen de Randmeren op om te profiteren van de gunstige voedselsituatie met veel waterplanten. In het winterhalfjaar zijn veel knobbelzwanen te vinden in open graslandgebieden in Laag-Nederland. Koud winterweer leidt tot enige verplaatsingen, meestal binnen Nederland, maar soms tot in Frankrijk. Tegelijk kan dan een influx van oostelijke vogels optreden. In het late voorjaar vormen zich plaatselijk groepen onvolwassen vogels, die vervolgens in mei-juni naar de ruigebieden vertrekken. De landelijke aantallen namen lange tijd toe in het voetspoor van de toenemende eigen broedpopulatie. Sinds 2000 stabiliseren de aantallen of nemen ze licht af. Hartje winter verblijven er minstens 40.000 knobbelzwanen in ons land.

\section{Ontwikkeling als schadesoort}

Sinds 2000 is er sprake van een dalende trend van de uitgekeerde schade die werd toegeschreven aan knobbelzwanen (Fig. 7). De uitgekeerde schade in 2016 was ca. $€ 30.000$, circa $20 \%$ van de schade in het piekjaar 2001, toen er nog ca. $€ 146.000$ werd uitgekeerd aan zwanenschade. De door deze soort veroorzaakte schade lijkt daarmee redelijk beheersbaar te zijn geworden. Verhoudingsgewijs waren knobbelzwanen met ca. $€ 1,0 \mathrm{mln}$ toegekeerde schade sinds 2000 verantwoordelijk voor minder dan $1 \%$ van de totale toegekeerde schade aan de top 10 -schadesoorten.

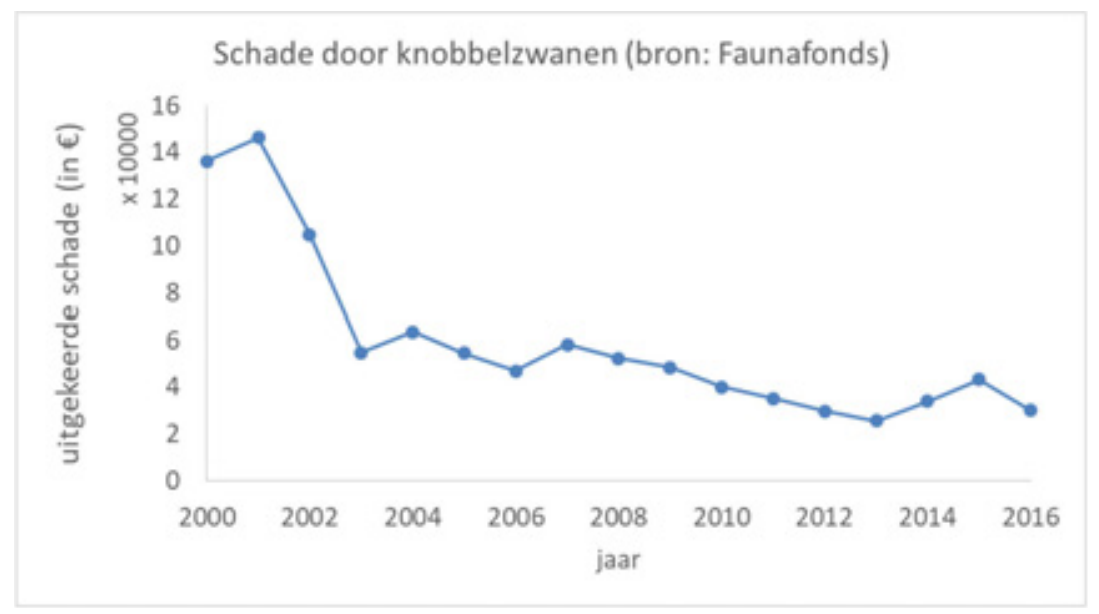

Figuur 7 Bedrag (in $€$ ) uitgekeerd voor schade toegekend aan knobbelzwanen gedurende 20002016.

Positieve effecten voor de landbouw

Theoretisch zou bemesting de gewasgroei kunnen bevorderen. Over het algemeen zal er nauwelijks sprake van een belangrijk effect van bemesting door zwanen (Groot Bruinderink, 1989).

\subsection{Belangrijkste werings- of verjagingsmiddelen}

\subsubsection{Visuele verjaagmethoden}

McKay en Parrott (2002) evalueerden de effectiviteit van visuele verjaagmethoden voor knobbelzwanen die op oliezaad foerageerden, ook in relatie tot chemische afweer, door keutels te tellen op percelen met de volgende middelen: (1) witte vlaggen, (2) waarschuwingstape met touw, en (3) een ziramgebaseerd chemisch afweermiddel op schadegevoelige percelen. Ze vergeleken de behandelde percelen met controlepercelen zonder behandeling. De eerste 8 weken vonden ze aanzienlijke verschillen, die daarna echter wegvielen. De bewijskracht was gering, mede door technische en uitvoeringsproblemen.

In een vervolgexperiment testten Parrot en Watola (2008) het effect van meer duurzame, stevigere tape (zie ook ganzen en smienten). Op alle behandelde percelen nam het aantal keutels na het plaatsen van 
tape significant af (89-100\%), net als de aantallen zwanen (85-100\%). Echter, ook op onbehandelde velden nam het aantal zwanen af, maar minder sterk dan op behandelde percelen. Tapeafweer lijkt zo een zeer effectieve beheersmaatregel voor het verminderen van gewasschade door zwanen. Naast een grote effectiviteit was de tape praktisch en duurzaam (de proeven duurden 14 weken) en werd weinig tapebreuk vastgesteld. Bijbehorende materiaalkosten en arbeidskosten voor het onderhoud waren zeer laag (kosten per hectare varieerde van $£ 29$ tot $£ 52$ ). De gebruikte opstelling maakte de toegang van landbouwvoertuigen langs tape mogelijk en routinewerkzaamheden op de proefpercelen. Toch is in zijn huidige vorm de tape alleen kosteneffectief op de meest begraasde velden.

\subsubsection{Conclusie}

In tegenstelling tot ganzen is er maar weinig onderzoek gedaan naar niet-lethale technieken om schade door knobbelzwanen te voorkomen. Verjaging met tape lijkt (zeer) effectief, als problemen met scheuren van tape en toegankelijkheid tot percelen opgelost kunnen worden.

\begin{tabular}{llll} 
Middel & Effectiviteit & Kosten & $\begin{array}{l}\text { Conclusie } \\
\text { Visuele verjaagmethoden }\end{array}$ \\
& $+/+++$ & $-/++$ & $\begin{array}{l}\text { Tape is effectief, maar logistiek problematisch en mogelijk } \\
\text { alleen kosteneffectief op de meest begraasde velden. }\end{array}$ \\
\hline
\end{tabular}

\subsubsection{Aanbevelingen voor aanvullend onderzoek}

Voor knobbelzwanen is de behoefte aan verbetering of ontwikkeling van verjaagmethoden laag, want de schade is onbelangrijk op nationale schaal en die trend zet door. In de tabel hieronder staan suggesties voor het verder testen van bestaande methoden en de ontwikkeling van nieuwe methoden.

Verjaagmiddelen zwanen in het kort (bron: Buij et al., 2016)

\section{a) Testen van de effectiviteit van bestaande, potentieel geschikte middelen}

- Verfijnen opstellingen voor tape. Om de toepasbaarheid van de tape als beheersmaatregel te maximaliseren, is verder onderzoek nodig om de techniek te verfijnen, zodat het rendabel wordt op velden met minder schade. Alternatieve configuraties van tape, met verminderde dekking per eenheid oppervlak, kunnen getest worden om het optimale evenwicht tussen effectiviteit en kosten te bepalen. Die effectiviteit kan behouden worden bij verminderde tapedekking, zoals de studie van Parrot en Watola (2008) laat zien.

- Akoestische verjaagmethoden of combinaties van visuele en akoestische verjaagmethoden zijn in potentie zeer geschikte methoden, net als bij ganzen, als tenminste kan worden voorkomen dat gewenning optreedt. Met een experimentele opzet kan getest worden welke intensiteit of verjaagfrequentie het effectiefst is bij welk middel (zie bijvoorbeeld Simonsen et al., 2016).

\section{b) Ontwikkeling van nieuwe verjagingsmethoden}

- Systemen die zwanen herkennen met audio en video zodat verjaging daadwerkelijk plaatsvindt wanneer zwanen aanwezig zijn (bijv. Steen et al., 2014) lijken zeer waardevol, zoals bij ganzen. Het testen van dergelijke methoden, in een BACIontwerp en in vergelijking met andere veelgebruikte methoden, lijkt een belangrijke stap voor verdere ontwikkeling.

- Tot op heden is te weinig onderzoek gedaan aan de effectiviteit van de ruimtelijke en temporele samenstelling van alternatieve foerageergebieden bij het weglokken van knobbelzwanen van schadegevoelige percelen. Het gaat dan vooral om gewaskwaliteit, nabijheid van water en openheid van de gebieden. Als ingegrepen wordt in dergelijke landschapseigenschappen en de daarmee samenhangende afweging tussen predatiedruk en voedselkwaliteit, kan foerageren op een manier gestuurd worden die op de langere termijn effect heeft. Toekomstig onderzoek kan zich in dit verband o.a. richten op:

1. De effectiviteit van alternatieve foerageergewassen met snelle hergroei en verhoogd eiwitgehalte om zwanen weg te lokken van gevoelige gewassen. Experimenteel onderzoek met gewassen met verschillende vezelgehalten kunnen worden gebruikt om het potentieel van smaak te beïnvloeden, zodat zwanen weggelokt kunnen worden van schadegevoelige percelen. Hierbij kan worden gedacht aan het ontwikkelen van specifiek 'offergewas' dat op een gegeven moment in de jaarcyclus past bij de behoeften van zwanen in relatie tot gevoelige gewassen die dan ook beschikbaar zijn. Voorbeelden zijn meer eiwitrijke 'lokgewassen' in het voorjaar en de herfst of energierijke voeding in het midden van de winter.

2. Het testen van grassoorten die onaantrekkelijk zijn voor zwanen, maar wel door vee geconsumeerd worden.

3. De relatie tussen de nabijheid van roestgebied en gebiedsopenheid aan de ene kant, zwanenaantallen en schade op gevoelige percelen aan de andere kant en de effectiviteit van maatregelen die hierop ingrijpen. 


\subsection{Leidraad voor beoordeling onderzoek naar schade- reducerende maatregelen}

Ofwel: hoe bepaal je welk onderzoek wanneer zinvol is?

Om te komen tot een optimale inzet van schade-reducerende maatregelen is onderzoek van groot belang. Goed onderbouwde inzichten kunnen helpen een maatschappelijk gedragen evenwicht te vinden tussen natuurbehoudsdoelstellingen en landbouw- of andere vormen van schade. Bij het bepalen wat er onderzocht moet worden, zijn keuzes noodzakelijk. Hoe te komen tot een goede afweging bij het maken van die keuzes?

\section{A. Aan de hand van vraag uit de praktijk}

We beginnen bij een vraag die uit de praktijk van het Faunafonds komt. Als voorbeeld een vraag om een kleinschalig onderzoek naar de effectiviteit van partiële legselbehandeling bij ganzen (zie aanhangsel 1 aan eind van de notitie), hierna aan te duiden als de onderzoeksvraag. De achtergrond van de onderzoeksvraag is dat men een praktische handleiding zou willen hebben waarin staat wat de effectiefste behandelingen zijn (welke behandelingsmethoden, welke fractie van de nesten of eieren te behandelen, welke gebieden etc.) om tot reductie van de populatie en daarmee tot schadevermindering te komen ${ }^{4}$. De vragensteller veronderstelt dat deze kennis er nog niet is en vraagt om eenvoudig, kortlopend, praktijkgericht onderzoek. Hoe hierover tot een standpunt te komen? Hiervoor kan een aantal punten worden langsgelopen.

Vraag 1. Over wat voor type onderzoeksvraag gaat het? Betreft het:

a. Verkennend onderzoek, gericht op het in kaart brengen van de problematiek (is de problematiek substantieel; in welke gebieden speelt het; wat zijn aanknopingspunten voor preventie; is verdiepend onderzoek zinvol?).

b. Dosis-effect of bewijzend onderzoek, gericht op het aantonen van de effectiviteit van schadepreventie maatregelen op bijvoorbeeld a) de omvang van de schade; b) de staat van instandhouding van de schadesoort; c) overige aspecten, zoals dierwelzijn, onbedoelde neveneffecten (andere soorten, milieu).

c. Praktijk/toepassingsonderzoek, gericht op het in praktijk brengen van opgedane kennis over preventie (hoe kan de opgedane kennis in een regeling worden ondergebracht; welke kosten zijn met de uitvoering gemoeid?).

Elke type onderzoek brengt zijn eigen vragen en eisen met zich mee. Deze plaatsbepaling is belangrijk, omdat niet alle betrokkenen vanzelfsprekend hetzelfde beeld van de problematiek voor ogen hebben. Zo zijn er in het ganzendossier bij de betrokkenen uiteenlopende beelden over de effectiviteit van maatregelen: de ene groep is overtuigd van de effectiviteit van een bepaalde maatregel en pleit voor praktijkgericht onderzoek (uitrollen van de methodiek in de praktijk). De andere groep deelt die overtuiging niet en vindt dat eerst meer bewijzend onderzoek nodig is (onderbouwend, bewijzend onderzoek; zie ook aanhangsel 1).

In het geval van de onderzoeksvraag lijkt het erop dat verschillende typen vragen aan de orde zijn. Enerzijds wordt gevraagd om kleinschalig, nieuw uit te voeren veldonderzoek, waarbij de belangrijkste vraag lijkt hoe vervolglegsels het effectiefst voorkomen kunnen worden (= dosis-effectonderzoek). Anderzijds wordt gevraagd om praktische uitvoeringsinstructies (= praktijk/toepassingsonderzoek). Deze twee aspecten dienen uit elkaar te worden gehouden; het opstellen van instructies kan pas aan de orde zijn als er helderheid is over wat de effectiefste behandelmethode is (en er daarover ook consensus bestaat).

\footnotetext{
${ }^{4}$ Dit laatste staat niet expliciet vermeld bij de vraag, die context hebben wij er volledigheidshalve toegevoegd. Dit omdat dat het algemene kader vormt van de onderzoeksinspanningen van het Faunafonds.
} 
Vraag 2. Wat is de bestaande kennis?

Hier gaat het erom een beeld te krijgen van wat er aan literatuur is - in dit geval over de effectiviteit van nestbehandelingen. Hoe de literatuur kan worden beoordeeld op zijn merites, is uitgewerkt in Buij et al. (2016). Voor een volledig overzicht raadpleegt u dat rapport. Hoofdaspecten daarin zijn:

- De ecologisch-wetenschappelijke kwaliteit van het onderzoek - is het goed onderzocht (bewijskracht)?

- De deugdelijkheid (effectiviteit) van het middel - werkt het middel goed, hoe zit het met neveneffecten e.d.?

- De technische uitvoeringsaspecten - is uitvoering duur, zijn er vergunningen nodig?

Het kan zowel om ecologische literatuur gaan als om rapportages uit de uitvoeringspraktijk.

\section{Inzichten uit de literatuur}

De literatuursearch leidt tot een reeks van argumenten voor de wenselijkheid van nieuw onderzoek. Deze argumenten moeten op één lijn worden gebracht ten aanzien van de onderzoeksvraag.

- Een eerste vraag is welke onderzoeken worden meegenomen. Zo blijkt dat er over de wetenschappelijke bewijskracht van onderzoek in veel gevallen kritische opmerkingen te maken zijn. Dat geldt ook voor Nederlands wildschadeonderzoek. Dat hoeft voor gebruik niet altijd een bezwaar te zijn, maar daar weet van hebben is belangrijk. In Buij et al. (2016) worden aanwijzingen gegeven hoe de wetenschappelijke kwaliteit van diverse onderzoeken te beoordelen. Ook is het belangrijk te weten wat de precieze vraag is die in de geraadpleegde literatuur aan de orde is en moet men bepalen of die vraagstelling ook voor het nieuw voorgestelde onderzoek relevant is.

Uit literatuur (Kleijn et al., 2012ab; Baveco et al., 2012):

$\mathrm{Bij}$ legselbehandelingsonderzoek is weleens gekeken naar verschillende behandelingsmethoden, maar is doorgaans een alles-of-niet behandeling toegepast en is niet systematisch gekeken naar het intact laten van bijvoorbeeld 2 eieren.

Twee publicaties t.a.v. nestbehandeling (zie aanhangsel 1) laten zien dat:

Legselbehandelingsonderzoek op Texel:

- Nestbehandeling op zichzelf wel een effect heeft;

- Tekortschiet om de omvang van de populatie te doen afnemen, omdat niet voldoende nesten gevonden worden of vervolglegsels het nestverlies compenseren;

- In de loop der tijd in effectiviteit afneemt.

Een voor dat doel opgesteld landelijk populatiemodel voor de grauwe gans:

- Het onklaar maken van eieren niet geschikt is om de populatieomvang te reduceren, omdat hiervoor onrealistisch hoge fracties/aantallen nesten onklaar gemaakt moeten worden.

- Ganzen onttrekken in bijvoorbeeld de ruiperiode lijkt een meer uitvoerbare en daarbij effectievere maatregel.

Overwegingen ten aanzien van al of niet oppakken van de onderzoeksvraag.

- Daar waar nestbehandeling serieus gebiedsgericht is uitgevoerd, heeft het niet tot de beoogde effecten geleid.

- Een landelijk populatiemodel suggereert dat nestbehandeling überhaupt geen effectieve, uitvoerbare maatregel is. Onttrekken tijdens de ruiperiode lijkt een beter alternatief.

In dit licht bezien kan een gedachte-experiment worden gedaan wat van het voorgestelde onderzoek in de onderzoeksvraag mag worden verwacht. Overwegende dat de niet-effectiviteit van nestbehandeling vooral kan worden toegeschreven aan niet-gevonden nesten, is het weinig zinvol daar een variant toe te voegen met partiële nestbehandeling, zoals voorgesteld in de onderzoeksvraag. Daarnaast kan ook de vraag worden gesteld of zo'n onderzoek op kleine schaal uitgevoerd überhaupt mogelijk is. Zo worden in de onderzoeksvraag als te onderzoeken ingreep-parameters voorgesteld:

prikken/schudden/rapen/insmeren met (maiskiem)olie en geheel behandelen, of 1 resp. 2 eieren onbehandeld laten. Dit levert inclusief blanco's 13 te vergelijken situaties op: 


\begin{tabular}{lccc} 
Behandeling & Volledig nest & 1 ei onbehandeld & 2 eieren onbehandeld \\
Prikken & 1 & 2 & 3 \\
\hline Schudden & 4 & 5 & 6 \\
\hline Rapen & 7 & 8 & 9 \\
\hline Insmeren & 10 & 11 & 12 \\
\hline Onbehandeld & 13 & $n v t$ & $N v t$
\end{tabular}

Als per behandeling 10 nesten worden gevolgd, gaat het om 130 nesten. Van de nesten/broedparen zal ten minste de herleg en het totale uitkomstpercentage moeten worden vergeleken. De gevonden verschillen zullen moeten worden doorgerekend op de te verwachten omvang van de populatie. Dit geldt voor één soort; voor twee soorten zal de inspanning moeten worden verdubbeld. Verder is denkbaar dat één jaar een onvoldoende representatief beeld zal opleveren van het effect van de maatregel, bijvoorbeeld omdat andere factoren zoals weersomstandigheden de uitkomst van het onderzoek sterk kunnen beïnvloeden. Het is de vraag of dit alles overeenkomt met het beeld van een eenvoudig praktijkgericht onderzoek. Dit nog afgezien van het opstellen een praktijkhandleiding waarbij wellicht iets zal moeten worden gezegd over hoe alle nesten te vinden (wat op Texel niet lukte, ondanks veel moeite) en hoe de behandeling goed uit te voeren (wat in deze onderzoeksopzet niet is opgenomen!). Dit zijn aspecten die bij de praktijk- of uitvoeringsfase aan de orde zijn.

Vraag 3. Wat is het voorlopige beeld?

Bovenstaande overwegingen zijn weinig ondersteunend voor het in uitvoering nemen van de onderzoeksvraag. Daarmee is de hoofdvraag voor deze casus beantwoord: het lijkt niet urgent om deze onderzoeksvraag in uitvoering te nemen.

Hiermee hebben we de onderzoeksvraag zoals beschreven in aanhangsel 1 behandeld en kan dit inzicht als advies worden voorgelegd bij de beslissing om het in uitvoering te nemen.

\section{B. Naar een meer algemene methodiek.}

Die hierboven behandelde vraag was vrij specifiek, een die zo uit de praktijk kwam. Wat kunnen we nu in meer algemene zin leren om tot een beeld te komen of onderzoek wel of niet in uitvoering moet worden?

Essentieel is om

1. het onderzoek goed te positioneren,

2. een scherp beeld te krijgen wat de essentie is van wat men te weten wil komen en welke eisen aan de kwaliteit van het antwoord worden gesteld en

3. nauwkeurig na te gaan tot welk handelingsperspectief de te vergaren inzichten leiden en welk probleem daarmee wordt opgelost (en welke nieuwe problemen evt. ontstaan).

ad 1)

Aan het begin van de notitie is hierover al een en ander opgemerkt. Wat als vuistregel kan worden aangehouden, is dat een praktijkonderzoek (uitvoeringsgericht) pas aan de orde kan zijn als de effectiviteit van de maatregel bewezen is op basis van bewijzend onderzoek. Dat bewijzend onderzoek (naar methode-effectiviteit) kan pas aan de orde zijn als de problematiek voldoende substantieel is.

ad 2)

Dit lijkt misschien een open deur: een scherp beeld krijgen van de essentie van de vraag. Toch is het goed hier expliciet aandacht aan te besteden. Bij de onderzoeksvraag leek de vragensteller ervan uit te gaan dat legselbehandeling op zichzelf een effectieve maatregel is en dat het erom ging dit te optimaliseren. Inzichten uit reeds verricht onderzoek geven aan dat dit niet zo vanzelfsprekend is. De vraag werd door de aanvrager ingeëngd tot die van gedeeltelijke legselbehandeling, terwijl ook de vraag kan worden gesteld is of legselbehandeling in de Nederlandse context überhaupt effectief kan zijn. ad 3)

Daarmee zijn we aanbeland bij het derde punt. Daarbij gaat het erom te doordenken wat het handelingsperspectief wordt als het inzicht er is. In geval van de onderzoeksvraag zou de vraag volgen: stel dat zou blijken dat 2 eieren laten liggen tot het beste resultaat leidt (bijv. 10\% minder jongen dan bij complete nestbehandeling het geval zou zijn), waar zou dat in de praktijk toe leiden? Hoe zit het 
met de populatieomvang van de soort als geheel? Dat zou doorgerekend moeten worden met een populatiemodel en dan zou het zo kunnen zijn dat het effect op de populatieomvang verwaarloosbaar is. Met andere woorden, zelfs bij een significant effect van een bepaalde nestbehandeling (hier een significante verlaging van de productiviteit) kan het uiteindelijke effect nul zijn (hier: geen remmend effect op populatiegroei). Aan de andere kant: zou een plaatselijke afname van de populatie een oplossing kunnen zijn van het probleem als de totale populatieomvang daarbij niet wordt beïnvloed? Kortom, het op te lossen probleem moet scherp worden verwoord.

\section{Nadere beschouwing van de essentie van de vraag}

Dit is misschien wel het belangrijkste punt: wat is de essentie van de vraag en welke kwaliteitseisen stelt men aan het te verkrijgen inzicht?

Een vraag vooraf is: is het probleem substantieel? Dat kan eenvoudig worden nagegaan door de jaarlijkse schadebedragen van de betreffende soort op de wildschadelijst te checken.

Vervolgens komt aan de orde of het voorgestelde verjagingsmiddel potentieel interessant is voor onderzoek. Daarvoor kunnen de volgende vragen dienen:

1. Nieuwswaarde. Is er over dit middel al kennis voorhanden? Voegt het voorgestelde onderzoek wat toe? Zijn er indicaties dat het middel effectief zou kunnen zijn om de schade te beperken? Dat mag in deze fase op intuïtie gebaseerd zijn. Het is goed om deze intuïtie te verwoorden en deze duidelijk te scheiden van de beschikbare wetenschappelijke kennis (zie Buij et al., 2016).

2. Ruimtelijke ambitie relevant? Een volgend aspect is: wat is qua ambitie de aard van het verjagingsmechanisme:

- Pleksgewijze verjaging, dus pleksgewijze voorkoming van de schade;

- De beoogde schaal van verjaging is perceel/bedrijf/polder/regio;

o populatieomvang verandering is wel/niet aan de orde;

o duurzame instandhouding is wel/niet aan de orde.

Doordacht moet worden waarvoor (voor welk probleem) pleksgewijze verjaging een oplossing kan zijn. Dat kan bijvoorbeeld gaan om het sparen van zeer kostbare gewassen, waardoor de verjaagden zich verplaatsen naar minder schadegevoelige gewassen. Als dat niet geval is, dan rijst de vraag of verjaging überhaupt zinvol kan zijn: louter verplaatsing van het probleem naar de buren zal voor de betrokkene afdoende zijn, maar lijkt maatschappelijk weinig zinvol. Bij eventueel onderzoek zal de vraag aan de orde kunnen komen om na te gaan hoe het totale schadeniveau zich zal ontwikkelen.

- Pleksgewijs onttrekken (afschieten, vergassen) aan de populatie;

- De beoogde schaal van de onttrekking is perceel/bedrijf/polder/regio;

o populatieomvang verandering is wel/niet aan de orde;

o duurzame instandhouding is wel/niet aan de orde.

Hier is aantalsverlaging expliciet doel. De vervolgvraag die aan de orde komt, is of de aantalsonttrekking tot een systematisch kleinere populatie leidt en of de staat van instandhouding daarmee in het geding zou kunnen zijn. Als duurzame instandhouding kan worden verbonden met een minimum omvang van de populatie, zal ervoor moeten worden gewaakt dat dit minimumaantal door de onttrekkingsacties niet wordt onderschreden.

3. Wetenschappelijke bewijskracht. Als uit bovenstaande volgt dat onderzoek waardevolle inzichten kan opleveren en dus wenselijk kan zijn, zal de opzet ervan nader uitgewerkt moeten worden. Daarbij kunnen zich tal van aspecten voordoen. Het is hier niet de plaats om dat geheel uit te schrijven. Een paar algemene noties kunnen wel worden genoemd. Als van een verjaagmiddel de effectiviteit eenduidig moet worden vastgesteld met een wetenschappelijke bewijskracht, kan op de volgende punten worden gecheckt:

- experimentele opzet

- Blanco's: het vergelijken van wel en niet te behandelen locaties;

- Voor en na: het vergelijken van de situatie voor en na behandeling (BACI);

- Voldoende aantallen: om statistisch te kunnen onderbouwen zijn voldoende herhalingen nodig;

- Ruimtelijk adequate niveau: als iets op laag ruimtelijk niveau werkt, werkt het niet noodzakelijkerwijs ook op hoog ruimtelijk niveau; 
- Duur van het effect: hoe lang heeft een maatregel effect, hoe vaak zal het middel moeten worden ingezet?

- Aansluiting op de ecologie van de schadesoorten

- Ingrijpen in de distributie, foerageergebieden, het broedsucces of aantallen van een soort betekent ingrijpen in de ecologie. Hoe dat werkt en wat daarbij komt kijken, dient bij de uitwerking van het onderzoek goed te worden meegenomen. Dit kan breed gaan, tot en met de beschouwing van gevolgen voor de staat van instandhouding in het gehele Fly way-gebied. In deel 1 van deze rapportage (par. 5.5) wordt voor de 10 belangrijkste schadesoorten een overzicht gegeven van de wijze waarop verjaging werkt en hoe dit ingrijpt op ecologische en gedragsaspecten.

- Neveneffecten

- Ecologisch, ecotoxicologisch. Bij het verjagen van de schadesoorten kunnen onbedoelde neveneffecten plaatsvinden. Zo kunnen ook andere soorten worden verjaagd of anderszins worden beïnvloed (bijv. via de voedselketen). Wat is de te verwachten omvang en ernst daarvan?

- Milieukwaliteit. Chemische middelen kunnen het milieu aantasten. Getoetst zal moeten worden in hoeverre hier sprake van is of kan zijn.

4. Maatschappelijke aspecten. Aan het toepassen van verjagingsmiddelen zitten ook maatschappelijke en ethische aspecten die in het toelatingstraject aan de orde komen en die al besproken kunnen worden voordat het onderzoek wordt uitgevoerd.

- Maatschappelijke veiligheid. Is het verjagingsmiddel potentieel van invloed op veiligheid (vliegveiligheid) of ziekteverspreiding (vectoren) en zo ja, wat voor implicaties heeft dat voor de toepassing van het middel en daarmee op de uitvoering van het onderzoek?

- Maatschappelijke acceptatie, dier-ethische aspecten. Aan verjagingsmiddelen zijn dier-ethische aspecten verbonden die bij het inzetten van het middel meegenomen moeten worden. Dat kan te maken hebben met dierenleed of een te grote inbreuk op de integriteit. Al of niet in het verlengde daarvan kan ook meer algemeen maatschappelijke acceptatie aan de orde zijn (denk bijv. aan de connotatie van vergassing met een oorlogshandeling; of het gebruik van een geweer om een enkele mus af te schieten - een combinatie met door media versterkte individualisering van het dier).

5. Uitvoeringsaspecten, kosten. Ten slotte zijn ook uitvoeringsaspecten van belang.

- Praktische haalbaarheid. Het gaat hier om de logistieke aspecten van de uitvoering. Dat kan bijvoorbeeld betreffen de beschikbaarheid/inzetbaarheid van voldoende vrijwilligers, of andere logistieke aspecten. Zo zijn jagers bij sommige verjaagacties essentieel, maar omdat het vrijwilligers betreft zijn er grenzen aan plaats, aantal en frequentie van de inzet. Dit aspect kan opzet van het onderzoek of de inzet van de verjaagacties medebepalen. Ook kan het aanleiding zijn om verjaging niet door vrijwilligers maar door professionals te laten uitvoeren. Dat heeft dan weer invloed op de kosten.

- Kosten. Het gaat zowel om de kosten van de uitvoering van het onderzoek als de kosten van het inzetten van de verjagingsmiddelen. Deze zullen afgezet moeten worden tegen de schade die door het wild wordt veroorzaakt, het effect van de verjaging op het schadebedrag en tevens tegen de kosten gemoeid met het zorgen voor een gunstige staat van instandhouding van de soort.

\section{Hoe te komen tot een eindbeeld?}

Hierboven zijn de verschillende aspecten de revue gepasseerd die aan de orde zijn bij het bepalen van de relevantie en kwaliteit van onderzoeken en die bij het in uitvoering van maatregelen een rol kunnen spelen.

Bij het komen tot een eindbeeld zijn verschillende routes mogelijk.

Een eerste route is:

- Is het onderzoek überhaupt relevant (substantieel probleem; relevant kennishiaat, inzicht leidt tot handelingsperspectieven)?

- Is het onderzoek wetenschappelijk deugdelijk van opzet? Gaat het op alle relevante aspecten in?

- Behoeven maatschappelijke aspecten bijzondere aandacht? 
- Hoe verhouden de te maken onderzoeks- en uitvoeringskosten zich tot de omvang van de problematiek en de potentiële oplossing die vanuit de te vergaren inzichten wordt aangedragen?

Elk aspect brengt zijn eigen afwegingskader mee. Het is belangrijk daarover een gezamenlijk stramien af te spreken. De hierboven geschetste reeks zou er één kunnen zijn.

Nu zal er in de praktijk nooit sprake zijn van zwart-witsituaties, maar vaak van 'grijstinten'. Het in het onderzoek te vergaren inzicht lost slechts een deel van het probleem op. De uitvoering lijkt bijvoorbeeld redelijk te doen, maar de kosten zijn aan de hoge kant. Al die aspecten zullen ten opzichte van elkaar moeten worden gewogen. Een die weging zal situatieafhankelijk zijn.

De weging kan eventueel in een Excelsheet plaatsvinden (voorbeeld zie Aanhangsel 2).

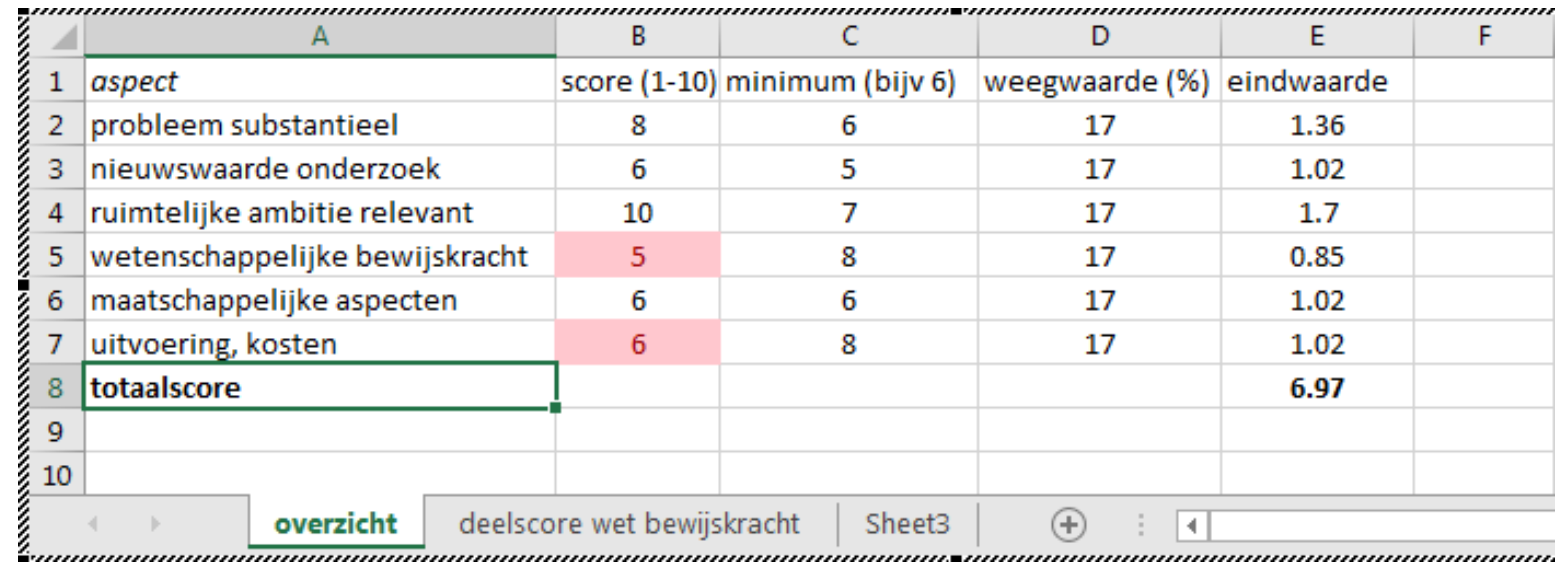

Figuur 1 Screenshot van Exceltabel; tabblad 'overzicht' met scores voor diverse aspecten en totaalscore.

De te wegen aspecten worden daarin opgenomen. Per aspect kan een score worden gegeven. Desgewenst kan een minimum-score worden opgenomen (een soort veto; in de voorbeeldtabel scoren twee aspecten onder de maat: wetenschappelijke bewijskracht en uitvoering/kosten). De verschillende aspecten kunnen t.o.v. elkaar worden gewogen. Deze weegwaarde moet onderling worden overeengekomen. In de tabel worden alle aspecten vooralsnog even zwaar gewogen. De score, in combinatie met de weegwaarde leidt dan tot een eindscore per aspect. Al deze deelscores kunnen bij elkaar worden opgeteld, wat leidt tot de eindscore. Deze eindscore kan in de oordeelsvorming worden meegenomen. Onderstaande tabel geef e.e.a. weer. Merk op dat twee aspecten onder de maat scoren (wetenschappelijke bewijskracht en uitvoeringsaspecten). Men kan eisen dat om tot een eindscore te komen, alle aspecten aan het minimum moeten voldoen. In dit geval moet de wetenschappelijke kwaliteit beter worden en moeten de uitvoeringskosten omlaag.

Nu kan de score van een aspect complex zijn. Dat geldt bijvoorbeeld voor de wetenschappelijke bewijskracht waar diverse aspecten in meespelen. Voor zo'n complex aspect kan met een afzonderlijke tabel de score worden bepaald. Dit is onder het tweede tabblad opgenomen (in de Word-file aan te klikken). Met een dergelijke tabel kan ervaring worden opgedaan. 


\begin{tabular}{|c|c|c|c|c|c|c|c|c|}
\hline 4 & A & & B & c & D & $\mathrm{E}$ & $\mathrm{F}$ & G \\
\hline 1 & aspect wetenschappelij & bewijskracht & score & minir & um weging & eindscore & & \\
\hline 2 & experimentele opzet & & & & & & & \\
\hline 3 & blanko's & & & & & & & \\
\hline 4 & $\mathrm{BACl}$ (voor en na) & & & & & & & \\
\hline 5 & $\mathrm{~N}$ (statistische bewijskr & cht) & & & & & & \\
\hline 6 & ruimtelijk adequaat & & & & & & & \\
\hline 7 & tijdsduur effect & & & & & & & \\
\hline 8 & (ecologische) neveneffe & cten & & & & & & \\
\hline 9 & totaalscore & & & & & & & \\
\hline 10 & & & & & & & & \\
\hline & overzicht & deelscore we & et bew & racht & Sheet3 & ( & 1 & \\
\hline
\end{tabular}

Figuur 2 Screenshot van Exceltabel; tabblad 'deelscore wet bewijskracht' met scores voor diverse aspecten en totaalscore - niet ingevuld. 


\section{Aanhangsel 1 Casus 'effectiviteit legselbehandeling bij ganzen'}

Tot op heden is onduidelijk welke vorm van legselbehandeling bij ganzen het meeste resultaat oplevert. Kortom: dienen alle eieren op een nest te worden behandeld en zo ja, welke wijze is het effectiefst: prikken/schudden/rapen/insmeren met (maiskiem)olie of dient per legsel 1 resp. 2 eieren onbehandeld te worden gelaten ter voorkoming van vervolglegsel? Een kleinschalig praktijkonderzoek dient aan te tonen welke vorm van legselbehandeling het meeste resultaat oplevert. De wens is om praktijkgericht onderzoek uit te voeren op enkele ganzenbroedlocaties, waarbij per maatregel of combinatie van legselbehandelingsmaatregelen de effectiviteit in kaart wordt gebracht. Het verwachte resultaat/product is een praktische handreiking aan FBE's, TBO's en andere uitvoerenden op welke wijze legselreductie het beste kan worden uitgevoerd.

\section{Achtergrond: bevindingen effectiviteit eierrapen op Texel (uit Kleijn et al., 2012).}

De geschatte effectiviteit van het onklaar maken van ganzeneieren op Texel nam af van $70 \%$ in 2009 tot $57 \%$ in 2011. Berekeningen aan het aantal eieren dat jaarlijks onklaar werd gemaakt en het aantal juveniele grauwe ganzen dat desondanks nog vliegvlug werd, suggereren dat deze maatregel wel heeft geleid tot een sterke reductie van het aantal kuikens dat vliegvlug werd. Afgezien van het doden van ruiende ganzen (zie hieronder) blijkt de effectiviteit van het onklaar maken van eieren de belangrijkste factor die, via de aanwas van jonge ganzen, de populatiegroei op Texel bepaalt. Het onklaar maken van eieren is dus wel effectief in het reduceren van de aanwas van de grauwe ganzenpopulatie, maar niet effectief genoeg om de populatiegroei op Texel te stoppen. Ook lijken de resultaten erop te duiden dat de maatregel minder effectief wordt naarmate deze langer wordt toegepast.

Achtergrond: bevindingen effectiviteit diverse maatregelen (uit Baveco et al., 2013). De uitkomsten van de scenarioberekeningen leiden tot de constatering dat de drie onderzochte maatregelen effectief tot een verlaging van de groei van de grauwe ganzenpopulatie leiden. Het onklaar maken van eieren is, als individuele maatregel, echter niet geschikt om de populatieomvang van de grauwe gans te reduceren, omdat hiervoor onrealistisch hoge fracties/aantallen nesten onklaar gemaakt moeten worden. Afschot en/of doden in de ruiperiode zijn effectieve maatregelen waarmee in een relatief korte periode de grauwe ganzenpopulatie gereduceerd kan worden. Dit gaat dan wel gepaard met het doden van (zeer) grote aantallen grauwe ganzen. Jaarrond afschot heeft, ten opzichte van doden in uitsluitend de zomerperiode, als nadeel dat in de winterperiode substantiële aantallen ganzen worden gedood, die buiten Nederland broeden.

De scenarioberekeningen suggereren dat, om de grauwe ganzenpopulatie op een stabiel peil van 100.000 individuen te houden, er jaarlijks 124.000 eieren onklaar gemaakt moeten worden of circa 25.000 grauwe ganzen gedood moeten worden in de zomerperiode of circa 37.000 grauwe ganzen gedood moeten worden met jaar-rond maatregelen (afschot en doden in de ruiperiode). De laatstgenoemde aantallen zijn overigens sterk afhankelijk van de verhouding tussen het aantal ganzen dat in zomer- en winterperiode gedood wordt en het aantal wintermigranten dat Nederland aandoet. Dit zijn uitvoerbare aantallen gezien de aantallen grauwe ganzen die in recente jaren in Nederland zijn gedood in het kader van afschot ter bestrijding van landbouwkundige schade. Bij een omvang van de populatie zoals die anno 2013 in Nederland voorkomt, lijken de effecten van de drie verschillende maatregelen (grotendeels) additief en dit suggereert dat individuele maatregelen minder intensief hoeven te worden uitgevoerd als ze gecombineerd worden met andere maatregelen. 


\section{Aanhangsel 2}

Tabel 1 Excelfile ten behoeve van scoren van onderzoeken.

\begin{tabular}{lcccc} 
aspect & score (1-10) & minimum (bijv 6) & weegwaarde (\%) & eindwaarde \\
probleem substantieel & 8 & 6 & 17 & 1,36 \\
\hline nieuwswaarde onderzoek & 6 & 5 & 17 & 1,02 \\
\hline ruimtelijke ambitie relevant & 10 & 7 & 17 & 1,7 \\
\hline wetenschappelijke bewijskracht & 5 & 8 & 17 & 0,85 \\
\hline maatschappelijke aspecten & 6 & 6 & 17 & 1,02 \\
\hline uitvoering, kosten & 6 & 8 & & 1,02 \\
\hline totaalscore & & & & $\mathbf{6 , 9 7}$ \\
\hline
\end{tabular}




\section{$5 \quad$ Discussie}

\section{Overzicht van het onderzoek}

Bij het opstellen van het overzicht is naar vermogen alle literatuur benut die peer-reviewed is. Dat betreft met name internationaal gepubliceerde artikelen en rapporten. Daarvan geldt de ambitie dat het een compleet overzicht is. Daarnaast is ook het onderzoek betrokken dat door BIJ12 en haar voorgangers is uitgevoerd. In veel gevallen is de wetenschappelijk kwaliteit daarvan niet optimaal, bijvoorbeeld door het ontbreken van statistische toetsen, een uitgebalanceerde experimentele opzet en/of een BACI-opzet. Daardoor komen deze onderzoeken niet alle terug in dit overzicht. Dit kan onbevredigend zijn, bijvoorbeeld omdat men op basis van 'gezond verstand' meent dat de resultaten ervan plausibel zijn en zo'n wetenschappelijke toets overbodig is. Hierover is discussie mogelijk. Zo'n toets van plausibiliteit van onderzoek is uiteraard mogelijk, maar maakt geen deel uit van deze rapportage. In dit overzicht hebben we de criteria gebruikt zoals die in de methodiek zijn beschreven.

\section{Leidraad beoordeling onderzoek}

Bij het opstellen van de leidraad bleek dat niet kon worden volstaan met louter wetenschappelijke criteria. Deze wetenschappelijke criteria zijn in beginsel wel toereikend om gepubliceerde onderzoeken te kunnen beoordelen, maar niet om de wenselijkheid van nieuw uit te voeren onderzoek mee te bepalen. Het is onvermijdelijk dat ook maatschappelijke aspecten daarin een grote rol spelen. Een aantal daarvan is bij het uitwerken van de leidraad meegenomen.

Bij het gebruikmaken van de leidraad dient men nadrukkelijk voor ogen te houden dat het een hulpmiddel is en geen 'machinerie' die tot een eenduidig beeld komt of onderzoek nu wel of niet betekenisvol is. Zo zal men van geval tot geval moeten bepalen wat relevante aspecten zijn die men wil meenemen en zal men zelf alle aspecten moeten wegen. De grote betekenis van de leidraad is dat het kan helpen om de standpuntbepaling te objectiveren en transparant te maken. Werkenderwijs zal die in de praktijk een plek moeten krijgen. 


\section{Conclusies en aanbevelingen}

\section{Overzicht soorten}

Van de top 10 van meest schadelijke soorten is een beschrijving gemaakt van de wetenschappelijke bevindingen rond verjagen en schadereductie. Tevens is een overzicht gemaakt van aanknopingspunten voor verder onderzoek om tot een verdere beheersing van de schade te komen, waarbij tevens mee wordt genomen de duurzame stand van instandhouding. Dit geeft de stand van zaken weer: met behulp van nieuw onderzoek zal gezocht moeten blijven worden naar manieren om op objectieve wijze effectiviteit en kosteneffectiviteit van bestaande en nieuw te ontwikkelen verjagingstechnieken inzichtelijk te maken.

\section{Leidraad beoordeling onderzoek}

Een leidraad is opgesteld om wetenschappelijk onderzoek rond verjaging/schadebestrijding te kunnen beoordelen. Deze leidraad kan tevens worden gebruikt om tot een standpunt te komen over de wenselijkheid van nieuw uit te voeren onderzoek. Deze leidraad kan ook bij wijze van checklist worden gebruikt door diegenen die een verzoek tot onderzoek aan BIJ12 voorleggen. Daarbij is duidelijk dat uiteindelijke standpuntbepaling over de zinvolheid en het benodigde niveau van wetenschappelijke kwaliteit van onderzoek een zaak van het fonds is die niet door anderen kan worden overgenomen. De handreiking/checklist is dus uitdrukkelijk een hulpmiddel, waarvan het fonds zelf 'het stuur' zal moeten vasthouden. Met deze handreiking kan de komende tijd ervaring worden opgedaan. Uit deze (ervarings)praktijk zal blijken wat de gebruikswensen zijn en in welke vorm de checklist het best gebruikt kan worden. 


\section{Literatuur}

Achiron, M., 1968. Building a better scarecrow. Natl. Wildl. 26:18-21.

Aguilera, E., Knight, R. en Cummings, J.L., 1991. An evaluation of two hazing methods for urban Canada geese. Wildl. Soc. Bull. 19:32-35.

Andelt, W.F., Baker, D.L. en Burnham, K.P., 1992. Relative preference of captive cow elk for repellenttreated diets. The Journal of wildlife management, pp.164-173.

Andelt, W.F., Burnham, K.P. en Baker, D.L., 1994. Effectiveness of capsaicin and bitrex repellents for deterring browsing by captive mule deer. The Journal of Wildlife Management, pp.330-334.

Andelt, W.F., Burnham, K.P. en Manning, J.A., 1991. Relative effectiveness of repellents for reducing mule deer damage. The Journal of wildlife management, pp.341-347.

Andrzejewski, R. en Jezierski, W., 1978. Management of a wild boar population and its effects on commercial land. Acta theriologica, 23(19), pp.309-339.

Askham, L.R., 1990. March. Effect of artificial perches and nests in attracting raptors to orchards. In Proceedings of the Fourteenth Vertebrate Pest Conference 1990 (p. 2).

Aubin, T., 1990. Synthetic bird calls and their application to scaring methods. Ibis 132:290-299.

Baettig, M., 1988. Recherche et étude du sanglier dans la République et Canton du Jura. Biologie, habitat, chasse et gestion, dégâts aux cultures et leur prévention. Office des eaux et de la protection de la nature, St-Ursanne, Switzerland.

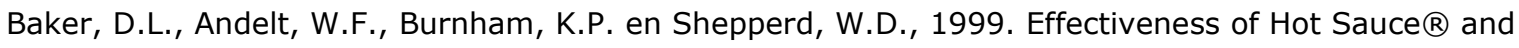

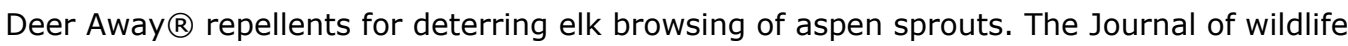
management, pp.1327-1336.

Baker, S.E., Ellwood, S.A., Slater, D., Watkins, R.W. en Macdonald, D.W., 2008. Food aversion plus odor cue protects crop from wild mammals. Journal of Wildlife Management, 72(3), pp.785-791.

Baker, S.E., Ellwood, S.A., Watkins, R. en MacDonald, D.W., 2005a. Non-lethal control of wildlife: using chemical repellents as feeding deterrents for the European badger Meles meles. Journal of Applied Ecology, 42(5), pp.921-931.

Baker, S.E., Ellwood, S.A., Watkins, R.W. en Macdonald, D.W., 2005b. A dose-response trial with ziram-treated maize and free-ranging European badgers Meles meles. Applied Animal Behaviour Science, 93(3), pp.309-321.

Bauman, P.J., Jenks, J.A. en Roddy, D.E., 1999. Evaluating techniques to monitor elk movement across fence lines. Wildlife Society Bulletin (1973-2006), 27(2), pp.344-352.

Baveco, J.M., Kuipers, H. en Nolet, B.A., 2011. A large-scale multi-species spatial depletion model for overwintering waterfowl. Ecological Modelling, 222(20), pp.3773-3784.

Baveco, J.M., D. Kleijn, H.J. de Lange, D.R. Lammertsma, B. Voslamber en Th.C.P. Melman, 2012. Populatiemodel voor Grauwe Gans; enkele scenarioberekeningen voor aantalsregulatie Grauwe Gans. Wageningen, Alterra, Alterra-rapport 2445.

Baveco, J.M., D. Kleijn, H.J. d. Lange, D.R. Lammertsma, B. Voslamber en T.C.P. Melman, 2013. Populatiemodel voor de Grauwe gans : enkele scenarioberekeningen voor aantalsregulatie. Alterrarapport Alterra-rapport 2445. Alterra Wageningen-UR.

Bélanger, L. en Bédard, J., 1989. Responses of staging greater snow geese to human disturbance. The Journal of Wildlife Management, pp.713-719.

Belant, J.L., Seamans, T.W. en Tyson, L.A., 1998, January. Evaluation of electronic frightening devices as white-tailed deer deterrents. In Proceedings of the Eighteenth Vertebrate Pest Conference 1998 p. 3.

Beringer, J., VerCauteren, K.C. en Millspaugh, J.J., 2003. Evaluation of an animal-activated scarecrow and a monofilament fence for reducing deer use of soybean fields. Wildlife Society Bulletin, pp.492498.

Bieber, C. en Ruf, T., 2005. Population dynamics in wild boar Sus scrofa: ecology, elasticity of growth rate and implications for the management of pulsed resource consumers. Journal of Applied Ecology, 42(6), pp.1203-1213.

Bijlsma, R.G., 1993. Ecologische atlas van de Nederlandse roofvogels. Schuyt en Co., Haarlem. 
Bishop, J., McKay, H., Parrott, D. en Allan, J., 2003. Review of international research literature regarding the effectiveness of auditory bird scaring techniques and potential alternatives. Food and Rural Affairs, York, UK.

Blackwell, B.F., Bernhardt, G.E. en Dolbeer, R.A., 2002. Lasers as nonlethal avian repellents. The Journal of Wildlife Management, pp.250-258.

Bleier, N., Imre Kovács, Gergely Schally, László Szemethy en Sándor Csányi, 2017. Spatial and temporal characteristics of the damage caused by wild ungulates in maize (Zea mays L.) crops, International Journal of Pest Management, 63:1, 92-100, DOI: 10.1080/09670874.2016.1227487

Bobek, B., Furtek, J., Bobek, J., Merta, D. en Wojciuch-Ploskonka, M., 2017. Spatio-temporal characteristics of crop damage caused by wild boar in north-eastern Poland. Crop Protection 93: 106-112.

Bomford, M. en O'Brien, P.H., 1990. Sonic deterrents in animal damage control: a review of device tests and effectiveness. Wildlife Society Bulletin (1973-2006), 18(4), pp.411-422.

Bomford, M. en Sinclair, R., 2002. Australian research on bird pests: impact, management and future directions. Emu, 102(1), pp.29-45.

Bomford, M., 1992. March. Review of research on control of bird pests in Australia. In Proceedings of the fifteenth vertebrate pest conference 1992 (p. 9).

Bommel, van F., 2016. Overzicht preventieve maatregelen ter voorkoming mezenschade aan fruit. Van Bommel FAUNAWERK, Versie 11 april 2016.

Bos, D.A.A.N. en Stahl, J.U.L.I.A., 2003. Creating new foraging opportunities for Dark-bellied Brent Branta bernicla and Barnacle Geese Branta leucopsis in spring-insights from a large-scale experiment. Ardea, 91(2), pp.153-166.

Boudewijn, T.J., Beuker, D. en Tanger, D., 2008. Proef weren nachtelijk foeragerende smienten met een laser. Bureau Waardenburg, Culemborg 08-046.

Boudewijn, T.J., Tanger, D., Beuker, D. en Steendam, H., 2007. Onderzoek naar het weren van smienten met behulp van holografische strips. Bureau Waardenburg, Culemborg.

Bradford, J.B. en Hobbs, N.T., 2008. Regulating overabundant ungulate populations: an example for elk in Rocky Mountain National Park, Colorado. Journal of Environmental Management, 86(3), pp.520528.

Breton, D., 1994. La limitation des dégâts de sanglier par la pose de clôtures électriques dans le département de la Haute-Marne. Bull Mens Off Natl Chasse, 191, pp.96-100.

Briedermann, L., 1990. Schwarzwild, second ed. NeumannNeudamm, Melsungen.

Buij, R., D.R. Lammertsma en Th.C.P. Melman, 2016. Effectiviteit wildschadepreventie; Beoordelingsmethodiek en literatuurreview. Alterra-rapport 2740. Alterra, Wageningen-UR.

Calenge, C., Maillard, D., Fournier, P. en Fouque, C., 2004. Efficiency of spreading maize in the garrigues to reduce wild boar (Sus scrofa) damage to Mediterranean vineyards. European Journal of Wildlife Research, 50(3), pp.112-120.

Castelli, P.M. en Sleggs, S.E., 2000. Efficacy of border collies to control nuisance Canada geese. Wildlife Society Bulletin, pp.385-392.

Cellina, S., 2008. Effects of supplemental feeding on the body condition and reproductive state of wild boar Sus scrofa in Luxembourg (Doctoral dissertation, University of Sussex).

Cepek, J.D., Suckow, J., Croson, C. en Blackwell, B.F., 2001. Laser dispersal of Canada geese at Lake Galena, Pennsylvania. United States Department of Agriculture/Animal and Plant Health Inspection Service/Wildlife Services/National Wildlife Research Center, Summary Report, Sandusky, Ohio, USA.

Conover, M.R. en Perito, J.J., 1981. Response of starlings to distress calls and predator models holding conspecific prey. Ethology, 57(2), pp.163-172.

Conover, M.R., 1979. Response of birds to raptor models.

Conover, M.R., 1982. Behavioral techniques to reduce bird damage to blueberries: methiocarb and a hawk-kite predator model. Wildlife Society Bulletin, pp.211-216.

Conover, M.R., 1984. Comparative effectiveness of avitrol, exploders, and hawk-kites in reducing blackbird damage to corn. The journal of wildlife management, pp.109-116.

Conover, M.R., 1984. Effectiveness of repellents in reducing deer damage in nurseries. Wildlife Society Bulletin (1973-2006), 12(4), pp.399-404.

Conover, M.R., 1985. Protecting vegetables from crows using an animated crow-killing owl model. The Journal of Wildlife Management, 49(3), pp.643-645.

Conover, M.R., 1992. Ecological approach to managing problems caused by urban Canada geese. 
Cresswell, W., 1994. Age-dependent choice of redshank Tringa totanus feeding location: profitability or risk?. Journal of Animal Ecology, 589-600.

Cresswell, W., 2008. Non-lethal effects of predation in birds. Ibis, 150(1), pp.3-17.

Cummings, J.L., Mason, J.R., Otis, D.L. en Heisterberg, J.F., 1991. Evaluation of dimethyl and methyl anthranilate as a Canada goose repellent on grass. Wildlife Society Bulletin (1973-2006), 19(2), pp.184-190.

Davison, J., Huck, M., Delahay, R.J. en Roper, T.J., 2008. Urban badger setts: characteristics, patterns of use and management implications. Journal of Zoology, 275(2), pp.190-200.

DEFRA, 2006. Development of a strategy for resolving urban badger damage problems. Defra project code WM0304.

DeHaven, R.W., 1971. Blackbirds and the California rice crop. Rice J. 74:11-12,14.

Delahay, R.J., Davison, J., Poole, D.W., Matthews, A.J., Wilson, C.J., Heydon, M.J. en Roper, T.J., 2009. Managing conflict between humans and wildlife: trends in licensed operations to resolve problems with badgers Meles meles in England. Mammal Review, 39(1), pp.53-66.

DeNicola, A.J., VerCauteren, K.C., Curtis, P.D. en Hyngstrom, S.E., 2000. Managing white-tailed deer in suburban environments. Cornell Cooperative Extension.

Dolbeer, R.A., Woronecki, P.P. en Bruggers, R.L., 1986. Reflecting tapes repel blackbirds from millet, sunflowers, and sweet corn. Wildlife Society Bulletin (1973-2006), 14(4), pp.418-425.

Drake, D. en Villano, A., 2005. Effectiveness of flagging and propane cannons to disperse Canada geese in winter wheat fields. Journal of Extension, 43(2).

Dulos, A. en Visser, M.E., 2006. Schade door mezen aan fruit. NIOO-rapport. Heteren.

Ebbinge, B.S., 1991. The impact of hunting on mortality rates and spatial distribution of geese wintering in the Western Palearctic. Ardea, 79(2), pp.197-210.

Eerden, M.R. van, 1990. The solution of goose damage problems in the Netherlands, with special reference to compensation schemes. Ibis, 132(2), pp.253-261.

Elmeros, M., Winbladh, J.K., Andersen, P.N., Madsen, A.B. en Christensen, J.T., 2011. Effectiveness of odour repellents on red deer (Cervus elaphus) and roe deer (Capreolus capreolus): a field test. European journal of wildlife research, 57(6), pp.1223-1226.

Faunaschade Preventie Kit. Module das., 2016. Versie 3.3. https://www.bij12.nl/onderwerpen/faunazaken/faunaschade-preventiekit-fpk/module-das/

Faunaschade Preventie Kit. Module hertachtigen, 2016. Versie 1.1. https://www.bij12.nl/assets/Faunaschade-Preventie-Kit-Hertachtigen-1.1-20161220.pdf

Fernandez, I., 2012. Effectiviteit van het wildraster in Putten. Infofauna 2012-03.

Fox, A.D., Elmberg, J., Tombre, I.M. en Hessel, R., 2017. Agriculture and herbivorous waterfowl: A review of the scientific basis for improved management. Biological Reviews, 92(2), pp.854-877.

Frings, H. en Frings, M., 1967. Behavioral manipulation (visual. mechanical, and acoustical). In: Kilgore, W.W., Doutt, R.L. (Eds.), Pest Control. Academic Press, London, pp. 387-454.

Fuller-Perrine, L.D. en Tobin, M.E., 1993. A method for applying and removing bird-exclusion netting in commercial vineyards. Wildlife Society Bulletin (1973-2006), 21(1), pp.47-51.

Geisser, H. en Reyer, H.U., 2004. Efficacy of hunting, feeding, and fencing to reduce crop damage by wild boars. Journal of Wildlife Management, 68(4), pp.939-946.

Gill, J.A., Watkinson, A.R. en Sutherland, W.J., 1996. The impact of sugar beet farming practice on wintering pink-footed goose Anser brachyrhynchus populations. Biological Conservation, 76(2), pp.95-100.

Gilsdorf, J.M., Hygnstrom, S.E., VerCauteren, K.C., Clements, G.M., Blankenship, E.E. en Engeman, R.M., 2004. Evaluation of a deer-activated bio-acoustic frightening device for reducing deer damage in cornfields. Wildlife Society Bulletin, 32(2), pp.515-523.

Goddard, P.J., Summers, R.W., Macdonald, A.J., Murray, C. en Fawcett, A.R., 2001. Behavioural responses of red deer to fences of five different designs. Applied animal behaviour science, 73(4), pp. 289-298.

Groot Bruinderink, G., 1989. The impact of wild geese visiting improved grasslands in the Netherlands. Journal of Applied Ecology, pp.131-146.

Groot Bruinderink, G.W.T.A., 2008. Toepasbaarheid in Nederland van afweer- en lokmiddelen voor wilde zwijnen (Sus scrofa L.). Alterra-rapport 1739, Wageningen.

Groot Bruinderink, G.W.T.A., Griffioen, A.J., Kuipers, H., Kuiters, A.T. en Lammertsma, D.R., 2005. Edelherten in de Gelderse Poort. Haalbaarheidsstudie. Alterra-rapport 1153, Wageningen. 
Groot Bruinderink, G.W.T.A., Lammertsma, D.R., Jagers op Akkerhuis, G.A.J.M., Ozinga, W., Stumpel, A.H.P., Baveco, J.M. en Waal, R.W. de, 2009. Ex ante evaluatie van maatwerk beheer van wilde zwijnen. Alterra-rapport 1944, Wageningen.

Guldemond, A., Dijkman, W. en Keuper, D., 2015. Wilde zwijnen op weg in Nederland. Analyse van ontwikkelingen in waardering, schade en risico's en aanbevelingen voor beleid en uitvoering. CLM 873.

Gunterschulze, J., 1979. Studien zur Kenntnis der Regio olfactoria von Wild-und Hausschwein. Zool Anz (Jena) 202(3/4):256-279.

Hafidzi, M.N. en Mohd Na Im, 2003. The use of the barn owl, Tylo alba, to suppress rat damage in rice fields in Malaysia. ACIAR MONOGRAPH SERIES 96: 274-276.

Hahn, N. en Eisfeld, D., 1998. Diet and habitat use of wild boar (Sus scrofa) in SW-Germany. Gibier Faune Sauvage, 15, pp.595-606.

Harris, M.T., Palmer, W.L. en George, J.L., 1983. Preliminary screening of white-tailed deer repellents. The Journal of Wildlife Management, 47(2), pp.516-519.

Harris, R.E. en Davis, R.A., 1998. Evaluation of the efficacy of products and techniques for airport bird control. LGL Limited for Aerodrome Safety Branch, Transport Canada.

Heinrich, J.W. en Craven, S.R., 1990. Evaluation of three damage abatement techniques for Canada geese. Wildlife Society Bulletin (1973-2006), 18(4), pp.405-410.

Helmus, P., 2013. Hagelnetten in de Nederlandse perenteelt: effecten, toepasbaarheid en rendabiliteit. CLM 845-2013. CLM Onderzoek en Advies, Culemborg.

Herrnstadt, Z., Howard, P.H., Oh, C.O. en Lindell, C.A., 2016. Consumer preferences for 'natural' agricultural practices: Assessing methods to manage bird pests. Renewable Agriculture and Food Systems, 31(6), pp.516-523.

Holevinski, R.A., Curtis, P.D. en Malecki, R.A., 2007. Hazing of Canada geese is unlikely to reduce nuisance populations in urban and suburban communities. Human-Wildlife Conflicts, 1(2), pp.257-264.

Hollander, H. en La Haye, M., 2014. Dassenschade en -preventie. Rapport 2013.011. Zoogdiervereniging, Nijmegen.

Hollander, H., 2016. Afleidend voeren bij de das als preventieve maatregel. Rapport 2016.18. Bureau van de Zoogdiervereniging, Nijmegen.

Hothem, R.L. en DeHaven, R.W., 1982. Raptor-mimicking kites for reducing bird damage to wine grapes.

Houston, A.I., McNamara, J.M. en Hutchinson, J.M., 1993. General results concerning the trade-off between gaining energy and avoiding predation. Philosophical Transactions of the Royal Society of London B: Biological Sciences, 341(1298), pp.375-397.

Hygnstrom, S.E. en Craven, S.R., 1988. Electric fences and commercial repellents for reducing deer damage in cornfields. Wildlife Society Bulletin (1973-2006), 16(3), pp.291-296.

Inglis, I.R., 1980. Visual bird scarers: an ethological approach. In: Bird Problems in Agriculture ed. E.N. Wright, I.R. Inglis en C.J. Feare, 121-143. British Crop Protection Council, Croydon.

Ingram, C., 1933. Cattle feeding on geese droppings. British Birds 26: 309-310.

Kampen, J., 2006. Onderzoek naar de effectiviteit van holografische strippen als middel om ganzen te weren. Aqua Terra Water en Bodem. Stellendam.

Kay, B.J., Twigg, L.E., Korn, T.J. en Nicol, H.I., 1994. The use of artifical perches to increase predation on house mice (Mus domesticus) by raptors. Wildlife research, 21(1), pp.95-105.

Kemper, S., 1995. What's good for the goose may not be good for you. Smithsonian, 25(10), pp.70-78.

Kendall, R.J., Brewer, L.W. en Hitchcock, R.R., 1993. Response of Canada geese to a turf application of Diazinon AG500. Journal of Wildlife Diseases, 29(3), pp.458-464.

Kendall, R.J., Brewer, L.W., Hitchcock, R.R. en Mayer, J.R., 1992. American wigeon mortality associated with turf application of diazinon AG500. Journal of Wildlife Diseases, 28(2), pp.263-267.

Killian, G., Kreeger, T.J., Rhyan, J., Fagerstone, K. en Miller, L., 2009. Observations on the use of GonaConTM in captive female elk (Cervus elaphus). Journal of wildlife diseases, 45(1), pp.184-188.

Kimball, B.A., Taylor, J., Perry, K.R. en Capelli, C., 2009. Deer responses to repellent stimuli. Journal of chemical ecology, 35(12), pp.1461-1470.

Kleijn, D., Jansman, H.A., Oord, J.G. en Ebbinge, B.S., 2008. Evaluatie Opvangbeleid 2005-2008 overwinterende ganzen en smienten. Deelrapport 9. Effectiviteit verjaagmethoden in foerageergebieden met speciale aandacht voor verjaging met ondersteunend afschot No. 1792. Alterra. 
Kleijn, D., Knecht, E. en Ebbinge, B.S., 2009. Evaluatie Opvangbeleid 2005-2008 overwinterende ganzen en smienten.

Kleijn, D., M. van Riel en T.C.P. Melman, 2011. Pilot onderzoek Grauwe ganzen op Texel; effectiviteit van beheersmaatregelen en ontwikkelingen in landbouw- en natuurschade. Wageningen, Alterra, Alterra-rapport 2307

Kleijn, D., J. van der Hout, H.A.H. Jansman, D. Lammertsma en T.C.P. Melman, 2011. Brandganzen en Kleine Mantelmeeuwen in het Wormer- en Jisperveld. Effecten op weidevogels. Alterra-rapport 2293, Alterra, Wageningen-UR.

Kleijn, D., J.J. v. d. Hout, H.A.H. Jansman, D.R. Lammertsma and T.C.P. Melman, 2012. Brandganzen en Kleine Mantelmeeuwen in het Wormer- en Jisperveld: effecten op weidevogels. Alterra-rapport 2293. Alterra, Wageningen-UR.

Klem Jr, D., 2007. Ecological consequences of artificial night lighting. The Wilson Journal of Ornithology, 119(3), pp.519-521.

Koehler, A.E., Marsh, R.E. en Salmon, T.P., 1990. Frightening methods and devices/stimuli to prevent mammal damage--a review.

Koffijberg, K., Schekkerman, H., van der Jeugd, H., Hornman, M. en van Winden, E., 2017. Responses of wintering geese to the designation of goose foraging areas in The Netherlands. Ambio, 46(2), pp. 241-250.

Kross, S.M., Tylianakis, J.M. en Nelson, X.J., 2012. Effects of introducing threatened falcons into vineyards on abundance of passeriformes and bird damage to grapes. Conservation Biology, 26(1), pp.142-149.

Kuiper, M.W. en van Wieren, S.E., 2010. Contraceptie als methode in het beheer van hoefdierpopulaties. Resource Ecology Group, Wageningen Universiteit.

La Haye, M. en Vink, H., 2016. Das Meles meles. In: Broekhuizen, S. K. Spoelstra, J.B.M. Thissen en J.C. Buys (red). De Nederlandse zoogdieren. Natuur van Nederland 12. Naturalis Biodiversity Center en EIS Kenniscentrum Insecten en ongewervelden, Leiden: 244-246.

Labuschagne, L., Swanepoel, L.H., Taylor, P.J., Belmain, S.R. en Keith, M., 2016. Are avian predators effective biological control agents for rodent pest management in agricultural systems?. Biological Control, 101, pp.94-102.

Lammertsma, D.R. en Jansman, H.A.H., 2016. Quickscan Contraceptie Hoefdieren. Alterra Wageningen UR - Team Dierecologie, Wageningen

Lane, S.J. en Nakamura, K., 1996. The effect of night grazing by wigeon (Anas penelope) on wintersown wheat in Japan and the efficacy of black plastic flags as scaring devices. Agriculture, ecosystems en environment, 59(1), pp.81-87.

Latour, J.B. en Stahl, J., 2018. Praktijkproef inzet lasers voor beperking ganzen- schade. AenW-rapport 2388, Sovon rapport 2018/08. In concept.

Lavoie, G.K. en Glahn, J.F., 1977. Ultrasound as a deterrent to Rattus norvegicus. Journal of stored products research, 13(1), pp.23-28.

Liere, D.W. van, Loonen, M.J.J.E. en Eekeren, N.J.M. van, 2004. Grauwe ganzen leren gras te mijden. Projectrapportage voor het jaar 2004 in opdracht van het Faunafonds.

Lima, S.L., Valone, T.J. en Caraco, T., 1985. Foraging-efficiency-predation-risk trade-off in the grey squirrel. Animal Behaviour, 33(1), pp.155-165.

Lipcius, R.N., Coyne, C.A., Fairbanks, B.A., Hammond, D.H., Mohan, P.J., Nixon, D.J., Staskiwiezc, J.J. en Heppner, F.N., 1980. Avoidance response of mallards to colored and black water. J. Wildl. Manage. 44:511-518.

Lustick, S., 1973, October. The effect of intense light on bird behavior and physiology. In Bird Control Seminars Proceedings (p. 119)

MacLean, R.A., Mathews, N.E., Grove, D.M., Frank, E.S. en Paul-Murphy, J., 2006. Surgical technique for tubal ligation in white-tailed deer (Odocoileus virginianus). Journal of Zoo and Wildlife Medicine, 37(3), pp.354-360.

Madsen, J., 1995. Impacts of disturbance on migratory waterfowl. Ibis, 137(s1).

Malcolm, K.D., Van Deelen, T.R., Drake, D., Kesler, D.J. en VerCauteren, K.C., 2010. Contraceptive efficacy of a novel intrauterine device (IUD) in white-tailed deer. Animal Reproduction Science, 117(3), pp.261-265.

Marsh, R.E., Erickson, W.A. en Salmon, T.P., 1991. Bird Hazing and Frightening Methods and Techniques (with emphasis on containment ponds). 
Marsh, R.E., Erickson, W.A. en Salmon, T.P., 1992. Scarecrows and predator models for frightening birds from specific areas.

Mason, J.R. en Clark, L., 1995. Evaluation of methyl anthranilate and activated charcoal as snow goose grazing deterrents. Crop Protection, 14(6), pp.467-469.

Mason, J.R., Clark, L. en Bean, N.J., 1993. White plastic flags repel snow geese (Chen caerulescens). Crop Protection, 12(7), pp.497-500.

Matthews, A.J. en C.J. Wilson, 2005. The management of problems involving badgers (Meles meles). Protection of Badgers Act 1992 licensing cases 1997-1999. Department for Environment, Food, and Rural Affairs. London, U.K. 22 pp.

McKay, H.V. en Parrott, D., 2002. Mute swan grazing on winter crops: evaluation of three grazing deterrents on oilseed rape. International Journal of Pest Management, 48(3), pp.189-194.

McKillop, I.G. en Sibly, R.M., 1988. Animal behaviour at electric fences and the implications for management. Mammal Review, 18(2), pp.91-103.

McLennan, J.A., Langham, N.P.E. en Porter, R.E.R., 1995. Deterrent effect of eye-spot balls on birds. New Zealand Journal of Crop and Horticultural Science, 23(2), pp.139-144.

McPeek, M.A., 2004. The growth/predation risk trade-off: so what is the mechanism?. The American Naturalist, 163(5), pp.E88-E111.

Melman, Th.C.P., Buij, R. en Koffijberg, K., 2017. Ganzenoverlast, perceptie en oplossingen. De Levende Natuur, 2017 (dec): 216-219.

Meyrom, K., Motro, Y., Leshem, Y., Aviel, S., Izhaki, I., Argyle, F. en Charter, M., 2009. Nest-box use by the Barn Owl Tyto alba in a biological pest control program in the Beit She'an valley, Israel. Ardea, 97(4), pp.463-467.

Mols, C.M., en Visser, M.E., 2002. Great tits can reduce caterpillar damage in apple orchards. Journal of applied ecology, 396, 888-899.

Mols, C.M. en Visser, M.E., 2007. Great tits (Parus major) reduce caterpillar damage in commercial apple orchards. PLoS One, 2(2), p.e202.

Mols, C.M., van Noordwijk, A.J. en Visser, M.E., 2005. Assessing the reduction of caterpillar numbers by Great Tits Parus major breeding in apple orchards. ARDEA-WAGENINGEN-, 93(2), p. 259.

Mott, D.F. en Timbrook, S.K., 1988. Alleviating nuisance Canada goose problems with acoustical stimuli.

Murakami, M. en Nakano, S., 2000. Species-specific bird functions in a forest-canopy food web. Proceedings of the Royal Society B: Biological Sciences, 267(1453), p.1597.

Nolet, B.A., Kölzsch, A., Elderenbosch, M. en Noordwijk, A.J., 2016. Scaring waterfowl as a management tool: how much more do geese forage after disturbance?. Journal of Applied Ecology, 53(5), pp.1413-1421.

Nolte, D.L., 1999. Behavioral approaches for limiting depredation by wild ungulates. Grazing behavior of livestock and wildlife, pp.60-69.

Oord, J.G., 2002. Handboek faunaschade.

Oord, J.G., 2009. Handreiking faunaschade.

Oord, J.G., Ebbinge, B.S., Koers, M. en Goedhart, P.W., 2011. Pilot verjaging ganzen met border collies. Effect van het verjagen met border collies op de verspreiding van ganzen in ZW-Friesland in 2009/2010. Faunafonds.

Owen, M., 1977. The role of wildfowl refuges on agricultural land in lessening the conflict between farmers and geese in Britain. Biological Conservation, 11(3), pp.209-222.

Palmer, W.L., Wingard, R.G. en George, J.L., 1983. Evaluation of white-tailed deer repellents. Wildlife Society Bulletin (1973-2006), 11(2), pp.164-166.

Parrott, D. en Watola, G., 2008. Deterring mute swans from fields of oilseed rape using suspended high visibility tape. Crop protection, 27(3), pp.632-637.

Patterson, I.J. en Fuchs, R.M.E., 2001. The use of nitrogen fertilizer on alternative grassland feeding refuges for pink-footed geese in spring. Journal of Applied Ecology, 38(3), pp.637-646.

Paz, A., Jareño, D., Arroyo, L., Viñuela, J., Arroyo, B., Mougeot, F., Luque-Larena, J.J. en Fargallo, J.A., 2013. Avian predators as a biological control system of common vole (Microtus arvalis) populations in north-western Spain: experimental set-up and preliminary results. Pest management science, 69(3), pp.444-450.

Percival, S.M., 1993. The effects of reseeding, fertilizer application and disturbance on the use of grasslands by barnacle geese, and the implications for refuge management. Journal of Applied Ecology, pp.437-443. 
Percival, S.M., Halpin, Y. en Houston, D.C., 1997. Managing the distribution of barnacle geese on Islay, Scotland, through deliberate human disturbance. Biological Conservation, 82(3), pp.273-277.

Poole, D.W. en McKillop, I.G., 1999. Comparison of the effectiveness of two types of electric fences to exclude badgers. Crop Protection, 18(1), pp.61-66.

Poole, D.W., McKillop, I.G., Western, G., Hancocks, P.J. en Packer, J.J., 2002. Effectiveness of an electric fence to reduce badger (Meles meles) damage to field crops. Crop Protection, 21(5), pp.409-417.

Poole, D.W., Western, G. en McKillop, I.G., 2004. The effects of fence voltage and the type of conducting wire on the efficacy of an electric fence to exclude badgers (Meles meles). Crop protection, 23(1), pp.27-33.

Putman, R.J. en Staines, B.W., 2004. Supplementary winter feeding of wild red deer Cervus elaphus in Europe and North America: justifications, feeding practice and effectiveness. Mammal Review 34(4): 285-306.

Radtke, T.M. en Dieter, C.D., 2011. Canada goose crop damage abatement in South Dakota. HumanWildlife Interactions, 5(2), p.315.

Remijnse, W. en Bommel, F. van, 2010. Verslag van de pilot voor het weren van wilde zwijnen op grasland door middel van het Wasol systeem. Bestuursvergadering Faunafonds 2 september 2010.

Rensel, L.J. en Wilder, J.D., 2012. The effects of owl decoys and non-threatening objects on bird feeding behavior. Quercus: Linfield Journal of Undergraduate Research, 1(1), p.4.

Sanz, J.J., 2001. Experimentally increased insectivorous bird density results in a reduction of caterpillar density and leaf damage to Pyrenean oak. Ecological Research, 16(3), pp.387-394.

Schlageter, A. en Haag-Wackernagel, D., 2012. Evaluation of an odor repellent for protecting crops from wild boar damage. Journal of pest science, 85(2), pp.209-215.

Schley, L., Dufrêne, M. en Krier, A., 2008. Patterns of crop damage by wild boar (Sus scrofa) in Luxembourg over a 10-year period. Eur J Wildl Res 54: 589-599.

Seamans, T.W. en Bernhardt, G.E., 2004. Response of Canada geese to a dead goose effigy.

Seamans, T.W. en Helon, D.A., 2008. Evaluation of an electrified mat as a white-tailed deer (Odocoileus virginianus) barrier. International Journal of Pest Management, 54(1), pp.89-94.

Seamans, T.W., Blackwell, B.F. en Cepek, J.D., 2002. Coyote hair as an area repellent for white-tailed deer. International Journal of Pest Management, 48(4), pp.301-306.

Shumake, S.A., Kolz, A.L., Crane, K.A. en Johnson, R.E., 1982. Variables affecting ultrasound repellency in Philippine rats. The Journal of Wildlife Management, pp.148-155.

Simonsen, C.E., Madsen, J., Tombre, I.M. en Nabe-Nielsen, J., 2016. Is it worthwhile scaring geese to alleviate damage to crops?-An experimental study. Journal of Applied Ecology, 53(3), pp.916-924.

Slater, P.J.B., 1980. Bird behaviour and scaring by sounds. Bird problems in agriculture, pp.105-114.

Spurgeon, D.J., Keith, A.M., Schmidt, O., Lammertsma, D.R. and Faber, J.H., 2013. Land-use and landmanagement change: relationships with earthworm and fungi communities and soil structuraproperties. BMC Ecology DOI: 10.1186/10.1186/1472-6785-13-46 URL: http://www.biomedcentral.com/1472-6785/13/46

Stahl, J., van den Bremer, L., Schekkerman, H., de Boer, V. en Voslamber, B., 2013. Beheer van zomerganzen in de Provincie Utrecht. Sovon-rapport 2013/28. Sovon Vogelonderzoek Nederland, Nijmegen.

Steen, K.A., Therkildsen, O.R., Karstoft, H. en Green, O., 2014. Audio-based detection and recognition of conflict species in outdoor environments using pattern recognition methods. Applied Engineering in Agriculture, 30(1), pp.89-96.

Stevens, G.R., Rogue, J., Weber, R. en Clark, L., 2000. Evaluation of a radar-activated, demandperformance bird hazing system. International biodeterioration en biodegradation, 45(3), pp.129-137.

Summers, R.W. en Hillman, G., 1990. Scaring brent geese Branta bernicla from fields of winter wheat with tape. Crop Protection, 9(6), pp.459-462.

Summers, R.W., 1985. The effect of scarers on the presence of starlings (Sturnus vulgaris) in cherry orchards. Crop Protection, 4(4), pp.520-528.

Swihart, R.K. en Conover, M.R., 1990. Reducing Deer Damage to Yews and Apple Trees: Testing Big Game Repellent $\AA,<$ tex-math $>\backslash \mathrm{rmRO} \wedge \cdot</$ tex-math $>$ pel $\AA$, and Soap as Repellents. Wildlife Society Bulletin (1973-2006), 18(2), pp.156-162.

Swihart, R.K., Pignatello, J.J. en Mattina, M.J.I., 1991. Aversive responses of white-tailed deer, Odocoileus virginianus, to predator urines. Journal of Chemical Ecology, 17(4), pp.767-777. 
Tobin, M.E., Woronecki, P.P., Dolbeer, R.A. en Bruggers, R.L., 1988. Reflecting tape fails to protect ripening blueberries from bird damage. Wildlife Society Bulletin (1973-2006), 16(3), pp.300-303.

Tolhurst, B.A., Ward, A.I., Delahay, R.J., MacMaster, A.M. en Roper, T.J., 2008. The behavioural responses of badgers (Meles meles) to exclusion from farm buildings using an electric fence. Applied Animal Behaviour Science, 113(1), pp.224-235.

Van Bommel, F., 2016. Overzicht preventieve maatregelen ter voorkoming mezenschade aan fruit. Van Bommel FAUNAWERK Versie 11 april 2016.

Van den Bosch, M., Kloen, H., Lommen, J., 2014. Vogelwering met het 'krekelsysteem' Resultaten verkennende proef in Conferenceperenteelt 2013. CLM Onderzoek en Advies CLM 842-2014.

Van den Bremer, L., en Hallmann, C., 2011. Preventie van vogelschade bij fruitbedrijven; veldtoets met de Firefly bakenkaart op bedrijven met Conference peren. SOVON-onderzoeksrapport 2011/19. SOVON Vogelonderzoek Nederland, Nijmegen.

Van den Bremer, L., de Boer, P. en Klaassen, O., 2009. Preventie van vogelschade bij fruitbedrijven. Verkennende veldtoets met de FireFly Bird Diverter op bedrijven met Conference peren. SOVON onderzoeksrapport 2009/14. SOVON Vogelonderzoek Nederland, Beek-Ubbergen.

Van der Jeugd, H.P. en Kwak, A., 2015. Effecten van beheersjacht op de brandganspopulatie in het noordelijk Deltagebied. Vogeltrekstation rapport 2013-04. Vogeltrekstation, Wageningen.

Van Eerden, M.R., 1990. The solution of goose damage problems in the Netherlands, with special reference to compensation schemes. Ibis, 1322, pp.253-261.

van Liere, D., Loonen, M. en van Eekeren, N., 2006. Grauwe ganzen leren gras te mijden CABwim Consultancy, Aassen.

Van Liere, D.W., Loonen, M.J.J.E. en van Eekeren, N.J.M., 2006. Grauwe ganzen leren gras te mijden. Projectrapportage voor het jaar 2005 in opdracht van het Faunafonds.

Vassant, J., 1994. L'agrainage dissuasif: résultats d'expériences. Bull Mens Off Natl Chasse 191:101-105.

Vassant, J., Jullien, J.M. en Brandt, S., 1992. Reducing wild boar damage to wheat and oats in summer: study of the effectiveness of maize distribution in the forest. Proc 18th IUGB Congr, Global trends in wildlife management, Jagdellonian University, Krakow.

VerCauteren, K.C. en Pipas, M.J., 2003. A review of color vision in white-tailed deer. Wildlife Society Bulletin, pp.684-691.

VerCauteren, K.C., Lavelle, M.J. en Hygnstrom, S., 2006. Fences and deer-damage management: a review of designs and efficacy. Wildlife Society Bulletin, 34(1), pp.191-200.

VerCauteren, K.C., Seward, N.W., Lavelle, M.J., Fischer, J.W. en Phillips, G.E., 2009. Deer guards and bump gates for excluding white-tailed deer from fenced resources. Human-Wildlife Conflicts, 3(1), pp.145-153.

VerCauteren, K.C., Shivik, J.A. en Lavelle, M.J., 2005. Efficacy of an animal-activated frightening device on urban elk and mule deer. Wildlife Society Bulletin, 33(4), pp.1282-1287.

Vickery, J.A. en Summers, R.W., 1992. Cost-effectiveness of scaring brent geese Branta b. bernicla from fields of arable crops by a human bird scarer. Crop Protection, 11(5), pp.480-484.

Voslamber B. 2010. Pilotstudie Grauwe Ganzen (Anser anser) De Deelen, 2007-2009. Onderzoek naar het uitrasteren van een broedpopulatie Grauwe Ganzen met als doel de populatie te beperken en landbouwschade te verminderen. SOVON-onderzoeksrapport 2010/02. SOVON Vogelonderzoek Nederland, Nijmegen

Walter, W.D., Perkins, P.J., Rutberg, A.T. en Kilpatrick, H.J., 2002. Evaluation of immunocontraception in a free-ranging suburban white-tailed deer herd. Wildlife Society Bulletin, pp.186-192.

Ward, A.I., Finney, J.K., Beatham, S.E., Delahay, R.J., Robertson, P.A. en Cowan, D.P., 2016. Exclusions for resolving urban badger damage problems: outcomes and consequences. Peer], 4, p.e2579.

Ward, A.I., Pietravalle, S., Cowan, D.P. en Delahay, R.J., 2008. Deterrent or dinner bell? Alteration of badger activity and feeding at baited plots using ultrasonic and water jet devices. Applied Animal Behaviour Science, 115(3), pp.221-232.

Watkins, N., Davies, V., Hickling, G. en Trought, M., 2000. Bird Behaviour in Vineyards: A Review.

Whitford, P., 2009. Successful use of alarm and alert calls to reduce emerging crop damage by resident canada geese near horicon marsh, wisconsin. In 2009 Bird Strike North America Conference p. 1.

Whitford, P., 2008, January. Successful use of alarm and alert calls to reduce emerging crop damage by resident Canada geese near Horicon Marsh, Wisconsin. In 2009 Bird Strike North America Conference (p. 1). 
Whittingham, M.J. en Evans, K.L., 2004. The effects of habitat structure on predation risk of birds in agricultural landscapes. Ibis, 146(s2), pp.210-220.

Wright, S.E., Dolbeer, R.A. en Montoney, A.J., 1998. Deer on airports: an accident waiting to happen. Yasué, M., Quinn, J.L. en Cresswell, W., 2003. Multiple effects of weather on the starvation and predation risk trade-off in choice of feeding location in Redshanks. Functional Ecology, 17(6), pp.727-736.

Yokoyama, H. en Nakamura, K., 1993. Aversive response of tree sparrows Passer montanus to distress call and the sound of paper flag. Applied Entomology and Zoology, 28(3), pp.359-370.

York, D.L., Cummings, J.L., Engeman, R.M. en Wedemeyer, K.L., 2000. Hazing and movements of Canada geese near Elmendorf Air Force Base in Anchorage, Alaska. International biodeterioration en biodegradation, 45(3), pp.103-110. 
Wageningen Environmental Research Postbus 47

6700 AA Wageningen

T 0317480700

www.wur.nl/environmental-research

Wageningen Environmental Research Rapport 2888

ISSN 1566-7197
De missie van Wageningen University \& Research is 'To explore the potential of nature to improve the quality of life'. Binnen Wageningen University \& Research bundelen Wageningen University en gespecialiseerde onderzoeksinstituten van Stichting Wageningen Research hun krachten om bij te dragen aan de oplossing van belangrijke vragen in het domein van gezonde voeding en leefomgeving. Met ongeveer 30 vestigingen, 5.000 medewerkers en 10.000 studenten behoort Wageningen University \& Research wereldwijd tot de aansprekende kennisinstellingen binnen haar domein. De integrale benadering van de vraagstukken en de samenwerking tussen verschillende disciplines vormen het hart van de unieke Wageningen aanpak. 



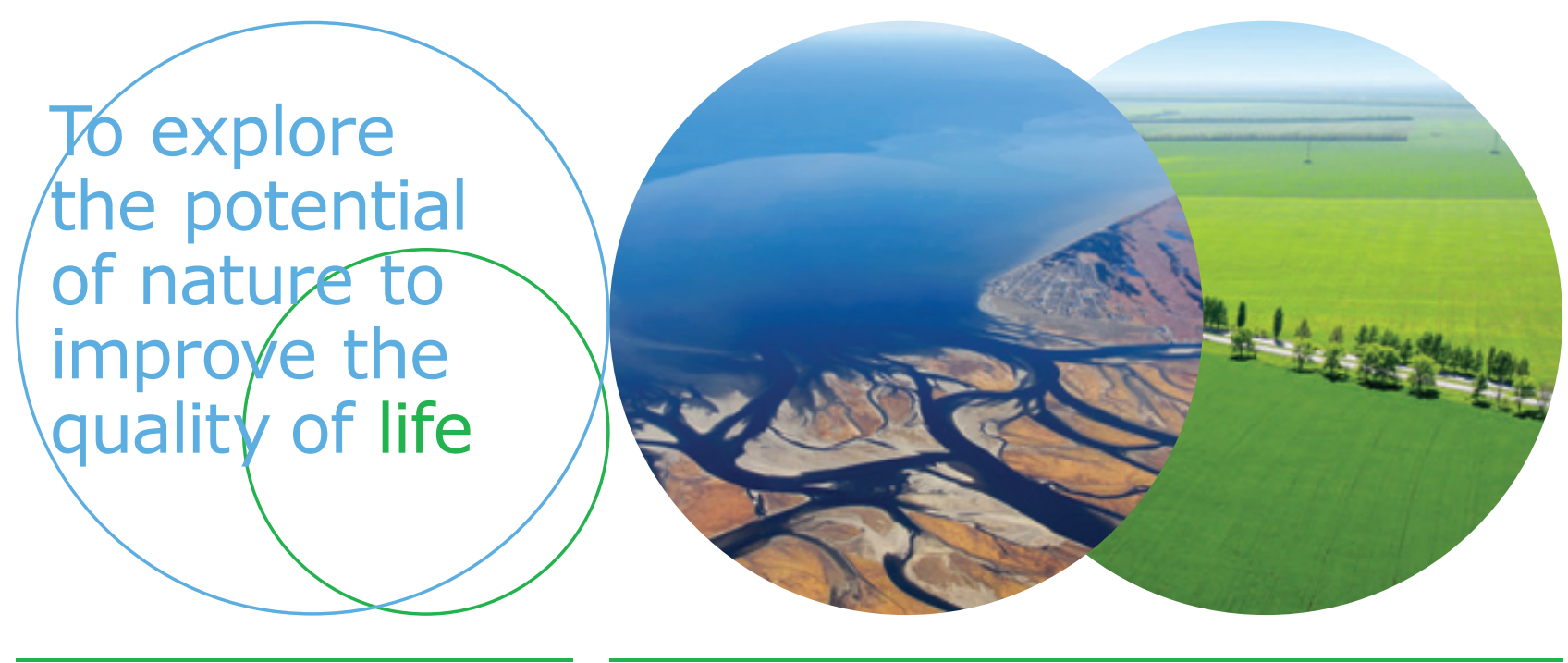

Wageningen Environmental Research Postbus 47

$6700 \mathrm{AB}$ Wageningen

T 317480700

www.wur.nl/environmental-research

Rapport 2888

ISSN 1566-7197
De missie van Wageningen University \& Research is 'To explore the potential of nature to improve the quality of life'. Binnen Wageningen University \& Research bundelen Wageningen University en gespecialiseerde onderzoeksinstituten van Stichting Wageningen Research hun krachten om bij te dragen aan de oplossing van belangrijke vragen in het domein van gezonde voeding en leefomgeving. Met ongeveer 30 vestigingen, 5.000 medewerkers en 10.000 studenten behoort Wageningen University \& Research wereldwijd tot de aansprekende kennisinstellingen binnen haar domein. De integrale benadering van de vraagstukken en de samenwerking tussen verschillende disciplines vormen het hart van de unieke Wageningen aanpak. 